\title{
Living Into A Vision: A Case Study of Riverview Park Reformed Church.
}

A Doctor of Ministry Thesis Submitted

In Partial Fulfillment of the Requirements for the

Doctor of Ministry Degree At Western Theological Seminary,

Holland, Michigan

\section{By \\ Rodney Dale Veldhuizen, M. Div.; M.A.}




\section{INDEX}

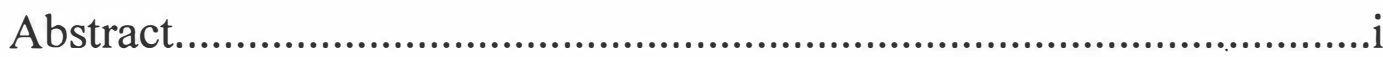

Acknowledgements .......................................................................... ii

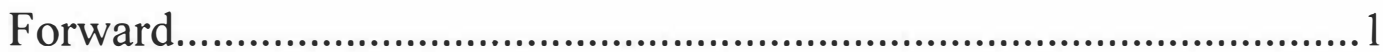

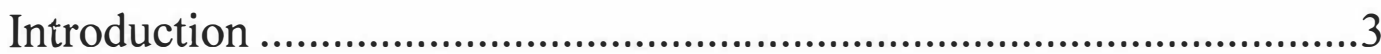

Chapter One.......................................................................................13

Historical Background Of Riverview Park Reformed Church

Chapter Two

History and Processes: Identifying the Narratives of Harm

Chapter Three

History and Processes: Identifying the Narratives of Hope

Chapter Four.

Contraindications Of Harm and Health

Chapter Five

The Refocusing Process As a Tool of Renewal

Chapter Six

My Journey

Chapter Seven.....

130

Identifying Narratives of Harm and Narratives of Hope: In My

Own History and Life

Chapter Eight 145

Summary and Conclusion

Bibliography 158

Appendix \#1

Definition of Terms

Appendix \#2 
Interview Questions Used in Church History

Appendix \#3

170

Church Attitude Questionnaire

Appendix \#4

Riverview Park Reformed Church Vision Statement

Appendix \#5

175

Strategic Plan 2000

Appendix \#6

194

Comparison of the Interim Pastor and the Refocus Process

Appendix \#7

The Four "R's" of Refocusing 


\section{ACKNOWLEDGEMENTS}

When I returned to the classroom in 1997 I made a conscious decision to pursue a second Master's Degree rather than a Doctor of Ministry degree. My reasoning is that I wanted a degree that had "market value" and should I decide to change career paths I could easily move into a professional counseling position. Upon graduation in 2000 from North American Baptist Seminary in Sioux Falls, SD with a degree in Marriage and Family Therapy I fully intended to never pursue any further degree.

Now with the Doctor of Ministry program completed it is time to reflect and give thanks for the journey that has been taken. This project was not completed in a vacuum, nor could it have been accomplished without the support and encouragement of my wife of 27 years, Deb. Deb is the one who encouraged me when I did not want to read any more, who supported me when I had to be gone for two weeks annually. She even supported me when my residency requirement meant we would not be able to celebrate our $25^{\text {th }}$ Wedding Anniversary on the date. (She did fly out to join me in Michigan so we could enjoy a leisurely drive back to South Dakota at the end of that week.) Without Deb, I know this project would have never been accomplished nor would I be who I am or where I am today without her.

I would also be remiss if I did not mention the generous people at Riverview Park Reformed Church who granted me the time needed to not only do the academic work on this Doctor of Ministry program, but also served as the testing ground for many of my hypotheses along the way. They also graciously allowed me to research their past, ask questions about their involvement and generally assisted me in any way possible to 
accomplish the goal of completing not only this thesis but also the Doctor of Ministry Degree.

This learning did not occur in a vacuum as my colleagues in ministry who also gave me feedback and support along the way surrounded me. Even more directly were my Doctor of Ministry Committee members, Dr. Thomas Boogaart and Dr. Jaco Hamman. Not only did these men assist me in developing and designing the learning units, but also they both read many, many pages of papers and draft after draft of this project. These men were more than just professors giving assignments and reading papers, they became colleagues in learning with me, challenging me when I needed, and providing the guidance necessary to assist me. To these two men, along with the rest of the faculty of Western Theological Seminary I want to say thanks for the support and encouragement.

Finally, there were the friends who helped edit this paper. After all my years of school, the one area I have yet to begin to understand is English grammar. Thanks go to Lilah Gillis who did some of the early editing, making sure my actually made some sense, and giving me that journalistic perspective only a former newspaper writer could. I also want to thank Christi O Connell-Ekroth who did the final edit and grammar check. Christi made the sentences and thoughts I strove to convey much more understandable.

As with any other list of people and words of thanks I am certain to have over looked someone who should have been mentioned. If I were to try and be comprehensive the list and the thanks would double the size of this project. Let me conclude with the acknowledgement that I did not arrive at my conclusions alone, I owe a debt to authors and thinkers, along with professional and pastoral contacts through out my life. The 
greatest thanks must go to the God who has been faithful to me throughout my life and as I look back has given me more than I could ever hope or even imagine possible in my life. To God be the glory! 


\section{FOREWARD}

One of the challenges in writing up this thesis is the issue of language. This is not a reference to inclusive language as there are sufficient guides and suggestions available to the writer to assist in the development of those aspects today. The challenge is the use of the word church! Such a simple term that pastors and laypeople use all the time, but when attempting to be precise, what does the writer mean by the word church? In some cases it references the local congregation that meets in a building in a particular location. At other times the word means a building where a congregation meets. At still other times it refers to the worldwide body of believers in Jesus Christ. In an effort at uniformity, and to assist the reader I have included Appendix \#1 that gives explanation to the various terms and titles that are both common to the language of ecclesiology and those that are specific to the Reformed Church In America, the denomination that the Riverview Park Reformed Church is a part of and the denomination that holds my ordination.

While the preceding paragraph helps clarify my language, I found confusion would still be present in looking at the written documents pertaining to the Riverview Park Reformed Church, the congregation I use as the basis of this case study. In those written documents the word church is used in multiple contexts and carries the many and various meanings. In those situations, as they are historical documents, I will need to ask you, the reader, to examine the context to determine its meaning. Where my analysis requires reference to the local expression of the body of Christ in a particular place, I will use one of two terms: 1) "local church" to refer to that community, or 2) "congregation" 
to refer to what is commonly called church. It is my desire that this will enable the reader to understand the reference without confusion as to which version of church is intended. 


\section{Introduction}

Local church renewal and revitalization are a growing concern for the mainline denominations in the United States, and in particular for the Reformed Church in America (RCA). We are and have been in decline. This decline has made us anxious and has absorbed all of our attention. For the past two years I have been working on revitalization in the RCA congregation in Yankton, South Dakota, Riverview Park Reformed Church (RPRC). I have pursued this goal in a very particular way. I have worked with the congregation to help it come to a deeper understanding of its own history by identifying, what I have labeled, narratives of harm and lines of hope. I have found this work to be essential to the task of revitalization.

\section{Narratives of Harm}

"Narratives of harm" is not a well-known phrase as it originates with Christie Cozad Neuger, a pastoral theologian. She defines the term this way:

I want to make the case that the primary "story we live by," the one within which we make life decisions in this culture, is a narrative that normalizes and even explicitly trains men to harm women in intimate relationships (especially when men feel threatened) and women find ways to interpret that violence so that they remain in it. ${ }^{1}$

I have taken Neuger's term and broadened it to include all the stories of abusive behavior in a community. I have found that uncovering these narratives of harm is very challenging for they are often hidden and unspoken. Although these narratives of harm remain hidden and unspoken, their power and destructive ability are not diminished.

\footnotetext{
'Cozad Neuger, Christie, "Narratives of Harm: Setting the Developmental Context For Intimate Violence"; In Her Own Time: Women and Developmental Issues in Pastoral Care, Jeanne Stevenson Moessner, ed.; Fortress Press, Minneapolis, MN 2000. p. 70.
} 
When these narratives of harm are brought out into the open, they begin to lose their power. When they are brought out into the open, the larger and truer narrative of a congregation is told. When this large narrative is told, the congregation begins to find renewed hope and vigor.

\section{Lines of hope}

While it is important to identify the narratives of harm that have besieged a community, that is not the whole story. Operating alongside and even at times in conjunction with the narratives of harm is what I call "lines of hope." These are stories told by communities that reflect their ability to face and overcome obstacles. While there are no common names for them, there are many of these stories held in the collective memory of a community and ready to be told. One form of this story is the "rags to riches" story, reflecting the victory of a person over poverty or adversity. Another form is what some people would simply label "history," accounts of key events in the life of the community. One community I served, Eddyville, was proud to tell me that during Prohibition one bar in town always had alcohol. That is until the day the "revenuers" drank from the "wrong" cistern! To understand this community, you need to know this story, to know how they took pride in their independence, as well as a sense of lawlessness. With its roots in the frontier, the residents of Eddyville had a certain disdain for authority that enabled them to survive through adversity and lean times. While not prosperous, the community had a gritty determination that allowed them to stay alive through floods and government decrees. This gritty determination showed up again in 1993 when the river threatened to flood the town. Two men with bulldozers ignored 
engineer's warnings to quit and reinforced the levee to save the town from flooding. While Eddyville was not prosperous, they were in more ways than one, family. That pride and sense of belonging had to be understood by anyone who hoped to make a difference or bring change to that community.

To understand the community where I currently reside, it is important to know that it once served as the territorial capital for the Dakota Territory. Yankton still sees itself as the gateway to the Dakotas. In the 1800's Lewis and Clark camped near the city; General Custer spent a winter in it; and for many years Yankton was the most influential city in the territory. Times have changed, and the Missouri River is no longer the highway of commerce it was. When you look at Yankton, this sense of loss of place and pride has to be taken into account when dealing with the community.

While a lot of people would dismiss stories like these as just interesting tidbits of history, the reality is that they begin to reveal the rich legacy of these two communities. I am arguing that in order to do effective ministry in communities, it is vital to understand their narratives of harm and hope. In both communities, I had to understand that I was an "outsider" stepping into an established order and if I wanted to make a difference I needed to learn what the community stood for. I also needed to know that both communities had once been places of considerable influence, but no longer could claim that title. Just as a community carries stories of harm and hope, the same is true for a local congregation. Thus questions that might be asked of a congregation include: How has God been at work in their lives? Do they see the glory days as past? Or is God preparing them for something greater? 
It is important for a leader to know the stories of his or her community if he or she wants to foster growth. One congregation with which I am acquainted was on the verge of being closed by its Classis until one laywoman took charge and began to work to save her congregation. During my visit there in the early 1990's, it was experiencing an average attendance of nearly 300 people in four worship services, conducted in three different languages. Anyone wanting to serve this congregation effectively would have to know this story. Stories like this one provide the clues and suggest ways to help a congregation recover its vitality. Or as an old adage that I learned years ago says: "Root your changes in the best of a congregation's history."

\section{Case study: Riverview Park Reformed Church}

To assist in understanding how these narratives of harm and hope converge in a community, I am presenting the case study of the Riverview Park Reformed Church (RPRC), where I am currently the pastor. Like any congregation, RPRC in Yankton, South Dakota, has its narratives of harm and hope. The congregation has been gracious enough to accept the challenge and explore these narratives with me. In the study of the life and history of the congregation ${ }^{2}$ we found that narratives of harm and hope were woven together. Unlike the B-Movie Western where the good guys wore white hats and the bad guys wore black hats, in the history of this congregation, as well as many other congregations, there is a lot of gray! As we took time to unpack the story of this congregation, the shades of gray began to emerge and we began to appreciate its rich and

\footnotetext{
${ }^{2}$ This study was done as part of a renewal process known as Refocusing. This process will be further explained in the next paragraphs.
} 
complex history. In the process together we have begun to understand more deeply the dynamics of revitalization in our congregation.

Identifying narratives of harm and hope helped this congregation understand itself better but it also helped create a sense of urgency. While there are many artificial means to create a sense of urgency, the best tool I have discovered at this point is enabling congregations to understand their own history. This history is much more than recovering stories, it also involves asking the question, where is God at work and where has God been at work in the life of this congregation? When that question is asked and honestly answered, it provides an opportunity for the congregation to then ask the question, what would God have this congregation do next? It is in understanding the unique shaping of an individual congregation that renewal or change finally becomes possible. When a congregation understands God's unique shaping in their life together that a sense of urgency to change begins to take shape. Lacking a sense of urgency, at the very minimum, the leadership of the congregation needs to understand that it cannot continue to operate the way it always had.

This case study will show clearly that the motivation for change was not driven by forces outside, but by forces inside the congregation. Motivation for change took root when lay people felt the need for change and they set the agenda. It is my conviction that unless the congregation feels the urgency for change, no amount of urging from the outside will bring about the needed change.

I soon discovered that leading a congregation to tell its narratives of harm and hope meant that I personally had to tell my narratives of harm and hope. Personal renewal precedes corporate renewal. This is the mantra of the Refocusing process now 
being widely used in the RCA. For those who are unfamiliar with Refocusing, let me borrow a brief description from the first years leader's manual:

Refocusing is a two-year revitalization process for a local church which brings personal renewal to the lives of leaders and the creation of a five-year plan to reach the community and beyond. Refocusing produces harvest-focused churches led by church leaders committed to raising up more and better disciples and churches. ${ }^{3}$

When pastors and key lay leaders discover God's personal plan for their lives, they can lead the congregation to discover God plan. In my own course of my study, I have discovered the truth of this. My own personal journey has dramatically shaped who I am as a pastor and has dramatically influenced my capacity to lead. I cannot really hear my congregation's narratives of harm and hope, if I am not listening to my own narratives.

\section{Systems Theory}

I have been a pastor for nearly 25 years. After 16 years of ministry, I chose to pursue a second Master's degree, this time in the field of Marriage and Family Therapy. Consequently I approach the world of the Church and congregations through the lens of Systems Theory. Any reference to therapy or counseling should be seen through that lens. While family therapy has many different schools of thought and approaches in working with individuals and families, this approach is characterized by:

[The idea] that a family system should be seen as more than a collection of people, and that therapists should focus on interaction among family members rather than on individual qualities. ${ }^{4}$

\footnotetext{
${ }^{3}$ Walling Terry, Refocusing Network System, Year I; Focusing Leaders Network Facilitator Manual; Church Resource Ministries; Anaheim, CA.; 1999; Introduction/2.

${ }^{4}$ Nichols, Michael P. and Schwartz, Richard C; Family Therapy, Concepts and Methods. Allyn and Bacon, Boston, MA. 1995. p. 89.
} 
For an academic understanding this quote serves quite well. My understanding of systems is explained using the metaphor of a child's mobile. The mobile is a delicately balanced system of strings, wires, and objects. When one part of the mobile is moved, it sets the whole mobile in motion. That is a picture of systems theory. No person is an island and any one person's action can and will affect others within that same system. These systems can be families, churches, schools, or social clubs. Just as families are seen as more than a collection of people, so congregations and institutions can be analyzed based on the interactions between the members, and not just on the individual qualities of the people involved. When I look at the history of the RPRC, I am focusing not on the individuals involved, but on the interactions between the many members of the system. While the congregations and the denomination are both made up of individuals, there is also a great deal of understanding that can develop from looking at the interaction within the system and between the different parts.

What also needs to be kept in mind is that while the individuals remain responsible for their actions, at other levels they are put into roles and expected to fulfill expectations based on those roles. Once the would-be-helper understands the system of interactions that are taking place, the helper can then encourage a healthier pattern of interaction. When the interaction changes, it also changes the system and that is the goal that I bring to this work of local church renewal and revitalization.

Looking at this case study through the eyes of systems theory, I begin to see how the congregation and its leaders developed interactions that hindered or sometimes helped each other. This approach has also enabled me to work with couples and families in a manner that does not affix blame to any one person in the family. In my best moments I 
can do that easily. While it is becoming second nature in therapy situations, I am not always so gracious in other areas of my life. In my own life, as I examine my own unique shaping, I see how the systems around me, both my immediate family and the culture I grew up in, influenced who I am today. It is in this light that I want to examine the process of local church renewal and revitalization, on a congregational, pastoral, and finally a denominational level.

\section{Outline of the Project}

In the first chapter of this project, I offer a history or RPRC gleaned from Consistory minutes, formal interviews with nine families, ${ }^{5}$ and the process of hearing the church's story over the past seven years as its pastor. In the second chapter, I will provide an analysis of this history, identifying the narratives of harm as they occurred in the history of the congregation, and identifying those behaviors and situations that would lead to significant problems in the life of the congregation. In the third chapter, I identify the lines of hope that sustained the congregation. In the fourth chapter, I underscore the complexity of the process that unfolded here and suggest that such a process is potentially present in every congregation. Chapter Four details those contraindications and the intermixing of harm and health in the life of this congregation. What I found is it is often too simplistic to label a situation as a narrative of harm or hope.

\footnotetext{
${ }^{5}$ The families chosen were three who had remained in the church after the church split, three who had left and have since returned, and three who had left and have not returned. Additionally there have been numerous informal conversations that contribute to my sense of the flow of the history reported here.
} 
In the fifth chapter, I will compare the process used by the Second Interim following the departure of a long-term pastor and the refocusing process alluded to earlier.

The sixth chapter marks a shift and I begin to identify my own narratives of harm and hope as I present a brief autobiography. The seventh chapter is where I identify my own journey of self-understanding, and how this unique shaping prepared me to listen to and to lead this congregation. This reflects my growing awareness that unless leaders understand their unique shaping and how God has prepared them for ministry, congregational renewal will not be sustainable. For ministry to be fruitful, the pastor and the congregation have to understand each other, to work together, and to define together the mission of the congregation. Tension often develops when pastor and congregation have not listened carefully enough to each other's narrative and lack the understanding to overcome division.

In the seventh chapter, I will compare the process used by the Second Interim following the departure of a long-term pastor and the refocusing process alluded to earlier. In chapter eight I will evaluate the denominations plans for revitalization based on what I have learned at RPRC. As I move into this arena, I have fewer answers than questions. I will probe what might be the denominational narrative of harm that could subvert revitalization and what are the lines of hope that might enable an entire denomination to experience revitalization.

This case study is not presented as a step-by-step or one-size-fits-all model for congregational revitalization; rather it is the story, followed by analysis, of how one particular congregation became a more united and vital congregation. The story of the 
church is yet unfinished, and the telling of it is colored by the fact that I am the current pastor. The case study suggests a process that other congregation can follow. If I were pressed to identify a key to this process, it would be telling the story of the congregation. For a deeper understanding of the congregation's particular story is an essential piece in revitalizing the congregation.

The congregation's need for a deeper understanding of their history reminds me of this anecdote. An economist addressed a group of business people about the recession. She tacked up a big sheet of white paper. Placing a black spot on the paper with her pencil, she asked a man in the front row what he saw. The man replied promptly, "A black spot." The speaker asked every person the same question, and each replied, "A black spot." With calm and deliberate emphasis the speaker said, "Yes, there is a little black spot, but none of you mentioned the big sheet of white paper. And that's my speech." A congregation that has become anxious and focused on the immediate and pressing needs of membership decline, the black spot, and consequently does not take the time to know the larger context, the big sheet of white paper. When a congregation begins to understand its own unique history, and how God has been at work in its life, that the congregation stops staring at the little black dot and begins to see the white space all around it. It is in the space that a person and a congregation discover new possibilities and new hope for renewal under the guidance of the grace of God. 


\section{Chapter One}

\section{Historical Background Of Riverview Park Reformed Church}

To write this historical background I depended on multiple sources, but the two major sources were the Minutes of the Consistory of the Riverview Park Reformed Church that are conveniently stored in the safe in the RPRC office, and interviews. I interviewed three groups of people. First, I sought out a sample from among those who had remained in the congregation throughout the last twelve to fifteen years. The second group included those who had been members, left for a time and have since returned to the congregation. The final group consisted of those who had left RPRC somewhere within that time frame and had not returned. The other oral sources for this project are conversations with members and previous members that occurred in various contexts. Interviews and conversations aided my research, but I have also accessed minutes from Dakota Classis records, and records that remain in the RPRC of fice in various places and files. The final sources are the two "official" histories of the congregation written for the $25^{\text {th }}$ and $30^{\text {th }}$ Anniversary celebrations.

Riverview Park Reformed Church (RPRC) traces its origins to a survey conducted by the Board of North American Missions and the Classis of Dakota indicating that Yankton would be a good place to establish a Reformed Church. Originally named Yankton Reformed Church, the first service was held in February 1962. When the minutes of the church indicate that the first worship service was held here in 1962, it refers to the fact that the building was established before the congregation. In line with 
established practice of the late 1950's and early 1960's, the site to establish a new congregation was chosen based on its proximity to a school (in this case, in 1960 Yankton High School was less than a block away and also Yankton College was within walking distance) and its location in a growing community on a major street. (The church building sits on a corner lot fronted by two major routes through the city).

With the building in place and a parsonage built, with funding provided by both the Regional Synod of the Far West and the Dakota Classis, the only component in this plan that was lacking was a pastor, and so the first pastor was sent to "build a local church." Given that the new congregation was dependent on financial support from the outside, the pastor was instructed to develop this congregation quickly so that they would assume the debt on this building.

Building a congregation did not prove to be an easy task as the Minutes of Consistory dated November 24, 1962, read:

Motion was made and supported that because of an unchristian attitude and relations with other members of the church __ to be relieved of __ duties as a Sunday School teacher. Motion carried unanimously. Motion made supported that a consistory meeting be called on Friday evening of Nov. 30, 1962, for the purpose of creating a better understanding among the members of consistory. Motion was passed unanimously. ${ }^{6}$

The minutes of the November $30^{\text {th }}$ meeting indicate that the vision of the congregation had not been explored previously, for these minutes record the following motion, which seems to have served as a "Vision Statement" for this young congregation, as well as a way to deal with the issue surrounding the problematic Sunday School teacher:

It is hereby moved that Riverview Park Reformed Church of Yankton has been established with the intention of becoming a church in this area, therefore the program of the said church ought to be one that is acceptable to people of all ages, races, nationalistic background and previous denominational affiliation. We

\footnotetext{
${ }^{6}$ Minutes of Consistory of the Riverview Park Reformed Church, Nov. 24, 1962.
} 
recommend that a school of educational instruction be begun for all teachers of the church. Furthermore, it is expected that teachers will be present at these meetings, that they will use materials and employ methods that are acceptable to the Consistory and that they will present the person of Jesus Christ as a living reality. While we recognize that the church of Jesus Christ is a living reality, we are aware that it is an imperfect institution. It is nevertheless, the body of Christ. As members of the church we are to be followers of Christ and regard fellow Christians as equal members of His body. Recognizing the Biblical concept of the church as a fellowship of believing people we recommend that our church provide the opportunity of Christian fellowship as much as possible. ${ }^{7}$

While the statement had many high and lofty goals, evidently the men gathered that night decided that the idea of fellowship was too important to wait. One of them was commissioned to find an open night at the local bowling alley for the men to bowl together. ${ }^{8}$

\section{Unexpected Outcome from Conflict}

While the pastor and leadership dealt with one issue, they found themselves dealing with unexpected outcomes from this situation, a loss of membership. The consistory minutes dated January 29,1963 , indicate two men who had previously been elected to serve on the consistory were deposed, and it is noted neither they nor their families had been present in worship since the $25^{\text {th }}$ of November. ${ }^{9}$ The congregation that began with 29 charter members was now declining in membership instead of growing as had been hoped.

The Classis also noted this declining membership and attendant conflict. The minutes of June 3, 1963, indicate the pastor and Consistory discussed the lack of

\footnotetext{
${ }^{7}$ Ibid., November 30, 1962.

${ }^{8}$ Ibid., November 30, 1962.

${ }^{9}$ Ibid., January 29, 1963.
} 
growth. ${ }^{10}$ The minutes indicate the response from both pastor and leadership was that effort was being put forth, but the community already had a lot of congregations (today, Yankton has at least 26 Protestant Churches, and two large Catholic parishes) and people were already faithful to those established congregations. The minutes indicate that the visiting team was willing to allow this lack of visible growth to continue at least until the Fall Classis meeting. Unfortunately, the situation did not improve much; the minutes from October 1963 again mention the issue of the lack of congregational growth:

The matter of growth of our church was considered. It was agreed that the reason we have difficulty getting people to come to our church is that the community has a fear that joining our church will obligate them to pay for this expensive property. It was decided that we would inform people that we are not obligated to pay for the property until the congregation is of sufficient size to do it. ${ }^{11}$

This decision did not have much impact on prospective members. The annual constitutional inquiry and state of religion report was included in the Consistory minutes and notes:

Our worship services have been attended by an approximately 16-18 adults and an equal number of children... We feel that that all our members are receiving spiritual blessings by worshipping together. They seek to be faithful both in attendance and the work of the church. We the Consistory feel that Rev. should be commended on the very fine work that he had done and continues to do, both in the church and community. We feel that through his contacts and visitations he is constantly working for the upbuilding for the faithful membership of this church. We would also like to note that in this community only a very small percentage of the people are not affiliated with some church. Considering these conditions, it will be difficult to notice rapid growth here. ${ }^{12}$

The Dakota Classis supervisors did not share the assessment of the leadership of RPRC. The Consistory minutes dated April 22, 1964, record that the pastor had received a letter from the Church Extension Committee of Dakota Classis. In this letter, the

\footnotetext{
${ }^{10}$ Ibid., June 3, 1963.

${ }^{11}$ Ibid., October 24, 1963.

${ }^{12}$ Ibid., February 18, 1964.
} 
committee charged the pastor "had been uncertain as a pastor in the area of purpose and goal." ${ }^{, 13}$ From the minutes it is clear that the local church leadership did not concur with the Classis assessment, and one woman who was present during this pastor's brief tenure remembered him as a man who was doing his best, but was removed by the Classis. While the Consistory indicated their willingness to argue their pastor's case before the Classis, the pastor chose to abide by the decision of the Classis. He informed the leaders that he had already been looking for a new place of ministry and was not leaving due to conflict with the congregation, but only at the recommendation of the Church Extension Committee.

\section{First Interim Pastor}

While the first pastor would only serve two and a half years, the congregation did not remain in neutral. A search committee was immediately formed and an interim or "Supply Pastor" was brought in from Sioux Falls to assure the continuation of Sunday Worship in this fledgling congregation. Evidently during this interim period the congregation sought to bolster its financial situation by contracting with a "nursery school" to use its facilities. The minutes from December 29, 1964, indicates, "One hundred dollars is to be the rent for the nursery school."

\section{Pastor \#2}

The second pastor would begin working at RPRC in January 1965, and a note from the minutes of March 2, 1965, indicates that the Consistory and pastor were

\footnotetext{
${ }^{13}$ Ibid., April 22, 1964.

${ }^{14}$ Ibid., December 29, 1964.
} 
concerned with the need for growth. Questions were asked about canvassing the congregation for the purpose of extension work. ${ }^{15}$ This pastor also sought to increase the visibility and outreach of this congregation by establishing a Boy Scout Troop (which continues today), with the pastor serving as its first Scout Master. ${ }^{16}$ Very little else is found of note on this pastor, except some personal recollections. One long-term member who joined during this time recalls asking this pastor how many people belonged to the congregation, and never really getting a solid answer from him. The member said that at the time his family joined the congregation there were only seven other families who belonged to RPRC. It must have been a tribute to this pastor that RPRC continued during this time and would survive, growing slowly.

One constant during this time was the issue of finances, or the lack of them. Minutes of the congregation indicate that a special Congregational Meeting was called on October 8,1967 , to discuss the possibility of the pastor taking on the additional responsibility of serving a Methodist congregation located just across the border into Nebraska. While there is no record as to why this was suggested, the most likely reason was a desire to make the congregation more self-supporting. The congregation was not in favor of sharing their pastor in this manner and voted 21-3 against serving the second congregation. ${ }^{17}$

The consistory and pastor, along with the Classis, continued to seek to improve the quality of ministry and the quantity of the membership through various means. A special consistory meeting was called on October 22,1968 to examine the results of a

\footnotetext{
${ }^{15}$ Ibid., March 2, 1965.

${ }^{16}$ The Scout Troop represents a significant part of the ministry of this church and how it has sought to do ministry in this community. I will be revisiting this issue at a later time.

${ }^{17}$ Ibid., October 8, 1967.
} 
self-study. While no conclusions or even any of the discussion was included, the minutes record that they would need more time "in regard to our problems in Yankton due to the many activities in the Pastor's work and organizing the committee." 18 Among the problems in Yankton must have been complaints. There was another special Consistory meeting held that year on December 19, 1968, which records:

Motion made and carried that Rev. contact the Church Extension Committee to meet with the Yankton Consistory for their next meeting. Motion made and carried to publish in the bulletin this statement, 'Those who have complaints about consistory actions to approach the whole Consistory on the subject, or at a regular meeting or one called for that purpose." ${ }^{, 19}$

Confirming this item in the minutes of RPRC was a conversation with a former long-term member who had previously moved out of state. That member said a group of people within the congregation had criticized every pastor who had served the congregation, as these first two Pastors appear to have discovered.

Additional minutes record the consistory asking the Classis for additional support as the costs of maintaining a resident pastor increased. ${ }^{20}$ The record of the December 1969 Congregational meeting indicated that the Congregation needed approximately $\$ 180.00$ in offerings weekly to meet their budget. That takes into account rental from the Nursery School and support from both Classis and the General Program Council. ${ }^{21}$

Prior to the departure of the second pastor, RPRC took the necessary steps to become incorporated according to South Dakota law in January 1970. During that same time, the minutes note the upcoming departure of the installed pastor. ${ }^{22}$ The matter of incorporation would not be settled immediately, as the minutes record that a special

\footnotetext{
${ }^{18}$ Ibid., October 22, 1968.

${ }^{19}$ Ibid., December 12, 1968.

${ }^{20}$ Ibid., December 12, 1967 \& May 26, 1969.

${ }^{21}$ Minutes from Annual Congregational Meeting, December 9, 1969.

${ }^{22}$ Minutes of Consistory, January 6, 1970.
} 
Congregational Meeting was held on March 7, 1970, to consider extending a call ${ }^{23}$ to a pastor, as well as to consider changing the name of RPRC and incorporation. ${ }^{24}$ The man who was extended that call accepted, becoming RPRC's third resident pastor, moving to Yankton in April 1970.

\section{Pastor \#3}

Following the installation of Pastor \#3 the congregation moved ahead slowly. The minutes reflect routine business until the February 8, 1971 minutes record that one of the elders "reported on the formation of small groups as the result of Lay Witness Mission. A total of 28 members are interested. Also, men's breakfast being planned. ${ }^{, 25}$ When the Lay Witness Mission was held or who led it is not recorded anywhere in the Consistory minutes, or in any of the congregation's other documents. What it indicates is that the pastor and the congregational leadership were looking to the tools and opportunities available to them in their efforts to build up the membership.

At that same meeting the pastor's report notes:

Rev._ reported that the Pastor's class was fruitful and rewarding. Calling program has suffered due to heavy schedule of other programs such as Lay Witness Mission. Opportunities to visit patients of Reformed Church background from other areas at both hospitals. Pastor and wife visiting schools to show slides of Indian Mission work. Newsletter takes up much time. Considerable personal counseling. Have received requests from Platte Reformed and Gayville Methodist for our members to come and speak about Lay Witness Mission. ${ }^{26}$

This report indicates that the pastor and congregation were active in the Lay Witness movement, which during the 1970's was an active congregational renewal program. The

\footnotetext{
${ }^{23}$ A call is an ecclesiastical term used by some protestant churches to describe a contractual agreement between a clergy person and a local congregation.

${ }^{24}$ Ibid., March 7, 1970.

${ }^{25}$ Ibid., February 8, 1971.

${ }^{26}$ Ibid., February 8, 1971.
} 
program empowered lay people to share their own story of their life with Christ in various local churches around them.

While solid numbers are difficult to find during this time in the life of RPRC, the minutes of March 8, 1971, give a synopsis of the Annual Consistorial report listing the numerical figures: "As of 1-1-71 Church families 34. Active Communicants 61 . Inactive communicants 6. Baptized non-communicants 37. Total Baptized membership 104." RPRC now at least had effectively broken the " 100 " barrier, and from the general sense of the minutes, the congregation is growing. In May the minutes indicate the Consistory is investigating purchasing used pews from a church facility in Northwest Iowa, as well as proceeding with plans to expand the parking lot. ${ }^{27}$

With a growing congregation, the Classis approached the congregation about assuming the remaining debt on the building in August 1971. The consistory apparently did not feel ready to assume the debt with a 15 -year repayment plan and requested that they not be asked to assume this responsibility until $1974 !^{28}$ While the consistory attempted to defer the financial responsibility, it is also noted that they had been asked to participate in the Faith and Action program of the Institute of Church renewal and that the consistory was interested in pursuing this opportunity. ${ }^{29}$

While the congregation was participating in the Lay Witness movement, the teens of RPRC were seeking opportunities in their own community. The minutes of October 1971 report the Consistory approved the Youth Group holding a "Coffee House" within the building that would be called "The Place." ${ }^{30}$ The description indicates the youth were

\footnotetext{
${ }^{27}$ Ibid., May 10, 1971.

${ }^{28}$ Ibid., August 2, 1971.

${ }^{29}$ Ibid., August 2, 1971.

${ }^{30}$ Ibid., October 11, 1971.
} 
planning an outreach to the peers. While it is difficult to know how many years The Place would be in operation, its presence indicates a willingness to allow a broader approach to ministry taking place outside the realm of the pastor and consistory. The youth group must have been an active and expanding group as the minutes from January 1973 note that the pastor and elders were to look for a student youth worker. ${ }^{31}$

While the congregation desired to postpone assumption of the $\$ 50,000$ loan until 1974, the Classis must not have concurred; the minutes of February 1972 indicate concern with a deficit in funds, and at the end of the meeting, a note was added authorizing someone to sign the repayment papers. ${ }^{32}$ While there is no direct connection between assuming the repayment of the loan and the lack of funds, in May the Consistory discussed the possibility of starting a non-profit nursery school and day care center to begin in September $1972 .^{33}$ (A less mercenary view would see the leadership seeking to develop a more consistent outreach to the community, although there is no active recollection of this process among the members of the congregation today.) Looking through succeeding minutes, this investigation must have returned negative results, as there is no record or any memory of RPRC ever owning or operating a day care or nursery school. The nursery school that began in 1964 would continue to operate on the property until 1998. At that time the owner purchased a building to house the preschool, ending a long-term relationship with the RPRC.

Once the congregation assumed the debt repayment, the consistory was regularly concerned about how to deal with paying this off. The repayment schedule was on the

\footnotetext{
${ }^{31}$ Ibid., January 8, 1973.

32 Ibid., February 14, 1972.

${ }^{33}$ Ibid., May 15, 1972.
} 
agenda of the 1972 Congregational meeting. ${ }^{34}$ At the March Consistory meeting a proposal was approved to raise $\$ 7,500.00$ by August $1976 .{ }^{35}$ In October of that same year, the minutes carry this notation: "Motion carried that Rev. and the elders set up a system of family visitation to discuss spiritual and financial matters." ${ }^{.36}$

The consistory was not just worried about finances and repayment schedules. In September 1973 the consistory asked the Classis to allow them to expand the Consistory by one elder and one deacon. Indicators show that despite financial difficulties, the congregation was continuing to grow. They also sought new ideas and opportunities; the April 1974 minutes include reference to sending a thank you note to Del Vanderhaar in appreciation for a goal-setting session. ${ }^{37}$ Then in May 1975 the Evangelism committee requested more meetings to decide which program to recommend for evangelistic purposes. ${ }^{38}$ The Evangelism Committee's decision was never recorded, and in July 1975 the minutes indicate that the pastor had accepted a call and would be leaving Riverview Park. $^{39}$ From what follows, it seems that the congregation now focused not on evangelism but on the effort to bring in a new pastor.

\section{Pastor \#4}

The congregation and consistory wasted little time in locating its next pastor. Although the history written for the $30^{\text {th }}$ Anniversary indicate that the congregation had previously found its pastors in the Midwest, this time "they went farther a field to call its

\footnotetext{
${ }^{34}$ Minutes of Congregational Meeting, December 1972.

${ }^{35}$ Minutes of Consistory, March 1973.

${ }^{36}$ Ibid., October 8, 1973.

${ }^{37}$ Ibid., April 7, 1974.

${ }^{38}$ Ibid., May 12, 1975.

${ }^{39}$ Ibid., July 14, 1975.
} 
next and current minister... who although a mid-westerner by birth... had been serving a Reformed Church in New York City for sixteen years." ${ }^{, 40}$ In the minutes of the congregational meeting held on December 1,1975 , the consistory recommended calling this pastor and the first vote to extend the call was $28-8$, or a $71.5 \%$ favorable vote, while the second vote was $32-4$ in favor of calling him, or $87.5 \%$ favorable vote. ${ }^{41}$ Those numbers and figures must have been sufficient for pastor \#4 to move his family, for he was installed as the pastor on February 25, 1976.

While the congregation was beginning fresh with a new pastor, the same old problems were still plaguing them, in particular the debt repayment. Once again the minutes of the March 1976 consistory meeting indicate that a new task force was to be organized to "determine where our building fund stands with respect to (a) how much we have paid and (b) how much we still owe. To set a goal and time schedule for another building fund drive." ${ }^{, 42}$

The consistory and new pastor did not just worry about fund raising and debt service exclusively. The minutes from July 1976 indicate the Consistory approved the pastor's training for the Good News People evangelism program. ${ }^{43}$ Good News People had been developed by the Reformed Church In America to train congregational members to do evangelism. Finances were never far from the mind of this body, for later in the year the consistory sought approval from the Classis to borrow an additional $\$ 7,000$ to replace the aging organ. ${ }^{44} \mathrm{~A}$ couple of months later the minutes record a motion

\footnotetext{
40 "Riverview Park Reformed Church 1962-1992, 30 $0^{\text {th }}$ Anniversary".

${ }^{41}$ Minutes of Congregational Meeting, December 1, 1975.

${ }^{42}$ Minutes of Consistory, March 3, 1976.

${ }^{43}$ Ibid., July 5, 1976.

${ }^{44}$ Ibid., October 11, 1976.
} 
to set aside $\$ 75.00$ a month to pay the interest on the building debt. ${ }^{45}$ Nothing is said about paying the principle or the results of the finance task force.

Although the congregation was concerned about building issues, they were also moving in the direction of including more people in ministry. In fact in September 1977, the Consistory approves the participation of lay people in leading the first part of the service. $^{46}$ This practice of a Lay Worship Leader remains a significant part of the life of the congregation even today. This indicates an effort to include the congregation in ministry and service. Additionally, a note from March 1980 indicates an effort at some form of lay pastoral care, for there is reference to a "fellowship pyramid" being formed to take turns to visit shut-ins. ${ }^{47}$ Other than a couple of brief comments in the consistory minutes scattered over the years, there is no other documentation or even memory as to the purpose and structure for these pyramids.

The congregation also sought out new and different means to include more people in the life of the congregation. The minutes of the April 1979 Consistory meeting include a decision "to use a different approach to 'Reach Out" mailers, phones and callers to avoid a lot of wasted time to people who are absolutely not interested in a call or not at home." $" 48$ There is no indication as to who would be trying the different approach, but interviews with members past and present suggest the pastor would have been doing most of the outreach work in this time, as had been the custom of the congregation in the past.

The minutes remain routine until April 1981, when the board of elders met in special session "for the purpose of hearing a grievance from one member of the

\footnotetext{
${ }^{45}$ Ibid., December 13, 1976.

${ }^{46}$ Ibid., September 12, 1977.

${ }^{47}$ Ibid., March 6, 1980.

${ }^{48}$ Ibid., April 9, 1979.
} 
congregation against another and a request for disciplining action against the latter." While no specifics are recorded, the little information available reflects the desire of the complainant to "obtain moral and material restitution." $"$ How this turned out is unknown, and there is no other reference to discipline or other issues relevant to that.

Finances reappeared in the August 1981 minutes, when a delegation from the Classis encouraged the congregation to repay the loan as quickly as possible, because the "interest is causing the Classis problems." recorded. Why the interest was causing Classis problems is confusing, since RPRC's 15year note would not be fully due for another six years. The Classis may have sought an early return on the loan repayment because the congregation was recording increased membership, growing from 86 communicant members in 1975 to 164 members in $1981 .^{52}$ While the membership had nearly doubled, the giving did not seem to keep pace. The same document shows that while membership increased 6\% from 1985-89, giving increased by $7 \%$ during the same time period.

With increasing membership came increasing pressure on the building, so in February 1982 the consistory discussed visitations and the pew fund drive. The minutes include a note on a dreamtime, "asking which comes first, two worship services or a larger sanctuary? All members expressed views and projected growth was made."53 While the congregation could not physically expand the building at this time, the

\footnotetext{
${ }^{49}$ Ibid., April 27, 1981.

${ }^{50}$ Ibid., April 17, 1981.

${ }^{51}$ Ibid., August 8, 1981.

${ }^{52}$ Chart labeled "Active Communicant-RPRC," 1995.

${ }^{53}$ Minutes of Consistory, February 15, 1982.
} 
consistory did purchase some moveable pews in April 1982 that allowed part of the fellowship hall to function as an overflow for the expanding membership. ${ }^{54}$

Little more can be found in the minutes about a dreamtime or even thoughts of expansion, until the Spring of 1983. On February 15, 1983, the "Shaping the Dream Committee" ${ }^{\text {55 }}$ was authorized, a precursor of a building task force. Then, on March 6, $1983,{ }^{56}$ RPRC was given the opportunity to participate in the Adventure in Mission program, known as A.I.M. that placed college students in local churches for a year as missionaries. Deadline for the application to have a college student was the next day, and after an extended discussion the consistory was deadlocked in a tie vote about the decision to participate or not in the AIM program.. The pastor cast the tie-breaking vote in favor of participating in the AIM program, thus, inaugurating the youth position. ${ }^{57}$ The minutes show that the consistory was in favor of this position, but they were reluctant to make this decision without a congregational vote. ${ }^{58}$ While the position may have begun with a little bit of controversy, the congregation recalls their A.I.M. students with satisfaction and appreciation.

The second major development in 1983 includes the move to two services was made at the August consistory meeting. How this decision was reached is difficult to determine from the minutes. The minutes state simply a "worksheet giving information and reasons for the two Sunday morning services was studied and revised by the

\footnotetext{
${ }^{54}$ Ibid., April 19, 1982.

${ }^{55}$ Ibid., February 15, 1983.

${ }^{56}$ Ibid., March 6, 1983.

${ }^{57}$ This is the first "formal" record of the pastor exercising his authority in this way. Based on interviews and other conversations, this pastor was in the habit of expecting decisions to go his way, and things to be done the way he said.

${ }^{58}$ Prior to the Interim pastor in 1995, the Consistory seems to have had difficulty making decisions without being certain of the congregation's approval.
} 
Consistory." 59 The same consistory that did not want to vote on hiring a subsidized college youth worker did not hesitate to modify the Sunday morning worship schedule without congregational input.

The final item of note in 1983 involves the minutes from the congregational meeting of that year. On a positive note, the congregation had a "net gain of 17 people. Rev._ has from 30 to 80 possible new member prospects." ${ }^{.60}$ On the less than positive side a notation states a "questionnaire of how the minister should use his time for the church and congregation was distributed and worked on by those present at the meeting. ${ }^{.61}$ Nothing more is said about the questionnaire, or even the minister's use of his time in any consistory minutes.

1984 appears to have been an uneventful year as there is little to report before the 1984 congregational meeting report giving positive direction with the two worship services:

In the State of the Church Report Rev.__ gave the following statistics on church attendance with two services: the high for the 8:45 service was 140 October 14, the high for the 11:00 service was 103 on November 6 . The low for the 8:45 was 35 on December 25, and the low for the 11:00 was 23 on July 29, and the total high for both services was 206 on February 12. The membership stands roughly at 125 families and 218 members. ${ }^{62}$

This increased attendance is also reflected in the vote totals for Consistory member elections. At that time the vote totals ranged from $85-54$, whereas previous years' recorded votes reflected a much lower attendance.

The other significant event of 1984 was the report of the "Shaping of the Dream Committee." Without going into details, this committee reported on their effort to allow

\footnotetext{
${ }^{59}$ Minutes of Consistory, August 9, 1983.

${ }^{60}$ Minutes of Congregational Meeting, December 1, 1983.

${ }^{61}$ Ibid., December 1, 1983.

${ }^{62}$ Ibid., November 4, 1984.
} 
"each member of the congregation an opportunity to express their own ideas and opinions." ${ }^{.63}$ The report suggests six major areas for consideration and planning: 1) Sunday School space; 2) Fellowship activities and increased space needs; 3) Recreational facilities, which would be included in fellowship needs; 4) Worship space; 5) Debt retirement; 6) Spiritual Commitment and Revival. From the minutes that follow, the consistory appears to have given priority to the first five, while the sixth item appears not to have been addressed at all. An April 16, 1985, memo from the pastor entitled: "Summary of meeting with architect..." architect and what needs to happen in the future. Another memo from the Pastor, dated nearly a year later, is addressed to the "Master Plan Committee," must have been in place. This memo details possible themes for fund raising, a mission statement and some directions from a church-planning book. Ironically, the theme used as a model comes from the Desert Haven Church, which encountered major financial difficulties about this time. (Desert Haven, an RCA congregation in the Southwest, expanding at about this same time. Unfortunately, due to financial irregularities it was closed).

The pastor and consistory approved a Master Plan. The June 1986 Consistory minutes state: "A lot of discussion was held on the Master Plan and how it could be presented in a positive way to the congregation. We need to motivate the congregation on the current debt before we throw a building project on them."

\footnotetext{
${ }^{63}$ Final Report, Shaping the Dream Committee, December 18, 1984.

${ }^{64}$ Memo, April 15, 1985.

${ }^{65}$ Memo, February 26, 1986. The Master Plan was the architect's outline of how the church facility could be expanded and the property utilized in the future.

${ }^{66}$ Minutes of Consistory, June 16, 1986.
} 
said this would be discussed at the Annual Congregational Meeting, nothing in the official record indicates any formal action or activity on this agenda for some time.

The minutes of the 1987 Congregational Meeting hints at some dissension in the congregation: "Rev. talked about the church-how splits occur and are patched up

with love. We discussed happenings in our own church, emphasizing new members and attendance. We prayed and gave thanks for all facets of our church." ${ }^{67}$ While the consistory discussed the budget and allocations, the church stilled owed $\$ 2,000$ on the piano, and the building debt still remained. ${ }^{68}$

The consistory minutes during 1988 are routine, and dissention is again voiced only at the congregational meeting. The November 1988 congregational minutes record:

Rev. _ read a newsletter pertaining to the major cause of a death to an institution that being the loss of a vision. The budget enables us as a church to do something in the community. Time was taken for those in attendance to state just exactly where this money is used and just who benefits from money given to the church for its budget....At the present time $\$ 7,100$ is left on the building to be paid off. ${ }^{69}$

Then, a few sentences later is this cryptic comment: "Time was allowed for anyone to ask questions about the budget and present input. No input was given at this time, giving the impression that everything was alright." ${ }^{70}$ These minutes imply that there was some dissention in the congregation at this time, but it had not yet come to a head. ${ }^{71}$ From the conducted interviews that impression is confirmed. Even though the minutes do not record any opposition, or discontent, the interviews revealed a growing dissention that was looking for a focus.

\footnotetext{
${ }^{67}$ Minutes of Annual Congregational Meeting, December 6, 1987.

${ }^{68}$ Ibid., December 6, 1987.

${ }^{69}$ Ibid., November 20, 1988.

${ }^{70}$ Ibid., November 20, 1988.

${ }^{71}$ One woman interviewed suggested that at this time people were very dissatisfied with the direction of the church, she stated the pastor usually would have a devotion that would stifle any dissention or discussion of issues.
} 
The focus for the discontent becomes evident from the minutes of an "informal" congregational meeting held on Sunday, August 27, (probably 1989 due to its placement but the page is undated). The purpose of this congregational meeting was to discuss the addition design plan and questions around the fund drive. ${ }^{72}$ Questions were asked about the present mortgage, which was slated to be paid off by the end of the year. A question was raised about the outcome of the vote to approve the fund drive and it was reported that the vote had passed with a $65 \%$ majority. Finally, a member asked where the money was supposed to come from. ${ }^{73}$ While there were some comments about loans, the meeting ended with no recorded conclusions or direction. With the insight and vision of hindsight, it is clear there was a building discontent that was either missed or ignored by the leadership of the congregation.

\section{Conflict Erupts}

The minutes from the congregational meeting dated November 12, 1989, appear to be that of a quiet meeting with some question and moderate discussion about the issues related to a building project. The only comments recorded indicate that several people did not like the proposed addition's layout, while others were concerned about cost and how the congregation could pay off the mortgage. ${ }^{74}$ Interviewees said this meeting was anything but quiet and polite. The interviewees talked about heated exchanges between the pastor and those who opposed the building project. They said the meeting began at 7:30 PM, but the pastor left the building at 11:00 PM, declaring he had had enough.

\footnotetext{
${ }^{72}$ Minutes of informal congregation meeting, September 27, 10:00 AM.

${ }^{73}$ Ibid., September 27, 10:00 AM.

${ }^{74}$ Minutes of Annual Congregational Meeting, November 12, 1989.
} 
While there is little information in the minutes of the Consistory immediately following this meeting, or for that matter for another year, one of the interviewees noted that between 60 and 70 people immediately stopped attending RPRC after this meeting. In his words, "They did not just trickle out. They stopped immediately." The minutes of Consistory from November 1990 carry this notation from the Elder's Meeting: "The Elders continue to talk to the malcontents who will talk to them. The Elders will be going through the congregational members list during the December meeting."${ }^{.75}$

The Consistory and Pastor were not focusing on healing or even dealing with the events of the departure of a large percentage of the Congregation, for there is evidence that during the early part of 1990 the Pastor proposed a "Renewal Weekend." Evidently the Renewal Weekend took place as the November 1990 minutes note there was "general agreement that the Renewal Weekend" was a success." ${ }^{, 76}$ That success was not defined. It would appear the success was limited, as a comment occurs shortly thereafter noting that the congregation continues to be behind in offerings.

That financial picture did not improve in 1991, as the February minutes indicate the congregation remained behind on the budget and were now in arrears with the assessment that was due the Classis:

Finances and shortfalls with our monthly budget as well as where we stand with Classis was discussed. A recommendation was made that each family be billed for their share of the Classis assessment. G_, D__ and Rev._ will get together and write a letter to the CP\&D of the Classis to inquire about the possibility of getting our yearly assessment reduced. ${ }^{77}$

The letter that was written indicates a much less dire situation than was indicated by those that were interviewed. The letter states RPRC lost only 22 members between 1989

\footnotetext{
${ }^{75}$ Minutes of Consistory, November 13, 1990.

${ }^{76}$ lbid., November 13, 1990.

${ }^{77}$ Ibid., February 10, 1991.
} 
and 1990. The letter also indicates that the congregation should have gained 6 new members that indicated a net loss of 28 . Even the worship numbers listed only show a net loss of three members a week. Yet the letter indicates the "more financially well off" members left, causing a drop in the offerings. ${ }^{78}$ The balance sheet attached to the letter, dated February 1, 1991, indicated the congregation was running a deficit and could not afford to make the back assessments, much less the current year's assessment.

I could not find any record of the decision by the Classis CP\&D, so it is difficult to know how this request was handled. Another puzzling aspect of this time in the life of $\mathrm{RPRC}$ is the absence of any consultation or involvement by the Classis. This whole event seems to have been dealt with as an internal affair that could easily be handled by the Consistory.

The Consistory did attempt to deal with the continuing financial difficulty on its own. Another undated letter to the Congregation that must have been distributed in 1992, references the $30^{\text {th }}$ Anniversary of the RPRC. This letter is headlined "OUR CHURCH DEFICIT." 79 That letter includes this explanation for RPRC being delinquent in its assessments:

There was a group who were displeased with the direction of the church leadership (Consistory meetings lasted 5 hours or more!). Some of that group (these eventually left RPRC), decided to show that displeasure by failing to contribute to RPRC for any program or mission. This put the Consistory in a bind. Classis assessments are based on the membership as reported late in the year. There were problems with bookkeeping also, and we had been late in 1988 and 1989 in paying our assessments. ${ }^{80}$

This letter was followed by an appeal and a plan to pay off this deficit. Once again there is no record of how this letter was followed up or whether the appeal was successful.

\footnotetext{
${ }_{78}^{78}$ Undated letter to Dakota Classis, Church Planning and Development Committee.

${ }^{79}$ OUR CHURCH DEFICIT, undated letter to congregation 1992.

${ }^{80} \mathrm{lbid}$.
} 
There is also no further mention of Classis assessments either, until November 1992 when it is noted that RPRC owed more than $\$ 1,618.42$ on the 1990 assessment, but they were current on the 1992 assessment. ${ }^{81}$

The time between 1992 and 1994 could be labeled the silent years, ${ }^{82}$ as the Consistory minutes were routine with little or no indication of conflict or resolution. Worship attendance figures, though, indicate a decline at RPRC. The figures submitted to Classis CP\&D in 1991 indicated that in 1990 RPRC was averaging over 170 in two worship services. By 1994 that total dropped to 118 in both services. One man who was serving on the Consistory and considers himself to have been a good friend of the pastor describes this time as "walking on eggshells." Everyone was afraid to try something for fear of offending, and the once-confident pastor was "playing it safe." Another couple that moved to Yankton during this time and worshipped with the congregation for about six to nine months described the situation as one, "where it seemed the leaders had left and only the followers were left behind".

\section{The Final Chapter for Pastor \#4}

The next major incident in the life of the congregation would occur in January 1994, where the Consistory minutes note that Rev. addressed the Elders regarding

his sabbatical. ${ }^{83}$ Most of the meeting minutes are concerned with how to handle issues during the pastor's absence. The minutes never indicated what led to this abrupt decision,

\footnotetext{
${ }^{81}$ Minutes of Consistory, November 1, 1992.

${ }^{82} \mathrm{I}$ use that label as there is almost nothing recorded concerning any initiative to change the status quo.

${ }^{83}$ Minutes of Consistory, January 11, 1994.
} 
and there are no official records concerning the need for this sabbatical. ${ }^{84}$ Correspondence during this time indicated the Elders saw this "sabbatical" as a shortterm solution to a situation they were not sure how to resolve. The Sabbatical would provide a respite in the midst of conflict, but when the pastor decided to return to his duties the Elders sought outside intervention in the form of the Classis Pastoral Relations Committee. Initially neither the pastor nor the Elders informed anyone else as to the nature of the Sabbatical. A memo from the Chairman of the Pastoral Relations Committee contains this paragraph:

Rev.___, at Riverview Park in Yankton is taking a "sabbatical" or temporary leave for a period of 2-4 months, effective immediately. This is a time for rest and renewal, after 18 active years in the parish there and a time for to reflect on his plans for the future, as he approaches retirement. There is no pastoral problem there from what I can gather talking to the elders.... ${ }^{85}$

A letter from the pastor to the congregation demonstrates the pastor intended to

return. The letter, dated February 5, 1994, states:

Thank you for granting me a sabbatical leave. I realize that some of you have assumed more responsibilities... Through this past month we have a new awareness of God's presence. It is amazing to see how God's timing is always right-providing friends and family with encouragement just when we need it most. We are learning to LET GO and LET GOD! ${ }^{86}$

While the pastor may have been expecting to return to the congregation and continue where he left off, the Consistory, which had been described as followers, begin to show signs of leadership. By refusing to allow the pastor to resume his duties, the Consistory demonstrated an understanding that an irreparable breach had occurred. It was this breach that would prevent the pastor from resuming his duties. In February 1994

\footnotetext{
${ }^{84}$ Not only is the Sabbatical among the narratives of harm in this church, but also the reasons surrounding it, which will be partially addressed later.

${ }^{85}$ Memo to Classis Pastoral Relations Committee, January 12, 1994.

${ }^{86}$ Letter from pastor to Congregation dated February 5, 1994.
} 
the Consistory made the first tentative steps in suggesting the two worship services move back to one, but they were still anxious and wanted to poll the congregation before making such a decision. ${ }^{87}$

Even though the Consistory was able to exercise leadership in the realm of worship services, they were unable to move forward in other significant areas. One issue that was hardly even mentioned is the pastor who is on sabbatical. A letter from the pastor to the elders dated March 1, 1994, indicated that he plans to see this sabbatical on the short end of the two months, not the long end of four. In this memo he said he plannned to be back on March 8, stating: "My sabbatical is over." 88 While the pastor has specific time plans and dates in his memo, the minutes of the March consistory are more equivocal about plans as they note: "Specific plans were made and will be announced at a later date." ${ }^{\prime 89}$ It was also at this meeting that the consistory decided, based on the results of the poll of the congregation, to go to a single worship service on Sunday morning at 9:30 AM.

The specific plans that the Elders and pastor agree to are never published and not fully explained. The minutes of the April Elder's meeting contains this paragraph:

It has been understood that Rev.__ is seeking the pastorate of another church. It was motioned, seconded and carried to invite the Pastoral Relations Committee to offer counsel and guidance in formulating policies and plans in this matter. ${ }^{90}$

During the full Consistory meeting these minutes were recorded:

Discussion was held about the upcoming meeting with Pastoral Relations Committee. Also need for congregation to be informed as to what is going on with Rev. has stated that he is interested in seeking a different assignment as pastor. However all agreed that it would be impossible if not

\footnotetext{
${ }^{87}$ Minutes of Consistory, February 15, 1994.

${ }^{88}$ Memo from Pastor to Elders, March 1, 1994.

${ }^{89}$ Minutes of Consistory, March 8, 1994.

${ }^{90}$ Ibid., April 5, 1994.
} 
disruptive to the congregation publish exact details at this time. Rev. Elders $\mathrm{H}$. and G. agreed to draft a letter to the congregation from Rev. and would summarize the sabbatical and explain what the plans will be. ${ }^{91}$ that

Without revealing any confidential information, the Elders informed the congregation that the pastor would be seeking another position. (The elders were so successful in protecting confidentiality that the majority of the congregation today has no awareness of the nature of the events that led up to this pastor's departure.) As the letter indicates, the pastor had updated his profile, but the system takes time to work, and he was uncertain as to what the future would hold. In the time that remained he promised to continue to "give you $100 \%$ of my time, effort and energy."

A memo dated April 7, 1994, from the Chairman of the Pastoral Relations Committee indicates that the committee would meet with the Consistory and the Pastor on April 19, 1994. The memo indicates the problem the Elders and the Pastoral Relations

Committee was hoping to avoid when it notes:

Unfortunately, there is already some division occurring in the congregation over this. Pastor _ feels the Consistory and the Elders in particular, have aligned against him in a power play and some of the Elders feel that the Pastor _ is aligning his personal supporters to defend and protect him from being "ousted" by the Consistory. This has turned into a mess. I was told (by Pastor__ ) that one of the elders no longer attends church and does not speak to him any more. It is clearly time for our committee to step in and hear both sides. ${ }^{93}$

In the course of interviewing various members and past members of the congregation, including several of the elders involved in this situation, there was no mention of anyone leaving the congregation, except one man who had moved out of the community. The

\footnotetext{
${ }^{91}$ Ibid., April 5, 1994.

${ }_{92}$ Pastoral Letter, April 7, 1994.

${ }^{93}$ Memo to Pastoral Relations Committee, April 7, 1994.
} 
general sense of all the elders involved was that of deep and sincere sorrow over what was taking place and the course of action that they felt compelled to follow.

The Consistory Minutes of April 19, 1994, reflect the fact that the appointment with the Pastoral Relations Committee was kept and attended. These minutes state early on: "The purpose of this meeting was to formulate a plan that all parties could agree to as to the timetable and schedule of pay and benefits during the remainder of Rev._ 's service at RPRC." " In the very next paragraph the Elders were asked if "Rev.___ could be effective in another church, and the consistory responded unanimously yes." aspect of the minutes remains a little unclear. The record indicates that by "mutual agreement between Rev.__, the Consistory and Pastoral Relations Committee, that Rev. _ will retire on July 31,1994 , unless he receives a call to service." ${ }^{996}$ It is then noted that Rev. _ was called in to discuss the proposal with the Consistory and Pastoral Relations Committee. The minutes also indicate that there was general agreement by all involved, and both the Pastor and the Clerk signed the minutes. ${ }^{97}$ Then in a letter dated April 21, 1994, Rev.__ complains to the Chairman of the Pastoral Relations Committee that he had no part in the negotiations. He appeared, in his letter, to try to reverse the agreement, suggesting that he would be willing to make his fight to remain as the pastor a matter of public debate if he were unable to receive a call to another congregation. ${ }^{98}$

The deadline never came into play. On June 7, 1994, the request for the dissolution of the Pastoral Relationship between Rev. and the Riverview Park Reformed Church is recorded. Rev. did receive a call to another congregation where

\footnotetext{
${ }_{95}^{94}$ Minutes of Consistory, April 19, 1994.

${ }^{95}$ Ibid., April 19, 1994.

${ }^{96}$ Ibid., April 19, 1994.

${ }^{97}$ Ibid., April 19, 1994.

${ }^{98}$ Correspondence dated April 21, 1994.
} 
he served the next seven years and eventually retired. In interviews, three of the elders from that time unanimously stated there was no personal animosity toward this pastor, only regret. They felt it would have been impossible for him to remain effective in this congregation under the circumstances. After the pastor had left, he frequently returned to the community and maintained contact with each of these men and their families.

\section{Pastor \#4 Leaves}

The Consistory spent the summer months arranging for pulpit supply, which, they proudly announced, did not depend on the Classis to provide. When the Elders could not find a pastor or someone outside the congregation to lead worship, they did it themselves. The Pastoral Relations Committee (PRC) first suggested an interim pastor in September 1994. ${ }^{99}$ In the October 1994 minutes, the PRC's suggested candidate was expected for an interview for this position. ${ }^{100}$ One of the elders during this time stated that two or three people who were asked to consider being an interim pastor. After those men declined to accept the position, several of the Consistory were eager to begin a search for a new pastor. While there was some discouragement over the search for an interim pastor, the Minutes of January 3, 1995, indicate that an Interim Pastor had been found and a contract was being drawn up. ${ }^{101}$ Correspondence from the Interim Pastor indicates he accepted soon after receiving the contract, and would arrive in Yankton in the middle of February 1995, more than a year after the previous Pastor had stepped aside for a sabbatical leave. $^{102}$

\footnotetext{
99 Ibid., September 6, 1994.

${ }^{100}$ Ibid., October 4, 1994.

${ }^{101}$ Ibid., January 3, 1995.

${ }^{102}$ Letter dated January 25, 1995.
} 


\section{Interim Pastor Arrives}

One of the first actions the Interim Pastor (after this Interim) took was to distribute a "Church Attitude Questionnaire"103 and visit as many families as possible before Easter. In terms of program activities, the Interim also offered a series titled "How to Make A New Start." The Interim added this note: "This series is especially designed for someone who has just gone through a major disappointment or loss in their life." 104 While that is what he was doing formally, the Interim once stated to the writer that for the first six months he sat with his feet on his desk, since he had not ever seen a congregation more dominated by its pastor as this one had been. (A side note, the desk he refers to, was a card table, as the former pastor had owned the desk and took it with him).

The Interim's personal observation is confirmed in the report that he made to the Consistory on March 14, 1995, with this paragraph:

Rev. _ outlined the following brief assessment of the needs/wants of RPRC given the knowledge he has gained of RPRC so far:

I. Getting people involved. Present structure makes it difficult to get more people involved.

A. Perception of top-heavy power structure-overcome it by: delegation of authority and communicate it to everyone.

B. Have to look at changing the way we do business.

C. There is generally a lack of knowledge in the congregation as to who does what and who is responsible.

II. Assimilation of People
A. Misconceptions
B. More small group activities
C. More people help w/Sunday a.m. activities increases "ownership."

III. Stewardship: Sizeable potential for increased giving within the attendees and those not attending.

\footnotetext{
${ }^{103}$ A copy of the Questionnaire and results is attached as Appendix \#1. In conversation with the Interim Pastor, I learned that this was a questionnaire of his own devising, not published anywhere else.

${ }^{104}$ Memo to the Congregation, February 27, 1995.
} 
IV. Spiritual Growth Opportunities. Need to be very intentional in helping people get Spiritual growth.

V. Does not appear to be any limitations as to what RPRC can do in terms of goals or where we want our church to go.

A. Church is debt free.

B. RPRC is operating Okay and all options are open. ${ }^{105}$

A more extensive assessment by the Interim Pastor is found in an undated document entitled Observations of Interim Pastor where he states:

The leadership style is top-down individualistic style-From Pastor, Consistory or committee and a recruitment process which "fills slots." There is very little sense of this "is our ministry" in this church. Finally, although the history of conflict in this church can partially be blamed on selfish motives and style of leadership and lack of ownership of the church by many in the congregation, I believe the predominant reason for conflict here was the lack of cohesive vision for the future shared by Pastor, Consistory and Congregation. ${ }^{106}$

Further assessment was offered by the Interim at the April 1995 Consistory meeting where these observations are recorded:

RPRC ministries are generally on an individual level. It is individual efforts not group efforts. Most act independently of each other. Anyone in leadership role at RPRC is pretty much on their own... It was suggested that RPRC needs to have an improved method of communication from Consistory to Congregation. ${ }^{107}$

The minutes also record the first hint that the Interim had more in mind than just assessment: "In essence the type of church the Congregation wants RPRC to be, will determine the best leadership style and what type of person to call as a permanent pastor." 108 In order to determine the kind of "church" the Congregation wanted, "The Visioning Process" was discussed at the May 1995 Consistory meeting. ${ }^{109}$ The process was to be delegated out to committees, but there was concern that the congregation didn't

\footnotetext{
${ }^{105}$ Minutes of Consistory, March 14, 1995.

${ }^{106}$ Observations of Interim Pastor. Document found in files of the church.

${ }_{107}$ Minutes of Consistory, April 30, 1995.

${ }^{108}$ Ibid., April 30, 1995.

${ }^{109}$ There is a significant change in leadership styles and directions here. Under Pastor \#4 the congregation was "sold" on a Master Plan. Now the congregation is encouraged to develop a vision for the future.
} 
understand the importance of their involvement. ${ }^{110}$ While there are no records of what this visioning process looked like, the Interim told the author that he followed the basic outline of three questions: "Where has the church been? What does the church want to become? How are you going to get there?"111

During the Summer of 1995 the Interim Pastor and Consistory worked through a visioning process to determine the future direction of RPRC. The "Elders Recommendations" from the minutes of June 1995 offer this growth goal for worship: "It was agreed that going to two services is not a good option and may not be considered strongly." 12

By September 1995 the Congregation and the Consistory had arrived at a consensus as to the major elements of the Vision Statement. The minutes note that an "overview of the vision statement was conducted."113 The congregation met informally to discuss the Vision Statement, showing that congregational input was sought throughout the development of the Statement. ${ }^{114}$ When a consensus had been reached, a second meeting was set for a formal vote to adopt this statement. ${ }^{115}$ There was a formal Congregational Meeting on September 17, 1995, to vote on the newly developed Vision

\footnotetext{
${ }^{110}$ Minutes of Consistory, May 9, 1995.

${ }^{111}$ By including the congregation in the development of this vision, the Interim Pastor adheres to Kotter's principle of enough people being involved in the change process to make it succeed.

${ }^{112}$ Minutes of Consistory, June 24, 1995.

${ }^{113}$ Ibid., September 10, 1995.

${ }^{114}$ A significant change took place here. The Congregation is involved in every step of the process while in the development of the Master Plan ways were sought to "sell" the plan after it was developed.

${ }^{115}$ Minutes of Consistory, September 10, 1995.
} 
Statement. ${ }^{116}$ While the details of the meeting are recorded, it is significant that the vote was taken by secret ballot and was unanimously approved. ${ }^{117}$

After the Interim helped the congregation develop a Vision Statement, it was time to develop the Profile for RPRC to facilitate the calling of the next pastor ${ }^{118}$. In discussing and developing the RPRC's profile, the consistory decided, "Where the profile conflicted with the Vision Statement, emphasis was given to the Vision Statement to make sure that RPRC moves forward with its 5 year goals."119 Following the development of a Vision Statement and Five Year Plan, the interim pastor remained until at RPRC until November 17, 1996. The reason and timing for leaving is that he was moving to participate in a church planting effort with the Reformed Church In America.

\section{Pastor \#5 Arrives}

The congregation on January 19, 1997, called the current pastor. His first Sunday was April 27, 1997. In a letter to the congregation dated February 5, 1997, he accepted the call and explained the necessity of the delay to assist his children in the move process, and help them acclimate to the move and the new community. (Since he and his family were living less than 80 miles away, it was easy for him to travel back and forth during this time). ${ }^{120}$

\footnotetext{
${ }^{116}$ This document is attached as item \#2 and is still the basis for congregational leadership and direction and as per the original document is affirmed or amended at each annual congregational meeting

${ }^{117}$ Minutes of Congregational Meeting, September 17, 1995. What is significant is that congregation that had so recently been dominated by its pastor could achieve this kind of consensus.

118 The Profile in an internal document used in the RCA to help assist churches and pastors in determining what the congregation desires for a pastor. This includes demographics, as well as salary and financial information.

${ }^{119}$ Minutes of Consistory, November 5, 1995.

${ }^{120}$ Correspondence from Pastor \#5 dated February 5, 1997.
} 
While the congregation was working without an interim or installed pastor, the Elders took measures to make sure visitations continued by dividing the congregation into five "Shepherding" groups, allowing each elder to have direct responsibility for a smaller group of members for hospital visitations or other needs. ${ }^{121}$ The elders also exercised their leadership that spring in celebrating the Lord's Supper, as the minutes indicate: "The Lord's Supper will be held on April 9 and Maundy Thursday, March 27. Elders will preside March 27."122 In a glimpse of what would take place, minutes from the same meeting note that the incoming pastor planned to use Networking, a process to help leaders of the congregation identify their spiritual gifts to assist them in carrying out RPRC's Vision Statement and five year plan. ${ }^{123}$ In that same meeting the Consistory learned Pastor \#5 would pursue a Master's Degree in Marriage and Family Therapy at the North American Baptist Seminary in Sioux Falls. This would be his continuing education for the next couple of years. ${ }^{124}$

After Pastor \#5 arrived in April, the first Consistory meeting time was spent reviewing the Goals of the Vision Statement. The pastor explained the goals seemed too broad to implement. The Consistory decided to focus on families with young children, to delegate facilities renovations to the Building and Grounds committee, and to begin the Networking discovery sessions involving consistory and their spouses. In fact sessions were scheduled to begin on August 27, with small group Bible Study groups beginning

\footnotetext{
${ }^{121}$ Minutes of Elder's Meeting, February 18, 1997.

122 Ibid., March 18, 1997.

${ }^{123}$ Ibid., March 18, 1997.

${ }^{124}$ Minutes of Consistory Meeting, March 18, 1997.
} 
late summer or fall of 1997. With these actions and decisions, the pastor and Consistory began to clarify the vision for the congregation. ${ }^{125}$

The Fall of 1997 also marked the first time the Congregation would do a planned stewardship campaign. ${ }^{126}$ The Consistory approved using The Consecration Sunday program, inviting one of the Synod Heartland Executives to lead the worship on Consecration Sunday. The Fall of 1997 also marked the first time the Congregation reaffirmed their vision statement by voting to continue with the direction that had been established.

Early in 1998, the pastor recommended the Consistory continue to decentralize the decision-making. He suggested that the committees all meet on the same evening once a quarter to facilitate communication between committees, Consistory and between committees. The move was also suggested to encourage more people to be involved on committees, as no one would be able to serve on more than one committee. A second significant event in 1998 occurred in the fall when one young woman spoke to the consistory about her plans to establish a Mothers of Preschoolers (MOPS) program. ${ }^{127}$ She explained that she already had twelve mothers signed up for the first day. The deacons also agreed to scholarship anyone who could not afford the $\$ 5.00$ fee for the program and childcare. ${ }^{128}$ At the same meeting the first reference to the Refocusing process is found. The Pastor requested that two or three candidates attend the Refocus meetings starting in November, continuing through May 1999. This was a pilot project

\footnotetext{
${ }^{125}$ Ibid., May 13, 1997.

${ }^{126}$ Ibid., October 21, 1997.

${ }^{127}$ This marks a significant event in the life of the church for the first time a major ministry initiative has come fiom a member of the church, not the Pastor, and it also reflects the first successful outreach into the community.

${ }^{128}$ Minutes of Consistory, September 15, 1998.
} 
being tried by the Synod to help local churches regain a sense of mission and vision. The pastor also suggested that this was a way for RPRC to give back to the Synod for the help they had received during the interim time.

While the congregation had a vision and direction, the consistory invited Dr. Richard Houts from North American Baptist Seminary to lead the congregation in a goalsetting workshop in February 1999. The workshop would help the congregation continue to move forward with the goals and vision that had been established in 1996. While little came out of the goal setting time with Dr. Houts, the April 1999 Consistory minutes note:

The questionnaire for Strategic Planning should be careful for defining weaknesses and identifying strengths for individuals as well as the church as a unit. An opportunity to identify young people's gifts as well may be useful. Action steps are now needed for the next phase of the Strategic Plan. ${ }^{129}$

This meeting and subsequent planning represented the first step in an ongoing effort to keep the Consistory and Congregation moving in the direction set out by the Mission/Vision Statement. Before taking these revisions to the congregational meeting for a vote, the Consistory held two smaller informal congregational input meetings in the Fall of 1999.

\section{Encouraging Broader Participation}

The Bibles for India program noted in the Consistory minutes of October 1999 show how the Congregation was beginning to take ownership of its mission and ministry. This mission came at the initiative of a young Deacon who had been to a Promise Keepers event. He felt this was a good mission for the Congregation and brought 48 Bibles for the congregation to distribute. With very limited discussion the Consistory

${ }^{129}$ Ibid., April 20, 1999. 
approved this effort and supported this man's initiative, voting to pay the postage needed to send the Bibles to India. At the same meeting, the pastor clarified the purpose of the Refocusing process and how it would differ from what the Interim Pastor had done. The pastor noted that the previous efforts had been focused on conflict, while the Refocusing Process will be looking to the issue of where God is leading the congregation in the future. He also explained that the Refocusing Process would be centered in three Sunday evening meetings that would result in a new or revised Mission Statement. The Pastor also said this process would be much briefer than the previous efforts by the Interim Pastor. $^{130}$

The congregation still lacked a Wednesday night program for anyone under high school age. Consequently in January 2000 the pastor was authorized to discuss a cooperative educational program for children and adults with a neighborhood congregation. Also, at this meeting the Pastor suggested that the Consistory meet every other month and that Ministry teams meet in the month between. This would involve a greater percentage of the congregation in decision-making, and move away from the view of the pastor and consistory "running the church." was eventually abandoned due to the felt need for more leadership on the building proposal begun in 2002)

The months of February and March were dedicated to holding the three Refocusing Summits ${ }^{132}$ asking three major questions, 1) Where have you been? A

\footnotetext{
${ }^{130}$ Ibid., October 19, 1999.

${ }^{131}$ Ibid., March 14, 2000.

${ }^{132}$ Summit is a term used in the Refocusing process to identify the major plarıning meetings. These meetings are designed to be attended by the leadership of a congregation. The themes of these three meetings are identified in the text. More information will be coming in chapter 5 concerning the whole Refocusing process.
} 
"Journey Wall" noted the highlights of the congregation's past. 2) Where are you going? The congregation took another look at its mission and vision and affirmed it with one minor revision. The original spoke of renovating the facility, the version adapted in 2000 states: "We intend to update our church facilities to make them visually appealing and to meet the existing needs of our ministries."133 3) How are we going to get there? With that as the foundation, the third meeting focused on goal setting and determining the top goals for the next three to five years. While the bulk of the evening had involved discussion about building expansion, when the final vote was taken the goals all reflected ministry efforts. When the Pastor asked for an explanation of this shift, the assembled group said they were more interested in ministry first and building second.

After taking the summer to circulate the proposal and seeking feedback, the Consistory asked the Congregation to approve the "Strategic Ministry Plan, 2000" at the Congregational Meeting 2000. ${ }^{134}$ Also at the 2000 congregational meeting it was reported that the youth program had expanded three-fold in three years. The MOPS program has nearly tripled since its inception. When the deacons presented the budget they also proposed that the congregation tithe its income for mission giving. They suggested that $10.5 \%$ of the total giving be earmarked for "local, national and international mission work." ${ }^{" 135}$

The congregation took yet another step toward community involvement in 2001 when the Family Education and Counseling Center (FECC) was formed. ${ }^{136}$ FECC began a year earlier when one of the Deacons attended a Diaconal Conference and said that

\footnotetext{
${ }^{133}$ Strategic Ministry Plan, August 2000, see Appendix \#3.

${ }^{134}$ Minutes of Congregational Meeting, November 5, 2000.

${ }^{135}$ Ibid., November 5, 2000.

${ }^{136}$ FECC is the second major outreach that the church has developed. Once again this initiative came from a member of the church.
} 
since the pastor was pursuing a degree in counseling, RPRC could operate a counseling center. At the same consistory meeting approval was given for the pastor to begin a Doctor of Ministry program that would also enable him to complete his license as a counselor. $^{137}$

It is difficult to know what lead to the growth in the membership, but the Congregational Meeting of 2001 includes a note that one Sunday in September had 150 people in worship, with an average attendance of 110-115 weekly. A chart recording worship attendance averages from 1997 to 2001 indicates an attendance had increase during the first two years of the current pastor's tenure, 118 in 1997 to 129 in 1998, but had trailed off to 103 by 2000 . The average weekly attendance at the end of 2001 was 123. With a growing congregation, the Consistory decided to appoint a "Task Force to study update/replacing facilities." 138

The Task Force soon formulated a plan, and the first step was to place a bulletin board in the front entry to highlight their effort and later to highlight ministry needs in the congregation on successive Sundays. When that effort was completed the congregation had heard from thirteen different ongoing ministry focuses that needed space or improved facilities. ${ }^{139}$ These thirteen ministry focus reports represented just the ministries that were currently being carried out by the congregation. The reports did not include any future plans or possible directions because, due to a lack of physical space, there was currently no room to even consider expanding ministry or programs. Following these presentations, the Task Force sought congregational input by placing response sheets in the bulletins. Unfortunately by October the task force had only had twelve responses to their survey, so

\footnotetext{
${ }^{137}$ Minutes of Elders Meeting, May 3, 2001.

${ }^{138}$ Minutes of Consistory, November 8, 2001.

${ }^{139}$ Ibid., March 21, 2002.
} 
a "congregational summit" meeting was planned to discuss building proposals and ideas. At that same Consistory meeting the pastor was challenged to present his own vision for the congregation. The pastor stated at that time that he had not stated my vision for fear of dominating the congregation and the vision that was emerging. When one of the elders said that they might ignore what he said, the pastor then agreed to present his vision. The "vision" wound up being three different possible directions for the congregation, with the common theme that what was in place in the facility was largely inadequate and needed to be replaced or added on to in some way.

The congregational summit was held on February 2, 2003, and the leadership asked the same three questions that had been used in the Refocusing process. 1) Where have we been? This question focused on developments in the congregation in the past 3 years. 2) Where are we going? This specifically asked where do you sense God is leading this congregation? 3) Finally, how do we get there? The congregation named two or three most important steps to get to the desired goal.

After this meeting the committee was instructed to explore the differences between "New versus expanding versus existing structure." It was also suggested to expand the parking lot immediately, and to explore the options of a multiple purpose/fellowship hall addition for expanded worship. ${ }^{140}$ The Consistory affirmed the direction at its February meeting and encouraged a discussion of existing buildings as well as cost/benefit analysis and rough sketches for a future plan on this site. ${ }^{141}$ At the March meeting, the task force suggested that suitable buildings were either too expensive

\footnotetext{
${ }^{140}$ Report from Special Summit Meeting, February 2, 2003.

${ }^{141}$ Minutes of Consistory, February 13, 2003.
} 
or difficult to access and renovate. A sketch showed the task force's suggested course included a worship center addition directly north of the existing fellowship hall.

The need for a larger worship space is further detailed in the report that notes average attendance between 1997 and 2003. The year 200 included the lowest average of 103 per Sunday, but by 2003 that average stood at 145 per Sunday in a sanctuary that accommodates 160 people at best. This increase in worship attendance represents nearly a 30\% increase in that time span. The report also notes that on five Sundays during 1997 the sanctuary held over 168 people.

At the time of this writing the building task force is meeting with a builder to determine the best design and how to add on to the building. Worship attendance remains high, and the pastor has been given approval to explore the possibility of establishing a second congregation that would be developed as a "congregation within the congregation." This new congregation would meet in the existing facility until such time as it would be strong enough to exist on its own, and then be established as a new congregation in the community with its own facility. The pastor said that if this first congregation, which would focus on people who prefer a more contemporary worship style and a postmodern approach to Christianity. Eventually RPRC should begin a second "congregation within a congregation" that would focus predominantly on the current "20-something" generation that would probably remain in the facility and eventually replace the current congregation. 


\section{Summary}

Multiple themes and insights emerge from this case study and will be more fully developed in succeeding chapters. One major theme that emerged involves the successful interim pastor. Twice in the life of the congregation interim pastors seem to have had a direct impact on the life of the congregation. Another theme includes the impact that youth and their leadership in the congregation. Also, the element of lay ministry that was not honored by the clergy and so had to emerge as almost an underground movement that would eventually lead the congregation forward. Along side lay ministry and contradicting or complicating that dynamic was lay leadership that would not or could not allow leaders to be successful. Still another theme that stands out is the recurring goal setting efforts. It seemed that RPRC was on a regular cycle of plan and study, without ever doing anything with those plans. One of the last themes that emerges is the use of the building. Here is where I find some major ambivalence that seems to be present even today. The final theme is the ability of the congregation to disagree and still remain in community. The above-mentioned are the major themes that emerge from this case and will be given much fuller treatment as the analysis is developed. Keep in mind that these themes are not always straight forward nor easily sorted into convenient categories, for the narratives of harm and lines of hope are often intertwined and woven together developing a tapestry that must be seen in its fullness to appreciate, not only the beauty, but the complexity that is seen.

In the succeeding chapters I will identify both the narratives of harm, those stories and incidents that indicate painful times in the life of RPRC, as well as what I am calling lines of hope, those incidents and events that indicate the congregation can and will have 
a future. While every congregation has its narratives of harm, unless there are lines of hope to build on, no congregation will be able to effectively overcome the narratives of harm without significant intervention and outside assistance.

\section{Alphabetical Listing of Pastors Who Have Served Riverview Park Reformed} Church

Rev. Donald Blom

Rev. Harvey Calsbeek

Rev. David Ellis

Rev. Harold Hiemstra

Rev. Garret VandeWalde

Rev. Rodney Veldhuizen

Rev. Gilbert Visser 


\section{Chapter Two}

\section{History and Processes}

\section{Identifying the Narratives of Harm}

"Experience has taught us that we have only one enduring weapon in our struggle against mental illness: the emotional discovery of the truth about the unique history of our childhood."142 This quote from Alice Miller's book Drama of the Gifted Child addresses individuals and their search for meaning. (Miller's book focuses mainly on child abuse and how to deal with those problems later in life). I believe the search for meaning and understanding applies to congregations and others who would like to understand the forces that shaped them and made them who they are today.

In understanding the history of an organization, the roots of problems, as well as the factors that promote health, begin to emerge. Even more importantly, the theologian and the layperson will begin to see the hand of God that is behind the seemingly disconnected events and situations that have shaped the congregation. While it is important and healthy to seek the hand of God and look for the unique shaping of a congregation, most congregations, like most individuals, would like to keep that past hidden if at all possible. They want to keep the past in the past for fear of dishonoring the past if they look too far back or make changes in current practices. In reality, shame drives that desire to keep things hidden, as my previous research acknowledges. ${ }^{143}$

\footnotetext{
${ }^{142}$ Miller, Alice; The Drama of the Gifted Child, The Search for The True Self, Basic Books, New York, NY; 1997 page 1

${ }^{143}$ Veldhuizen, Rodney; "Shame and Enduring Legacy of Pain"; Unpublished learning Unit in partial fulfillment of Doctor of Ministry Degree at Western Theological Seminary, Holland, Michigan; 2003.
} 
Shame by its very nature thrives on remaining hidden and concealed. Shame has its power in concealment, for once it is brought to the light and is exposed, shame loses its power. Once again due to the very nature of shame and the desire to keep shameful things hidden, shame is rarely uncovered and most individuals and communities go to great lengths to conceal what they identify as shameful. Narratives of harm add yet another layer of harm when perceived as shameful, and hence, remaining hidden from outside scrutiny.

While shame is well known and documented as a personal issue, my contention is that shame also affects organizations such as local churches as well as individuals. Gershan Kaufman in his book: Shame the Power of Caring ${ }^{144}$ provides the basis for understanding shame that applies equally to individuals as well as to organizations:

To feel shame is to feel seen in a painfully diminished sense. The self feels exposed both to itself and to anyone else present... To live with shame is to experience the very essence or heart of the self as wanting.

To live with shame is to feel alienated and defeated, never quite good enough to belong. And secretly we feel to blame. The deficiency lies within ourselves alone. Shame is without parallel a sickness of the soul. ${ }^{146}$

While Kaufman's words give an accurate description of shame, let me try and give a little different picture of what shame is all about. I think we have all had those times when we had done something that left us feeling like we would love to have the ground open up and swallow us, rather than to remain with the people who have just watched us embarrass ourselves. That is an incidence of shame, but the shame that Kaufman is referring to and that I am speaking of is a sense, deep inside that we wish the

\footnotetext{
${ }^{144}$ Kaufman, Gershen, Shame the Power of Caring; Schenkman Books, Inc; Rochester, Vermont. 1985.

${ }^{145}$ Ibid., 8.

${ }^{1+6}$ Ibid., 11 .
} 
floor had swallowed us up long ago, because we know we will never be quite good enough. Even worse than those experiences, shame is often experienced as we have let ourselves down.

Donald Capps in his book The Depleted Self, Sin in a Narcissistic Age ${ }^{147}$ uses an analogy I am familiar with. He describes a preacher who has delivered a sermon that the congregation considers good, and yet in the quiet of his of fice, the preacher begins to feel a deep sense of shame because it was not as good as it could have been. ${ }^{148}$ Where did the shame come from? It was the internal sense that he will never be good enough and will never measure up. As Kaufman notes, shame is a sickness of the soul.

Where as I noted, Kaufman's comments refer specifically to an individual sense of shame, yet the members of local churches and congregations I have encountered have expressed those same statements when referring to their congregation. Shame is the feeling that the particular local church does not quite measure up to a "standard" that remains undefined. Most often this attitude is seen in an area where a congregation would normally be seen as a vibrant, thriving congregation except when compared with much larger and more "successful" congregations. The same lessons are relevant when applying Miller's comments to local churches: "people are driven by unconscious memories and repressed feelings and needs that determine everything they do or fail to do." ${ }^{\prime 49}$ Shame prevents a congregation from realizing the unique shaping God has provided. Shame holds them back from that unique mission God has called them to.

Shame also limits a person's and a congregation's range of choices, or as Capps notes:

\footnotetext{
${ }^{147}$ Capps, Donald; The Depleted Self, Sin in a Narcissistic Age; Fortress Press, Minneapolis, MN. 1993. ${ }^{148}$ lbid; p.76.

${ }^{1+9}$ Miller, p. 2.
} 
...the frequently self-constricting nature of shame experiences. They cause one to become less spontaneous, less free-spirited, more cautious, more calculating and less favorably disposed to the element of surprise."

That might begin to explain why so many congregations today are unable to freely choose to change anything in the life of the congregation. If shame, the sense of being significantly diminished, also restricts a person's, or congregation's range of choices, and makes them cautious and less open to being surprised, it should not be a surprise that congregations are invested in remaining the same year after year.

Before a congregation can face that shame, they have to come to grips with their history and past. Theologically this is identified with confession, and according to shame theory, confession uncovers the shame that strives to remain concealed. Whatever title or description is given to this process, there is power in identifying and owning the story and history of life together. Healing also takes place when a person or community finds its story being told once again.

While that provides a background into the psychodynamics of shame, the second component that needs to be exposed include the narratives of harm that comprise the "unconscious and repressed feelings." While Cozad-Neuger calls this behavior a "narrative of harm," theologians and pastors have a much older term for that, simply, sin. For any behavior that harms another can be called nothing else. Once again, while the primary reference to narratives of harm relates to intimate relationships, I have argued in an earlier paper that this framework could be broadened to apply to many different situations and circumstances. ${ }^{151}$

\footnotetext{
${ }^{150}$ Capps, Donald; Ibid. p. 79.

${ }^{151}$ Veldhuizen, Rodney "No Time to Be Neutral"; Unpublished learning Unit in partial fulfillment of Doctor of Ministry Degree at Western Theological Seminary.
} 
While the congregation needs to be empowered to deal with the narratives of harm that are found in the lives of the members of the congregation, these same congregations need to be empowered to face the narratives of harm that affect their life and thinking before they can empower others. Narratives of harm in an institution often reflect a founding story, or early narrative of conflict in the life of the institution. That narrative affects the life of that institution until a new narrative, a narrative of healing, is written.

One of the problems in many institutions is that the founding narrative of harm is also shameful and, therefore, is rarely if ever discussed or examined. If the founding narratives are shrouded in shame, then the researcher or pastor might need to ask the same question in a different way. For instance, it could be asked, "What is the DNA of the congregation/ institution? Why was it begun? What was the founding vision?" Questions like these will enable the observer to better understand what is currently taking place in the life of the institution. These questions will also likely uncover some of that founding shame and pain that have remained hidden but active in the life of the community.

In examining the history and uncovering the narratives of harm, a picture of the forces at work in the life of the congregation begins to become clear. Merely understanding that history and identifying those narratives is a healthy process, and for many congregations would be enough to bring about the start of health.

I find that this case study also reveals how the narratives of harm begin to form an ongoing story and can be traced through the life of the local church. This chapter will trace those narratives of harm and demonstrate how they coalesce into the eventual 
removal of Pastor \#4. Following the leaving of Pastor \#4 these narratives continue to impact and affect the life and ministry of the congregation that lived through that difficult period.

While there are multiple narratives of harm that have afflicted Riverview Park, the one underlying theme that is not easily identified is that of shame. While it is difficult to see from the outside, the congregation for most of its life has been treated as the child who could never quite succeed. From the "failure" of the founding pastor to the eventual departure of Pastor \#4, the congregation appears as if they never quite resolved the basic questions of belonging. Since they were "rejected" by their parents (The Classis and Synod), they in turn have been steadily rejecting their parents (pastors) ever since. This is one narrative that was not resolved until the Second Interim Pastor arrived.

Helping congregations resolve these narratives of harm and issues of shame is not always straightforward or simple. An analogy from individual counseling might help explain this complexity.

If an individual begins to notice the effects of shame and seeks out a therapist, most therapists will seek to treat shame as depression or some other mental illness. This is not due to the inadequacy of the therapist, but the nature of shame. In local churches, those who seek to be the therapists for the congregation suffering from shame also misdiagnose the dynamics of shame that are present, missing entirely the symptoms and their source. So, instead of taking the time to uncover the congregation's past and to look into the forces that have shaped the community that is seen today, the "therapist" prescribes the latest program and suggests the leadership see him again if the symptoms persist. Given that the source of the problem is never addressed, the programs fail to 
achieve the desired results, making the "shamed" congregation feel like a failure once again. Similarly, the individual treated for depression fails to recover and is shamed once again, reinforcing his/her sense of failure. Likewise, the local church therapist blames the patient for not recovering after his incredibly insightful diagnosis and treatment plan. The end result for the individual or congregation is only more pain, never health.

What becomes apparent under examination is that Riverview Park Reformed Church received many such prescriptions over the years. There are references to selfstudies, goal-setting sessions, and outside consultants brought in to help the struggling congregation. In fact Lay Witness Missions and Renewal Weekends designed to help "revitalize" the congregation, never achieved the desired goals. It was not until the Interim Pastor stopped the congregation long enough to take a look back at the story of their corporate history that they began to move toward health. This was after more than thirty years of misdiagnosis and increasing shame of being a congregation that had not lived up to its potential.

Like an individual, one of the problems in many institutions is that the founding story of the congregation often contains a narrative of harm. Many congregations were established due to another congregation splitting, or a family conflict. Still others are founded as immigrant communities, and when the immigrant population is no longer present or another immigrant population replaces the original, the search for a new purpose is often difficult, if not impossible to develop. Contrast that with a congregation that I served in southern Iowa. The congregation was a union of the First Reformed Church and Congregational Church. The Reformed Church was established to serve the Dutch community that was migrating from Pella in the early 1900s. The Congregational 
Church, on the other hand, was established in 1832 (two years before Iowa achieved statehood) by a pastor from Andover Seminary, while the community was still very much on the frontier. The founding pastor was a member of the "Iowa Band," a group of graduates from Andover Seminary, who were seeking to "evangelize Iowa." This congregation was one of several these men founded in the eastern part of the state. Unfortunately, $150+$ years later, the vision had diminished from evangelizing a state to staying alive in a dying community. It is clear that a congregation that was established to evangelize a state or a region carries a much stronger call to health than a congregation established because a core group was unhappy with the previous congregation. (It is easier to build a Christian community on hope than it ever is on hate.) Unfortunately for this congregation, which once boasted the largest building in the town, the vision and drive of the founding pastor had been lost. The only drive that was present any longer was a desire to survive. That founding vision of optimism and purpose had been replaced by a struggle to keep the doors open.

The origins of the Riverview Park Reformed Church came from the Regional Synod of the West and the Classis of Dakota. These two groups decided that Yankton, South Dakota was a good place to begin a new Reformed Church. (With that kind of beginning, the founding narrative should have been that of the pioneer spirit on the plains reaching to an underserved area.) As a matter of record, when the building was erected there was nothing but cornfields to the east, and the building itself was on the very end of $19^{\text {th }}$ Street. Immediately north and west of the structure was a new high school, and a new housing development was planned just to the east of the property. What should have been a stirring founding narrative instead became a narrative of harm. Rather than 
sending a pastor to recruit a group of people who would develop a nucleus to build a congregation that would build the facility, the building was built and the congregation was invited to come. The concept seems to be that of the movie Field of Dreams, if you build it they will come. ${ }^{152}$ Unfortunately, that would not prove to be the point, and the congregation would struggle for most of its existence.

Underlying this founding story is an even more dangerous theme, dangerous because it is largely unseen and unrecognized and that is the theme of hierarchical leadership. The congregation was founded by the decision of men who would never live in the community and built by people who would never worship there. The founding of this congregation involves no local involvement, only the intervention of others who sought to extend the reach of a denomination that was growing at the time. While that sounds like a worthy goal and a good reason to begin a new congregation, it functions as a narrative of harm because people outside the congregation made all the decisions. The decision to plant the local church was handed down, not driven by the people involved in the congregation's beginnings.

\section{Conflict Management}

The second situation that has influenced the life of the congregation is found in the area of conflict management. The Minutes of Consistory record an unusual meeting that was held for the purpose of disciplining a Sunday school teacher. ${ }^{153}$ According to that record, the teacher was relieved of her duties due to an unchristian attitude and

\footnotetext{
${ }^{152}$ Robinson, Phil Alden; Field of Dreams; Universal Studios; 1989.

${ }^{153}$ Minutes of Consistory, November 24, 1962.
} 
relations with other members of RPRC. The removal of the Sunday school teacher is in and of itself a minor detail in the life of a congregation. The problem is magnified in this congregation with its occurrence so early in the life of the church. While it is difficult to know exactly what took place with this woman, the way the conflict is described sounds from this distance to be a quarrel between members that got out of hand and was taken much too seriously at this stage in the life of the congregation. If this had been the last time conflict or complaints were mentioned or these actions were found in the life of RPRC, this would be left as an historical note. Instead what emerges is a congregation that deals with complaints and gossip for much of its life. The minutes deal with complaints repeatedly, and most pointedly, in December $1968 .^{154}$ At that time the Consistory voted to put a note in the bulletin informing the congregation to stop complaining about their actions unless a person wanted to deal with the consistory face to face. This narrative of harm could be identified in this way: "The most anxious person sets the course for the life of the congregation." (Based on Systems Theory, the most nervous person tends to control most situations unless someone else challenges them.) Unfortunately, that did not seem to stop the complaining, nor would it deal with the narrative of harm. The congregation had always had a cadre of people who criticized every pastor who served RPRC. Also, as a corollary to this narrative of harm is the assumption that those who disagree with the gatekeepers of the congregation are to be expelled, which would fit in with the succeeding narrative of harm.

The congregation was not alone in the development of narratives of harm. The Classis and the Regional Synod established a third narrative of harm when the founding pastor proved unable to meet the expectation of growing a congregation. When the

\footnotetext{
${ }^{154}$ Ibid., December 12, 1968.
} 
Classis finally stepped in to remove the pastor, he was charged with "being uncertain as a pastor in the area of purpose and goal." Upon examining the vision that the leaders developed it is clear that the only purpose they could articulate for the congregation was the desire to have a "local" church! $!^{155}$ There is no clear goal as to membership numbers, who the prospective members might be, or even why they existed. That is not all the fault of the leadership; they were placed in a "building" before they had a chance to lay a foundation for the congregation. The only purpose found in the vision statement involves the issues of providing Christian fellowship. ${ }^{156}$

Leaving the question of purpose and direction aside, the narrative of harm that is written by the decision of Classis in the removing of the founding pastor is the narrative that the clergy are responsible for the health and vitality of the congregation. It seems that no one took a look at who was a part of RPRC. There was no self-study undertaken to see who was joining the church, or any questions about why the congregation was not growing. From this distance it would seem to those overseeing this congregation that the answer was "self-evident" -- a new pastor was needed.

There is some merit to the reality that the pastor is called to lead the congregation, and, therefore in turn shares that responsibility of helping a congregation grow and reach its potential. Unfortunately, the actions of the Classis set the congregation up to expect the pastor to follow the lead of the congregation or have the courtesy to leave at their behest and complaint. The next two men would do just that. Both Pastor \#2 and Pastor \#3 left RPRC after only five years. A relatively short tenure for a pastor serving a

\footnotetext{
${ }^{155}$ Chapter 2, page 2.

${ }^{156}$ Minutes of Consistory, November 20, 1962.
} 
congregation with the growth potential that was expected from this community, unless the narratives of harm are taken into account.

Pastor \#4 in many ways is responsible for ending the function of this narrative in the life of the congregation today. While both Pastor \#2 and Pastor \#3 left RPRC after only five years Pastor \#4 would remain a total of eighteen years, and by the time the congregation split he had been the pastor longer than the previous three pastors combined. In simple terms this pastor outlasted his critics, and without understanding the dynamics at play, refused to follow the rules of the narrative, and hence, robbed it of its power. What he also did not understand, nor could he have been expected to understand, was that acting contrary to the reigning narrative carries with it a cost. In this case, it cost him a substantial amount of personal capital, and robbed RPRC of needed momentum at a time when it seemed they would finally escape the "small church" mindset. The tenacity, some would say stubbornness, of Pastor \#4 challenged the members who believed the pastor responsible for the problems of the church, eventually these individuals left the congregation. Unfortunately, these people had kept the leadership of the congregation within a tight circle. When they pulled out, the congregation was left with the followers who had not been allowed to lead and were additionally shocked by the departure of such a large group all at once from their midst. The narrative of harm that made the pastor solely responsible for the life of the congregation once again would not be addressed until later in the life of RPRC. 


\section{Money and Stewardship}

The fourth narrative of harm that can be identified as active in the life of RPRC relates to the issue of money and stewardship. For this congregation money always seemed to be in short supply, leading to the popular myth, "We are a poor congregation and cannot afford to do pay for things on our own". This appears early in the history of the congregation. When Classis inquired into the health and growth of the congregation, the Consistory responded that people were afraid they would be obligated to pay for "this expensive property." 157 The second instance is observed in the minutes when a contract is signed with a nursery school to contract with them to provide an extra $\$ 100$ a month income.

Evidently, finances did not improve a great deal when the second pastor arrived, because he asked about the possibility of serving as the pastor of a congregation in Nebraska. (While that crosses state lines, it is geographically only about twenty miles away) At this time it is hard to discern the reasons for turning this option down, but the congregation was not willing to approve this arrangement. When this arrangement was denied, the congregation then turned to the Classis to ask for "additional support as the cost of maintaining a resident pastor increased." ${ }^{\text {"158 }}$ While multiple incidents could be cited, the final citation for financial purposes comes in 1971 when the Classis asked RPRC to assume the debt on the building and the consistory suggested holding off the repayment and debt assumption until $1974 !^{159}$ As it would work out, the congregation was unable to pay off the debt until late 1989.

\footnotetext{
${ }^{157}$ Ibid., October 24, 1963.

${ }^{158}$ Ibid., December 12, 1967.

${ }^{159}$ Ibid., August 2, 1971.
} 


\section{RPRC Splits}

All these narratives of harm finally merged into a mega narrative late in 1989. As the case documents, the leadership began to study the congregation and the building with an eye to expanding the facility in 1983. This decision making process would extend over the next six years until the Fall of 1989 when three narratives [the narratives that 1) conflict is a part of RPRC, 2) we are a poor congregation and 3) the pastor is responsible for what happens] joined forces to oppose what was perceived to be the pastor's plan to build a gymnasium. What developed from that situation has itself now become a narrative of harm. The congregation today is not able to freely choose among the possible options even now that they are once again moving toward health.

The popular accounting of the split, or exodus, is that the pastor pushed a building project, which was way too much for the existing congregation to even begin to think about. Helping to accelerate this division was the decision to move to two services. The minutes recorded from that time show little congregational input into this decision. Therefore, building projects and two worship services are not options that are considered lightly. Even at this writing, as the congregation wrestles with the concept of a building once again, the suggestion of going to two Sunday morning worship times is hardly given any consideration at all. The pastor has been allowed and encouraged to pursue a second congregation that would meet in the facility and help fund the building, but not a second service of the same congregation.

While the congregation tells the story of a failed building project, further research and investigation reveals a much different story about this project. Looking back at the consistory minutes, there were many opportunities given for congregational involvement 
in the process, beginning with the "Shaping The Dream Committee." This move was not done quietly, and they seem to have sought out congregational involvement and opinions along the way. This desire to allow and invite congregational input is documented in the report from the committee in the minutes of December $1984 .{ }^{160}$ This committee is later followed in 1985 by a "Master Plan Committee" of which there is little more said. What needs to be considered is that the Consistory and various committees were working collaboratively, with some reporting going back to the congregation. What is also significant is that the minutes from congregational meetings held in both 1987 and 1988 indicate there was some dissension and hints of congregational unrest, but it was either ignored or glossed over in the desire to move forward with the building proposal. This historical record is backed up with interview data, both formal and informal, that indicates many people were involved at every stage of this process. While Pastor \#4 may have been a driving force, he was not alone in pursuing this project. The conclusion passed down in the popular story, is that RPRC split over a building project. The popular account also states that this split was facilitated as the result of the two worship services. To keep this popular story alive, the congregation or researcher has to ignore the deeper issues that are revealed by the narrative of harm.

This congregation had sanctioned conflict as normative and complaining about the pastors was a cue for them to leave. According to one woman, who has been identified as one of the primary instigators of the split, Pastor \#4 just would not leave. That interview had been conducted prior to researching the consistory minutes and the researcher considered her words to be that of the person who had been on the losing end of the power struggle. Upon examining the consistory minutes, it became clear that the

\footnotetext{
${ }^{160}$ Final Report, Shaping the Dream Committee, December 18, 1984.
} 
division that occurred in 1989 was centered on the building project. While this became the rallying point for many, the building itself had little or nothing to do with source of the conflict. In counseling terms, the congregation squabbled over a symptom of their problems without ever addressing the real issue, which was the tenure of Pastor \#4. To confirm that hypothesis I have questioned several members of RPRC who were not directly involved in leadership at the time without disclosing my conclusion first. What I found in these informal interviews was a consensus that at the heart of the conflict was not a building, but a disagreement over Pastor \#4's tenure. One elder even suggested that the issue was even more personal for one woman because she felt the pastor did not act strongly or quickly enough to prevent her daughter's husband from getting a divorce. From this woman's perspective it was Pastor \#4's fault that the marriage failed!

While the conflict may have been "personal" for one woman, others interviewed complained that Pastor \#4 manipulated membership figures. One man told of traveling to a Classis meeting and being asked by Pastor \#4 to sign off on the Consistorial report reporting more members than this man could account for. When Pastor \#4 was asked about the figures, the response was the elder should just sign the paper and not ask questions. While another elder could refer to the congregation as stingy in regard to its money, inflating, or exaggerating membership figures would have had two effects on the life of the congregation struggling to provide sufficient income to meet expenses. The problems that develop with inflated membership figures is that the larger the reported membership, (at one time RPRC reported a membership of nearly 400) the larger the assessment, and also the larger the pastor's salary. Others who were interviewed who had either left RPRC and returned or had never returned told of Pastor \#4 transferring 
money in various accounts of the congregation without consultation or knowledge of the deacons. There were also other real or perceived financial irregularities attributed to Pastor \#4. Additionally, and this was told to the researcher in an off-handed manner, Pastor \#4 tended to use the Nominating Committee to try to elect people who were favorable to his own position. The final evidence that the building proposal was only the presenting problem can be seen from the records of the Interim Pastor. The Interim Pastor stated that the congregation asked for more involvement in the decision making process as they previously perceived everything was run by the pastor and the secretary of RPRC.

The final years of Pastor \#4, while relatively devoid of any conflict, are equally devoid of any major innovations. As has been noted in the case study, the pastor and the leadership at this point are afraid of offending anyone and therefore no activity is attempted, either positively or negatively. For the majority of the congregation, Pastor \#4's sudden and unexpected departure must have created some consternation. Officially and realistically, the reasons behind the Pastor's sabbatical and eventual departure are not public knowledge. Occasionally some rumors surface, and this too can be seen as a narrative of harm. Hopefully this is the last narrative of harm to befall this congregation and its ministry.

\section{Miscellaneous Narratives of Harm}

The above are the "historically" developed narratives of harm, although other themes resurface from time to time. One is the reliance on goal setting and planning. It is noted several times in the history of RPRC that a self-study was conducted, or a goalsetting meeting was held. Normally, those efforts would be identified as positive 
developments in the life and ministry of the congregation. I have identified these as narratives of harm, as little change seems to follow these events. The self-studies and the work of goal setting were exercises in management that resulted in little or no change. It seems that most of these efforts were directed by someone from the outside, either from the Classis or the Synod level, and were largely ignored by the congregation it was intended to assist.

Unfortunately, a lot of effort that rarely changes anything is the history of many if not most of the goal setting efforts I have been involved in over the years with several different congregations. A great set of ideas is developed, written down, and promptly forgotten by the group as a whole. It was not until the Interim Pastor invited the congregation to take ownership of the congregation that the members began to take ownership of the goals and dreams they had developed. In fact, the interim significantly increased the congregation's level of involvement, which made a dramatic difference in contrast to the failed efforts at goal setting. Prior to the Interim Pastor's efforts, these plans had depended on someone from the outside to drive the efforts, thus the congregation felt little ownership for the goals and dreams.

Prior to the Refocusing effort that lead to success in goal setting, I tried to use those same techniques in bringing in a "consultant," Dr. Richard Houts to assist in goal setting. That effort yielded the same results the congregation had seen before. Fortunately, that was not the end of the effort at looking ahead and listening to the needs of the congregation.

For the congregation of Riverview Park Reformed Church, these narratives of harm have begun to exercise less and less power. That loss of power has come from the 
naming and owning of the losses involved. During the first Refocus Summit, the congregational leaders assembled a history of the congregation called a "Journey Wall." In reviewing and talking about that history, the leadership experienced one of the most powerful moments in the process when the assembled leadership looked over the history, with the good and the bad, of the congregation, noting that God has been trying to build a congregation here for 35 years. That simple observation seemed to sum up 35 years of pain and frustration, as well as providing hope that their efforts had not been in vain. That is a powerful understanding of the narratives of harm. Just because the narratives are part of the history, does not mean they have to remain predictors of future problems. With these narratives out in the open, they have already lost a lot of the power they once held. As I interact with the leadership about the future, we have been able to identify these narratives of harm and we have begun to understand what is different today from twenty years ago.

Yet, if I were to say the narratives of harm have all been written, I would only fool myself. Riverview Park Reformed Church is still part of the Church militant, and until it is taken off the earth by the return of our Lord, or the eventual decline of the congregation, there will be more narratives of harm that will need to be exposed and understood by yet another pastor or researcher.

The major danger facing any congregation is to believe that once these ideas and issues have been surfaced, the work is complete. The reality is that identifying and labeling the narratives of harm is an ongoing process. Just as the process adopted by the Interim Pastor needed to be repeated by the congregation and myself, there is an ongoing need to keep utilizing that process to ascertain where God is leading the local 
congregation. This process helped the congregation continue the momentum they gained with the Interim, so there is a need to revisit this process on a regular basis to enable newer members of the congregation to understand the vision and direction of the congregation and to contribute their part to that vision as well.

\section{Remaining Narratives of Harm}

Gradually, these narratives of harm are loosing their power to hold back the congregation. While many of these narratives have been robbed of their power, the question of building still remains. Even as I am working on this project, a Building Taskforce is raising funds for an addition to the existing structure. The congregation approached this slowly and methodically, knowing that the past was looming right behind them. What seems to be happening is that the harm of the building project past is slowly fading into the distance and the congregation is now ready to look ahead.

While many of the narratives have been told, the one narrative that has never been addressed was the basis for Pastor \#4's departure. At this point there are only a handful of people within the congregation who know the whole story. The reason it remains hidden is not the cost to the whole congregation, or even to Pastor \#4 (he is deceased). There is a family who remains active in the congregation who would be devastated if this were to be made public information. For that reason I will probably never be able to surface this narrative as long as I remain the pastor here. As I have learned as a therapist, there are times when wounds cannot be addressed. As openness and dealing with issues is becoming part of the life and health of this congregation, it is my desire that twenty years from now, the reasons behind Pastor \#4's departure will be seen as a footnote in the 
life of a healthy and vibrant congregation that is no longer plagued by the narratives of harm. 


\section{Chapter Three}

\section{History and Processes}

\section{Identifying the Lines of hope}

While the list of narratives of harm is long and deadly, alongside these narratives of harm lives what I am calling "lines of hope"! I define lines of hope as those stories or situations that congregations/individuals are happy to tell anyone about. These are the stories when a person or a local church found success in life. While not documented by any research, no congregation can persevere if nothing positive is taking place in the life of the community. Most of those lines of hope I refer to are not discovered in the Consistory minutes. Although there are some, most of these surfaced in the 2000 Refocusing process and are documented in the "Strategic Ministry Plan, August 2000."161 In developing that plan, the congregation dedicated an evening to looking back at the history of the congregation. They developed a timeline history, examining the good times and the difficult times in the life of the congregation. One significant finding from this time line was the long history of music and choirs in the life of the congregation. Not only has the congregation emphasized and utilized an Adult Choir, which at one time numbered nearly 35 members, but there has also been a tradition of children's choirs. The current arrangement includes a Cherub Choir, for children three years of age through Kindergarten, and a Children's Choir for children in First Grade through Fourth Grade. Additionally, RPRC had a tradition of large Christmas musicals, beginning in the early 1970's. Paralleling the choir emphasis is the large number of the

\footnotetext{
${ }^{161}$ Riverview Park Reformed Church, Strategic Ministry Plan, August 2000. (See Appendix \#3)
} 
membership who play what are normally known as band instruments, as well as both piano and organ. Currently, the assistant High School Band director is a member of the congregation, and on a monthly basis writes instrumental music. He encourages the members of the congregation who play band instruments to form a "Praise Band." In fact, this "praise band" is the most recent evidence of this line of hope in the congregation. The story of musical involvement by the congregation is one of the longest lines of hope that can be traced through the life of the congregation.

This line of hope also runs counter to a major narrative of harm, that of a topdown leadership. One complaint that surfaced was the Pastor and the secretary had run RPRC. From what I have found, none of the pastors had more than a limited involvement in the music life of the congregation. In RPRC the music ministry has remained the exclusive domain of the laity. The line of hope displayed in the development and participation in choirs and music is a result of the leadership of the lay members of the congregation. While the congregation has had pastors who enjoyed music, none of them led or directed the choirs. Members of the congregation, who enjoyed music, have developed the choirs and musical groups and have encouraged the youth and teens to develop leadership roles in the life of the congregation.

\section{Youth And RPRC}

Thus, a second line of hope includes youth and their involvement in the life of the congregation. While RPRC has sponsored or worked on developing programs such as Boy Scouts and Girl Scouts, there also seems to have been an active Senior High Youth program, or Reformed Church Youth Fellowship (RCYF). Not only did this program 
allow the Youth a place to develop leadership and a place to meet with friends and nurture their faith walk, it also allowed the teens a modicum of freedom of expression as is seen in the development of The Place. ${ }^{162}$

While there are no longer any members of this Youth Group involved in the congregation, The Place was a room in the building with an outside entrance that allowed the teens a place to come together in the 1970's in a "Coffee House" setting. In an informal interview, an elderly woman in the congregation told me her husband used to be the "sponsor" of The Place he would stay at the church building when it was open, and when something was broken by the teens, he would make certain it was repaired before anyone else knew about it. This gentleman was also a favorite among the teens when it came time for the annual "Soup Supper" or Soup Kitchen, as they are known here. On the President's Day holiday that always preceded the event, this man spent a day teaching the teens how to make homemade noodles for the chicken noodle soup. Members who had been teens during this approximately twenty-year period remember working with him as the highlight of those days. It seems making noodles was a sideline to being with this gentleman.

Once again, that tradition of focus on youth remains alive and well in the life of the congregation. Also running through this story of Youth leadership are men and women who volunteered their time to help ensure this program continued. Given that teens need models to develop their faith, the adult mentors surely play a large role in the development of this line of hope in the congregation's history. While there is no full time Youth Worker at the current time, the Youth ministry continues with support and involvement from the pastor and a cadre of volunteers.

\footnotetext{
${ }^{162}$ Minutes of Consistory, October 11, 1971.
} 


\section{Renewal and Revitalization}

A third line of hope that surfaces through the life of the congregation is the line of revitalization. The first effort at revitalization appears to be a self-study that evidently involved members from another congregation. While the minutes are not clear as to the findings or the results, the effort indicates a desire to improve the life and ministry of the congregation. ${ }^{163}$ On the other hand, since the minutes also include a note about needing more time to work through the report due to the many problems in RPRC, ${ }^{164}$ it is probable that someone from the Classis or even the Regional Synod had suggested this course and the congregation did not engage the process well. A second effort is referenced in minutes from 1974 that record a goal setting session held by a Regional executive who focused on evangelism and outreach. ${ }^{165}$

A third effort at revitalization appears in the minutes of February 1971 where a Lay Witness Mission is noted. ${ }^{166}$ The Lay Witness Missions were a short lived effort during the early to mid 1970 's to revitalize congregations using teams of lay people to share their experience with Christ in a local church setting over a weekend. While highly popular during this time, the efforts seem to have had little lasting effect on the congregations that participated, and Yankton is one where little seems to have changed. While there appears to be little lasting change, this involvement reflects a desire by the congregation to try new methods and means to grow the congregation. At least for a short

\footnotetext{
${ }^{163}$ Ibid., October 12, 1968.

${ }^{164}$ Ibid., October 12, 1968.

${ }^{165}$ Ibid., April 7, 1974.

${ }^{166}$ Ibid., February 8, 1971.
} 
time, there were small groups meeting for Bible Study and prayer as a result of the Lay Witness experience.

The Consistory also considered an invitation to participate in the Faith and Action program sponsored by the Institute of Church Renewal. ${ }^{167}$ Once again that is the only reference that is found concerning this program. Given that the Lay Witness program and the Faith and Action were both developed by the same organization, it would seem that this was another attempt at renewal or revitalization.

While all these lines of hope can be traced through the history of the congregation, the narratives of harm that are never addressed always overshadow and eventually overpower the lines of hope. That changed in 1995 when the Interim Pastor invited the congregation to step off the treadmill of trying to do more and more and helped them take a long hard look at where they had been as a first step. They discovered that the small group of people that had controlled the congregation in the past were now gone. While Pastor \#4 had his problems with leadership, his enduring legacy for the congregation was to outlast the group who had traditionally held back the congregation from growth. Either by sheer tenacity or force of will, or some would say his competitive nature, he refused to give into hints and intimidation that he should leave. As a result the congregation eventually split, but the group that remained had an opportunity to become healthy if they chose. The first crucial step was to examine the past. One of the first observations the Interim Pastor noted was how Pastor \#4 had so totally dominated the congregation. While that is not a positive direction for a local church, that domination also allowed the controlling group a place to focus their anger. Eventually they decided

${ }^{167}$ Ibid., August 2, 1971. 
they would leave since the pastor would not. This ended one of the longest narratives of harm: leadership by complaint and intimidation.

A line of hope that might not be recognized when speaking of a pastor dominating a congregation, is that Pastor \#4 also stepped in at a crucial time in the life and history of the congregation and is responsible for moving them forward. Prior to 1975, there had been limited movement and very slow growth in the membership. With the arrival of Pastor \#4 a dramatic increase in the membership is seen. What Pastor \#4 provided for RPRC was the understanding that they could grow and become a vibrant congregation. If Pastor \#4 had left in the mid 1980's he would have been the hero of the congregation. At that time he was well respected and would have fallen into the "five years and out" methodology adopted by his predecessors. He also would have left the power structure largely unchanged, and it is highly unlikely that it would have achieved any modicum of health.

Once the congregation had seen where they had been, and recognized the pathology of the past, the Interim Pastor invited them to look ahead to begin to dream, to develop a Vision Statement that would envision a new tomorrow that did not look anything like the past. The final step was to then make an action plan that allowed them to prioritize what had to happen first, name the most important activities, and identify what would allow them to move on to other areas. Here the reality of congregational involvement finally began to take hold. Here the congregation became energized as they recognized for the first time in their life that if the congregation were to grow and thrive it depended more on them than on the pastor. They also understood the next pastor who 
came would need to measure up to their standards and assist them in reaching their vision, not the other way around.

When I began to serve, the mandate was given to me to implement a process and program to encourage lay participation and involvement. The goal was to help the membership of the congregation understand their spiritual gifts and how they could actively serve within the life of RPRC. This emphasis has led to two major developments documented earlier, the Mothers of Preschoolers program and the Family Education and Counseling Center. Both of these are ministries were developed or suggested by members of the congregation. My involvement has been largely that of supporting and encouraging these ministries, at least in the early stages. With the MOPS program I offer a supporting role and encourage the leadership; in the counseling center, due to the nature of that ministry, I have to take a more active role as director. What also must be kept in mind is that the inception and driving force for both of these ministries remains within the lay leadership of the congregation itself. My role in both of these has been that of facilitator, while empowering the members to exercise their gifts and talents in ways that had not been possible before.

While those are the two most visible aspects of a changed ministry and direction, a more vital and essential shift has been in new member recruitment. As I looked back through the Consistory minutes, through the process of interviews and even in informal conversation, prior to the arrival of the Interim Pastor the responsibility for new member recruitment rested solely on the shoulders of the pastors. When the congregation did not grow, no one bothered to see if the membership was inviting or even welcoming to new people. No one bothered to ask if the members were engaged in any form of evangelism, 
either formally or informally. When the congregation was not growing, a new pastor was sought, who was hoped to be a better "draw" for new members.

When I arrived as the pastor, I made it clear that the vision statement they had in place was the one I would work with. I also assured the congregation that this was their vision and I would work alongside them to implement it. I would not do it for them, nor would I unilaterally change it. What I emphasized from the day I arrived is that I saw ministry as a team effort and not a one-person operation. As a direct result the membership numbers increased quickly after I arrived then leveled off, but in the past three years average worship attendance has surged 30\%. While the early surge could be attributed to curiosity, the latest direction is attributable to my efforts to empower the congregation to do its own ministry.

My role has been in empowering people for ministry and encouraging the membership to do what they do best: reaching out to their friends and people they meet. When I do have the opportunity to talk to people about joining the church, they tell me about how many friends they have attending RPRC who invited them. My name is rarely on that list. What has taken place in the past ten years is a shift from a pastor-focused congregation to a diversified ownership of ministry. No longer does the life and vitality of the congregation depend on the pastor; it is now a shared responsibility in all areas of ministry. While I may have taken that to an extreme in not sharing my vision and dreams for the life of the church, the congregation has taken ownership of the ministry in ways they had either never done or been allowed to do in the past.

The key to moving toward health was not found in a packaged program or even an outline developed by a group of church experts. The key toward health was found in a 
man who came and sat with the congregation long enough to learn where the hurts were, who stayed long enough to help them work through their pain, and then enabled them to regain a sense of purpose and future once again. A second key component and equal to if not more important than the development of a Vision Statement was the ability to restore the task of ministry to the congregation. As I noted earlier, the Interim Pastor joked that he spent the first six months with his feet on his desk!

My role has been that of an encourager and supporter of the people who owned the ministry here. To demonstrate their ownership I have taken several direct steps. One was the establishment of Ministry Teams. These are teams of people directly responsible for various aspects of the ministry of the church. For instance, there is a team that is responsible for Christian Education, one for worship and music, etc. These teams are responsible to the Consistory, but they are empowered to make decisions and do ministry. For a couple of years I encouraged the ministry teams to meet every other month alternating with the Consistory to emphasize ownership of the ministry by the congregation, not the consistory or the pastor.

While our experiment did not last beyond the eighteen months, what has happened is that the leadership structure has become very flat. Now, instead of seeing a hierarchical leadership structure with the pastor atop the pyramid, what is seen is a very flat structure, with the pastor as a leader among leaders.

Another way of phrasing our leadership style and development here is that leadership has become functional rather than positional. Now, instead of revering the pastor merely because I hold the title, my authority has been achieved by demonstrating 
my ability to lead and empower other leaders. My authority is not derived from my ordination or title, but rather in the demonstration of my abilities.

While this leadership style is now being described in current church development literature, I learned this first hand in my role as a volunteer fireman. One afternoon we had responded to a routine call and I happened to be the driver of one of the trucks. Driving a truck down the road takes a little skill, but not a great deal of effort. Backing up that truck is another matter all together. As is customary in fire departments, our trucks are always backed into the station to allow a quick departure. After the call, I pulled up in front of the station and proceeded to back my truck into it's bay, when I heard the man next to me exclaim: "I'll be... the Preacher can back a truck!" From that day on I was accepted into the department as one of the "guys."

My acceptance was not based on my abilities to exegete scripture, or lead a meeting. My acceptance was based on a simple task that involved backing a truck through a garage door. Acceptance was based on my ability to do the job.

What I have done to further these efforts was to utilize the training in Gift Based Ministries using Network: The Right People...In the Right Places for the Right Reasons by Bruce Bugbee. ${ }^{168}$ What Network does that no other gift based ministries material does, is to encourage experimentation in ministry opportunities. In many churches assuming a ministry position becomes a life-long commitment, while Network encourages a short-term trial and error approach. If one aspect of your choice does not work out, try something else, no guilt or shame involved in not staying with a ministry for a lifetime. What this has allowed the congregation to do is to develop many short-

\footnotetext{
${ }^{168}$ Bugbee, Bruce; Cousins, Don; Hybels, Bill; Network: The Right People... In the Right Places for the Right Reasons. Zondervan Publishing House, Grand Rapids, MI; 1994.
} 
term opportunities. People are free to experiment, and if the ministry is a fit, they continue; if they find a mismatch, there is no dishonor in leaving it behind. Not only are people discovering their spiritual gifts, but they are learning they can do ministry in effective ways and are changing not only the church, but the community around them. To fully appreciate and implement this kind of ministry, it also demanded that the leadership of the congregation including myself as the pastor to be able live with the ambiguity of people shifting in and out of ministry assignments. The challenge here is that the congregation and leadership stop trying to fill slots, and instead encourage people to discover where God is at work and then join him in that effort.

While it is difficult to draw cause and effect from one program, by using this program immediately and teaching the core leadership group the value of gift-based ministry, it would seem that this has enabled the congregation to continue to move toward accepting responsibility for ministry. This same program had been attempted in a previous congregation, but it was taught as a Sunday school class and did not have much of an impact on that congregation. By following the guidelines given in the Network Implementation Guide I have been able to guide the congregation in a direction that enabled and empowered them to take responsibility for mission and ministry.

A second key development in the life of this congregation occurred following the Refocusing process. During a discussion with one of the Regional Executives, he suggested looking at a book and study by Henry Blackaby and Claude King entitled, Experiencing God, Knowing and Doing the Will of God. ${ }^{169}$ I introduced this to a core group of the congregation and then lead a twelve-week study of this material, which

\footnotetext{
${ }^{169}$ B lackaby, Henry T. and King, Claude V.; Experiencing God, Knowing and Doing the Will of God;
} LifeWay Press, Nashville, TN; 1990. 
exposed the group to a different way of thinking about the will of God. Blackaby's basic premise follows the same lines of the Refocusing material that God is always at work around us, and our task is to join in that work. This material also seems to have moved the congregation closer to an understanding that they could do ministry themselves. The direct result of this study was the founding of a second Mothers of Preschooler's group for working mothers that meets in the evening. Beyond this one incident has been a greater understanding of the need of the congregation to be engaged in ministry together.

As I evaluate my own approach to ministry, I find that I have habitually taken what in counseling is called a "one down" approach. That means that I approach the congregation, and the members of the congregation, not as the one who knows everything, but rather as a learner. This applies to all avenues of the congregation's ministry and mission. When a prospective congregation has asked me what my vision for the church would be, I defer. I always say, "I am not a part of your congregation yet and I am not in position to dictate where you should go." I have also adopted that same approach when it comes to suggesting curriculum or programming. It is my firm conviction that God has a unique process for every congregation, as well as a unique vision that can only be discovered together, not imposed by someone on the outside. By taking that approach to ministry I find that the members of the congregation are encouraged to try new approaches to ministry efforts and when they are supported by the pastoral leadership, more ministry is possible than trying to do it myself.

Today, the congregation has taken great strides toward facing its narratives of harm and building on the lines of hope present in the history of RPRC. Today, the congregation is once again on the verge of another building proposal. The difference this 
time is the narratives of harm have been addressed. I am now serving as the facilitator, not the initiator of the project, and there appears to be broad-based ownership of the plan and design of this addition. If the congregation is willing to take the step of faith that will be required to move the ministry to the next level of commitment, it appears that they will continue to experience growth and vitality. The danger still exists that the narrative of the old building project failure will be revisited. At least at this point in time that old question or the old narratives have not emerged and the possibility of moving forward with expanding ministry seems to be encouraging.

In every way this is an unfinished story, and it will not be completed until Christ returns. Until then, the congregation continues to plan to grow and expand. Building on the third group that was identified in the Refocus Summit \#2, there are plans to establish a second congregation that will utilize the same structure as the current congregation. The desire comes from two fronts. First is to remind the congregation that this is a "mission focused church," and this addition is not just for us. The second emphasis is to increase the number of worshippers to enable the congregation to achieve its dream. The second church will reach a different population and meet at a different time in the weekly schedule. The dream is to nurture the new congregation for a few years until it is strong enough to stand on its own, and then send them off to a new location. Ideally, the two congregations would continue to share office space and office equipment. When the second congregation is "off site," the plan is for RPRC to begin a third congregation. At the same time, the new congregation begins to look at the community and makes a decision to plant a daughter congregation itself. In that way, the message of health and reproduction will continue, and the Church community will be enriched as new 
communities are formed to reach succeeding generations. That will be the ultimate test of health. At the moment the question still remain, what will eventually win the day: the lines of hope or the narratives of harm? It is an axiom of the Natural Church development people that healthy organisms reproduce. While the congregation looks and acts healthy, the final test will be the ability of the congregation to reproduce itself. At the moment the lines of hope that were nurtured through the history of the congregation appear to be strengthening. An awareness of the need for the laity to continue to take ownership, is gradually emerging from succeeding generations of members. Will the new congregation become a reality? That will need to be saved for another project at another time.

\section{Summary}

By tracing the lines of hope through the life of the congregation I have really done little more than identify the successes that were present in the life of the congregation. The power in identifying these is that the congregation begins to see that they had been doing a large number of things that were positive and, despite the division in the congregation, God was still at work.

Tracing the lines of hope has also directly benefited the ongoing life of RPRC as at this present time the leadership is considering planting a congregation within the church facility. The concept is to establish a second congregation with a different mission and vision that would utilize the facility at a different time from the existing congregation. The purpose being two fold: 1) In the building process it becomes easy to see a new building as being only for "us", this keeps the focus on others. 2) It enables the 
congregation to reach a goal that was established during the Refocusing process, that of reaching people very different from them. In this discussion one leader began to question if the "congregation" would allow this to happen, and I pointed out that they most certainly would as they have been in the practice of "using" the building to give life to other organizations since the early days of its life. That ended that discussion.

Merely tracing lines of hope and narratives of harm is not enough. What remains to be covered in the next chapter is how these two intermix and often confuse those who are seeking to discern the larger meaning in each of these story lines. 


\section{Chapter Four}

\section{Contraindications Of Harm and Health}

As I suggested in the introduction, identifying the narratives of harm and the lines of hope is not always simple. Interwoven into the narratives of harm are lines of hope, and mixed with the lines of hope are the seeds of the next narrative of harm. This thinking is reminiscent of the work of George Vaillant whose book The Wisdom of the Ego details the defenses people employ to handle their personal shame. ${ }^{170}$ In that book Vaillant references multiple defenses and warns his reader that he is not implying that all defenses are equal, for as Vaillant also notes immature defenses are the building blocks of personality disorders. ${ }^{171}$ In the same way, not all lines of hope are helpful, and not all narratives of harm lead to destruction. Or to put it more poetically, it is often hard to tell who is wearing the white hats in the narrative of a congregation. In this chapter I want to pull together the themes that emerge from this case study and the possible lessons that begin to develop from this account of RPRC. Mixed within the themes are the hopes and fears of the congregation as well as those who were responsible for its supervision and ministry. As these lines of hope and narratives of harm intermingle, the shades of gray will begin to be apparent.

One theme that may not be immediately noticeable is the successful Interim Pastor. Twice at significant moments in the life of the congregation an Interim pastor was brought on board. The first interim was labeled as "Stated Supply," and generally speaking, his role was that of providing a regular preacher on Sunday morning to keep

\footnotetext{
${ }^{170}$ Vaillant, George E., The Wisdom of the Ego; Harvard University Press; Cambridge, MA. 1993

${ }^{171}$ Ibid., 45.
} 
the doors open until the next installed pastor could be found. What seems to have happened is that he allowed the congregation to transition out of a conflicted situation, either with the founding pastor or families and situations in the community to become a growing congregation. Shortly after the second pastor arrived, the congregation resumed a normal or at least a healthy rate of growth that encouraged the Classis, allowing the congregation to continue and gave sufficient hope that a successful congregation would result from his efforts.

The second interim pastor would arrive many years later, but like his predecessor the second interim arrived following a conflict within the congregation. The second interim was given much more flexibility in terms of assisting the congregation, and was even tasked with helping to restore the congregation to vitality once again. Like his predecessor, he left RPRC in much better shape than when he came. Following his efforts, the congregation has been able to grow and develop in a healthy and vital manner.

That makes me wonder, what makes a successful interim? Were these two men incredibly gifted and talented men? I can only speak of the second as the first interim has passed away. The second Interim moved from Yankton to attempt to plant a new congregation, which never made it past the initial phases. Following that assignment, he served as an interim at a second location, and by his own admission was not as successful there as he had been in Yankton. Today, he struggles to serve an older established congregation. What was different about RPRC that allowed both men to be successful? The key ingredient in both situations is that the congregation recognized a need for change and was willing to listen to an "outside" consultant to bring about that change. 
The second interim almost did not get the opportunity, except that two elders stood firm in the desire to bring in an Interim Pastor following the departure of Pastor \#4. Since leaving Yankton, the second interim has encountered congregations that were still blaming someone else or something else, and no one had taken responsibility for the problems within the congregation itself.

The key to a successful interim in this situation, and in any situation where an interim is placed, is the willingness of the congregation to accept responsibility for the problems within, rather than blaming the former pastor, members who left, or whoever the scapegoat might be. Until the congregation is willing to accept that responsibility, interims will be ineffective. [This is the key to any renewal process. The congregation must be willing to accept responsibility or understands the need for change.] Both times Yankton RPRC has accepted the guidance and direction of its Interim Pastor willingly and with great success. The key to their success has been in the willingness of the congregation to accept the direction offered by these men. This acceptance of their part in the creation of the problem in the first place, combined with their readiness to accept direction, resulted in positive movement. The same lessons apply to the larger denomination. Until the group stops blaming outside forces or looking for an outside savior and recognizes and accepts responsibility for the problems that are present, nothing will change. As in this case study, real change demands the involvement of the people who are being asked to change, or at least a sufficient cadre of the leadership of the congregation. What both RPRC's Interims found was a congregation and leadership at different times in their life struggling for survival and recognizing the need for major changes in the way the church was being lead. 


\section{The Power and Presence of Teens}

A second theme that emerges and confounds the observer is the power of the youth ministry within the congregation. It is confounding from the standpoint that children and youth usually tend not to thrive in a top-down leadership environment. The first place the power and presence of teens is seen is in a strong emphasis on children's choirs. Two children's choirs have existed throughout most the life of the congregation. In fact the congregation historically has been able to present rather elaborate Christmas musicals, and the history of musical groups is one of the hallmarks of the congregation.

The work with youth did not stop at children's choirs. The interest in youth ministry is also seen in an interest in hiring a youth worker early in the history of RPRC, and it also seen in the development of The Place. This emphasis and focus on youth is also seen in the existence of both Boy Scout and Girl Scout Troops that have been sponsored by the congregation.

Given the evidence of a top-down leadership that was present in so much of the life of RPRC, several questions come to the forefront. Did these "youth and children's" ministries develop outside of the normal channels of leadership? Were they evidence of an underground leadership that found ways to evolve even in the midst of strong or dominating pastors? While it is difficult to see what was really going on from this distance, I do know that the Boy Scout Troop that is still in existence benefited from a long term Scout Master who served the Troop for 35 years before retiring. I am also aware that Pastor \#2 began the Troop and initially served as Scoutmaster, so that connection militates against an underground or subversive component. What seems to be 
present in the life of this congregation is almost a parallel structure of strong lay leadership, along with an expectation that the pastor be in charge.

Even today it is not uncommon to see members serving many years teaching Sunday School or leading choirs. Further evidence of the congregation's commitment to children and youth is the large percentage of young families who have joined RPRC in the past five years. Where this shows up most dramatically is during the children's message in the morning worship when an average of 25 children under the age of ten crowd around the pastor. It is not an exaggeration to state that the congregation's value is placed on children and what they bring to the congregation.

The question that remains unanswered is how did these focuses on children and youth thrive in an autocratic environment? While the pastors were caring and dedicated men, there was an expectation of top-down leadership that should have hindered and impeded this kind of focus. The only explanation that I have been able to see is that alongside the top-down leadership was a cadre of lay leadership that was allowed to exercise their gifts, often outside the "normal" lines of leadership. It also lends evidence that lay involvement has a long history in a congregation that supported and even demanded a strong pastoral leader.

This top-down leadership has been identified as a narrative of harm. But this emphasis is not a one-way street. There is an old adage in family therapy, which says: "It takes two to make a monster. One who is willing to be one and one to help make them into that monster." Applying that proverb to the congregation, soon muddies the waters and makes it difficult to affix blame on any one person or any particular group of people. While the congregation does indeed appear to have been dominated by the 
clergy, particularly during the tenure of Pastor \#4, there was also a leadership cadre in the congregation that allowed this to develop or even encouraged it. While the laity encouraged and even supported a strong clergy leadership, they wanted to make certain that the pastors knew who was really in control, and to remind the pastors they were merely hired hands. So when the pastors did not follow the direction the group of lay leaders had set, the effort was put forth to remove that pastor. Once again borrowing family systems terminology, what developed was a system that was in many ways codependent. The lay leadership wanted to the pastors to take charge, but not too much, and when the pastors did lead, they were criticized for leading in the wrong direction. During the interviews I learned about this 'critical cadre' who criticized every pastor who had served RPRC. The thesis was supported by the comments of one woman I noted earlier who said Pastor \#4 just wouldn’t leave! While the pastors left repeatedly, nothing changed until Pastor \#4 outlasted his critics. Even his tenure has a mixture of narratives of harm and lines of hope. If he had not outlasted his critics, the congregation would never have reached its potential; it would have been trapped in a small membership mindset controlled by unhappy people. It is only due to Pastor \#4's staying power that the congregation spilt, though it has taken ten years to recover.

\section{Confronting Co-Dependency}

One lesson that emerges from this unfortunate time is that co-dependency in families or congregations must be confronted before it can be dealt with. If Pastor \#4 had not had the tenacity to persevere through increasing pressure for him to leave, or if he had not been as focused on the original vision of growing a congregation, the co-dependent 
relationship would never have been broken. It is out of this brokenness that health was able to emerge through the efforts of the congregation and the Interim Pastor.

Another unusual narrative of harm is the theme of recurring goal setting sessions. Normally goal setting and "vision casting" are seen as signs of health and vitality in the life of an organization. In this case study these goal-setting sessions were never effective. The leadership of the congregation would make a great deal of effort to bring in an outside resource or work through a process to set goals for the coming year or more, only to have nothing more said about these goals. While many reasons could be offered to explain the failure of these goal-setting sessions, the one that is most apparent is that someone outside the normal life of the congregation directed most of these efforts. One of the first goal setting sessions seems to have been initiated by the Classis or the Synod. Also, a synod executive lead a second event. Because these efforts were not initiated by the congregation nor were felt needs within the congregation prompting these sessions, they failed to achieve the desired results. Having led a number of these efforts, the normal response is to generate a lot of paper that is promptly filed away and forgotten.

The major reason these goal-setting sessions would fail is that the congregation looked at what had been done and tried to project their own ideas into the future. The missing component in these sessions seems to have been that no one stopped to ask the question, what does God value? It appears that the leaders or the congregational leaders themselves did not take the time to evaluate where God would have the congregation go into the future. The preferred future that was driving the congregation was their own projection of their anxieties and worries, not what would God have them to do and to be. 
The first time a goal setting plan or format would actually be effective and be implemented would be during the tenure of the Interim Pastor. What was lacking before that was an empowered lay leadership to own the goals. Prior to the second Interim Pastors, the expectation of the congregation was that the pastor would implement the goals. The result was a lot of paper and effort resulting in no change. Most of these pastors were struggling with a host of other expectations and job roles and were unable to fulfill even one more expectation or implement one more program or goal.

While generally goal setting sessions can be seen as a sign of health, personal experience and this congregation's record reveal that often goal setting is just one more way to avoid actually getting involved in ministry. Before goals and ministry can be effectively implemented in the life of a congregation, there has to be a lay leadership that actually feels they can make a difference in the leadership of the congregation. Without that sense of ownership, goal setting will never accomplish what it was intended.

As I noted earlier, I, too, was guilty of just such an effort prior to the Refocusing process. Fortunately, I have learned from past mistakes, and no longer operate the way I used to. Currently, when we need to establish new goals or refine the vision, the congregation holds what I call a mini-Refocus process. Instead of asking what goals do we want for the coming year, the congregation is invited to an evening of prayer and planning. The format allows the members of the congregation sufficient time to dream about what they think God might be leading them to do. This is followed by a time for personal and collective prayer, where the goals and ideas we have just developed are prayerfully considered. Following this time of prayer, if any decisions need to be made, a process of positive voting is followed. Positive voting involves giving every participant a 
limited number of self-adhesive dots. These dots represent their votes; they can vote for any goal or project they desire or put all their votes in one area to make sure it is an approved goal for the coming year. When the voting is completed, the goals with the most votes or dots are passed on to the various ministry teams for implementation. The key to the success is that the tasks are identified and then given back to those who set the goals to implement them.

The major difference between the ways the Interim Pastor and I led the goal setting processes and the way it had been done in the past is that we have focused on empowering the leaders. As I look back at the previous processes, and the one I attempted early on, they all depended on someone else to help develop the goals. By delegating the authority to set goals to the people who will have to implement them, the goals that are developed are then owned by those who set them; the goals are not imported or brought down from "on high." Where there is ownership, there is also the desire to implement and execute those goals.

While the Interim Pastor and I have taken great steps toward empowering the leadership of the congregation, we also took the essential step of inviting the leadership to ask the key question: "Where is God leading in the life and ministry of this congregation in the future?" As the Refocusing process points out, unless we do that, we will merely project our preferred values forward and never actually change. This seems to have been the missing ingredient prior to 1995 . 


\section{A Shared Building}

One line of hope that might not be immediately obvious is how the congregation has utilized its building over the years of its existence. Early in the history of the congregation, the Consistory voted to rent part of the building to a Nursery School. ${ }^{172}$ This was followed in 1965 with the establishment of Boy Scout Troop 133, and later a Girl Scout Troop. What is not found in the minutes is that for many years one of the women remained an adherent has used RPRC for musical recitals, both vocal and instrumental. Additionally, the Nursery School was eventually renamed a Pre-School and continued in the building until a few years ago. At the present time, the congregation is sponsoring two Mothers of Preschoolers groups, one daytime group and one evening group. The most recent emphasis finds RPRC providing space to the Family Education and Counseling Center, and while it is the most directly connected ministry that the congregation has sponsored, it too is a separate, non-profit agency. (This separating exists primarily for insurance purposes).

This building utilization could be seen as "subcontracting" ministry to outside groups, or a healthy willingness to share the building rather than hoarding the space and allowing the building to remain vacant six days a week. This willingness to share the building is most evident when a before and after school program known as Just For Kids (JFK) needed a new space. When one elementary school was no longer be able to host the program on site, I called the chairman of the Deacons and the Vice-President of Consistory and with those two phone calls RPRC arranged to host this program on a week's notice. This allowed the children of that school a safe place before and after

\footnotetext{
${ }^{172}$ Minutes of Consistory, December 29, 1964.
} 
school for that school year. It also sent a message to the community that this congregation was not afraid to use its building.

The willingness of the congregation to allow other groups to use the building demonstrates a congregation that had little pride in ownership of the building. For a long time that was a negative value as well. For when I arrived, the evidence of 30 years of neglect was very evident. While that was true, it was also true that major strides had been taken to begin to correct that neglect. Today, while the building is over 40 years old, it is well maintained and there is a regular schedule of maintenance and upkeep taking place. The legacy of a shared building also makes the failure of the building proposal under Pastor \#4 appear to be a power struggle rather than a building division. The proposal that was developed under Pastor \#4's tenure was a multiple purpose building that would allow the congregation to provide more recreational opportunities for the community, as well as to expand their own ministry space and opportunities that were lacking in the current facility. In many ways, Pastor \#4's vision was too far ahead of the congregation, and consequently Pastor \#4 got too far ahead and was mistaken for the enemy.

\section{Conflict and Community}

The final area of the complexity of the lines of hope and narratives of harm is woven around the ability of the congregation to disagree and remain in community. One of the amazing things I learned from interviews with former members, that many of them maintained good relationships with the pastor, despite leaving RPRC due to disagreements with him. Even after Pastor \#4 had left the community, he and his wife 
regularly visited these couples and even stayed in their homes while visiting in Yankton. Even those members, who would eventually have to confront Pastor \#4 about his leaving, continued to remain friends after this difficult time. What is astounding is that despite the conflict and pain, many maintained good relationships with the Pastor whom they had disagreed with.

The ability to contain conflict and remain in community was not just a legacy of Pastor \#4, for that remains the legacy of the congregation today. One elder who has served with me as Vice President of Consistory often visits with me about an issue that he has, and while we do not always see eye-to-eye on, we remain good friends. This is also evidenced in the return of several members who had left during the tenure of Pastor \#4. These returning members have been welcomed back into the community and made to feel welcomed once again.

Looking at this theologically, the congregation that is RPRC has learned how to extend grace to each other and has learned to live with the tension inherent with living in a community. Biblically, this concept is reflected in the first Jerusalem Council in Acts 15. ${ }^{173}$ In that incident while there was sharp argument and debate, the early Church found a way to agree to disagree and to work together.

From a therapeutic or systemic viewpoint, it also indicates a low level of anxiety in the system. This was not always a part of the life and history of this congregation. The history of RPRC shows a lot of anxiety about various developments at several points in the life of the congregation. This anxiety came to a head when the building proposal in 1989. Here, the lines of hope and narratives of harm begin to blur. As the congregation

\footnotetext{
${ }^{173}$ Acts 15:1-29. The occasion was the debate over circumcision and Gentiles being forced to obey the Law.
} 
split, it provided an opportunity for healing and renewal of hope nearly six years later. The lack of anxiety about the future and who the congregation is remains a significant part of the life of this congregation. At the same time the ability to remain in community despite conflict, that previously been experienced on an individual basis, has now moved to the leadership of the congregation. This healthy sense of community allowed the membership to develop a much more appropriate view of their role in the congregation and the role of the congregation in the community. The newfound sense of identity did not emerge out of a vacuum. It emerged from conflict and the tearing apart of a congregation that nearly ended the pastor's career.

The story of Riverview Park also demonstrates that renewal is never an easy process, nor a predictable one. This story also reveals that RPRC is still in the process of renewing. There is no one pattern or program that be applied to every congregation across the denomination. If the RCA is serious about local church renewal and revitalization, it will need to invest considerable time and money into the training of professionals who can spend the time to evaluate an individual congregation and then empower them to make the needed changes. 


\section{Chapter Five}

\section{The Refocusing Process As a Tool of Renewal}

This chapter will compare and contrast the Refocusing Network System published by Church Resource Ministries ${ }^{174}$ (CRM) with the process followed by the Interim Pastor at Riverview Park ${ }^{175}$.

When CRM chose to label Refocusing a system, the reader or would-be helper is given the impression that this is easily used to achieve consistent results in any congregation across the nation. That assumption is one of the major fallacies of local church renewal. Closer to the truth is what CRM identifies as a reproducible process. Refocusing is a systematic approach to renewal and revitalization, but not so systematic as to function the same way in every congregation. Nor is it designed to be used as a "cookie cutter" to reproduce the same kind of congregation in different parts of the world.

Before I say any more, I think a word about the difference between a process and a program is in order. My definition of a process is an outline that allows the user to modify and adapt the flow of the material or the approach to fit the needs of the particular audience or community. On the other hand a program has well defined approaches that must be used the same way in every situation. Where a process allows for variety, programs demand uniformity. While Refocusing allows for reproducible processes, it also allows the individual congregation to tailor the process to meet its needs. For instance, at RPRC the congregation already had an existing mission statement, thus only

\footnotetext{
${ }^{174}$ I am using the 1998 Manuals, as those are the most recent ones accessible to me. It is important to note that CRM views these manuals as open to revision at anytime and the comments made here reflect that process I was trained to us, not necessarily the process as it is today. Although some revisions have been made, the basic principles remain intact.

${ }^{175}$ For a side by side comparison see Appendix \#5.
} 
cursory work was done on the existing statement instead of writing a new one as the workbook suggested. A second modification came in the area of a ministry flow chart where the leadership adopted a novel approach rather than one suggested by the workbook. The major distinction I make between process and program is that processes allow flexibility, while programs demand uniformity. It is my conviction that church renewal will always be a process that will have to be adapted to meet each church's unique setting and needs.

The renewal process proposed by CRM is anything but a system that should or could be applied wholesale in every congregation. On the contrary, this process, as it is written, is applicable only in a narrowly defined constellation of congregations. In section nine of the year one manual is a section labeled "The Four Rs of Revitalization." congregations that should be considered as candidates for the Refocusing process contained in his manuals. The means used to measure the congregational readiness for this process is the Natural Church Development (NCD) profile. ${ }^{177}$ The NCD material is based on the research of Christian Schwarz into what he calls the "biotic principles" of congregational health ${ }^{178}$.

While the specifics of Schwarz's research are beyond the scope of this project, suffice it to say that the NCD survey which leads to the NCD profile is an objective measure of congregational health. In developing the Refocusing process, Walling chose

\footnotetext{
${ }^{176}$ Walling, Terry B., Focusing Leaders, Phase one of the Refocusing Network System; ChurchSmart Resources, Carol Stream, IL; 1998. Tab 9, Momentum 3.4.

${ }^{177}$ Schwarz, Christian A. and Schalk, Christoph; Natural Church Development Survey; available from ChurchSmart Resources.

${ }^{178}$ Schwarz, Christian A. and Schalk, Christoph; Implementation Guide to Natural Church Development; ChurchSmart Resources, Carol Stream, IL; 1998.
} 
the NCD survey as a means to allow the user to determine if a particular congregation is able to utilize the material as it is written, or if another kind of intervention is necessary to accomplish the task of renewal/revitalization.

\section{The Four Rs of Revitalization}

Walling defines "The 4 Rs of Revitalization" as Resourcing, Refocusing, Restoring and Rebirthing. The first " $\mathrm{R}$ " stands for Resourcing. A Resourcing congregation is a congregation that finds that when the NCD survey is taken, the scores reveal that the group is relatively healthy. This is determined when most of the scores on the eight biotic principles of the NCD profile are at or above a $65 \%$ quality line. ${ }^{179}$ According to Walling, a congregation with this level of health would benefit from some outside consulting to help them raise their low score areas. However, due to the relative health, this congregation would not be a candidate for the Refocusing process.

The second " $\mathrm{R}$ " stands for Refocusing. A congregation in this category would find most of the NCD scores below the $65 \%$ quality line with a few near the $30 \%$ level. This type of score is representative of a congregation that has plateaued and would benefit from the Refocusing Your Church, strategic planning process.

The third " $R$ " stands for Restoring. A congregation falls into the restoring category when most of the scores from the NCD survey fall at or below $30 \%$. This is indicative of a congregation with significant weaknesses and it could require an intentional intervention process, often involving an outside consultant and usually requiring substantial work. Generally, this congregation would not be a candidate for a strategic planning process such as Refocusing. While a process like Refocusing could be

${ }^{179}$ See Appendix \#6 for graphics depicting this information. 
utilized, the Refocusing manual suggests a congregation in this category employ and outside consultant.

The fourth " $\mathrm{R}$ " stands for Rebirthing. When all the scores fall below the $10 \%$ $20 \%$ range, this indicates a troubled ministry that could require the congregation to be restarted. This congregation is definitely not a candidate for a self-led strategic planning and process such as Refocusing and most certainly requires an outside intervention. Most likely a congregation with scores that low would be a likely candidate for being completely restarted, as other revitalization processes are unlikely to achieve the desired result of a vital and growing congregation.

When the Refocusing Your Church process is properly understood and defined, it becomes clear that this material is suited for a small group of congregations with a specifically defined set of circumstances. When the Refocusing process is applied in those settings, like Riverview Park, the outcomes can be extremely beneficial. However, when the process is applied in a restoring or rebirthing congregation, the usual outcome is generally yet another failure. With each successive failure another narrative of harm is added to the life of the congregation that only reinforces the image that the congregation will never quite measure up to the standard that someone is holding up before the congregation.

Once the criteria are certain and the congregation proves to be a good candidate for the Refocusing process, it needs to be clear to everyone involved what this process can and cannot do in the life of a congregation and how it will work in the local church. One of the first principles of the process is that personal renewal precedes corporate renewal. Following that principle, Refocus begins with a pastor's network. 
A quick overview of the process indicates that Refocusing is at the minimum a two-year process that involves nine pastor's cluster meetings during the first year. Alongside the pastor's cluster meetings is a component that originally involved a series of four lay leaders meetings during the course of the first eighteen months of the process (This has now been converted to a weekend "Focused Living Retreat" that starts the pastor's networks and also provides an opportunity for the lay leaders to experience the same learning that previously spread out over three Saturdays). The emphasis in the first year of this process assists leaders in developing their own personal mission/vision statements, along with action plans and accountability groups to empower these leaders in personal renewal.

One weakness of the early formulation of this process was that only a small percentage of the congregational leadership participated in this personal renewal process. Later revisions suggest involving the entire leadership of the congregation in the Focused Living Retreat prior to the congregational renewal phase.

One of the strengths of the Refocusing process is the emphasis on training and empowering the lay leadership and the pastor of the congregation. A second key to the success of this process is that the pastor is not expected to lead this task alone.

Before the Refocusing process moves forward, the pastor must recruit a Refocusing team of men and women from the local congregation who will actually lead the process themselves. The pastor's role in the Refocus process is that of facilitator of the discussion and leader of the process, not the decision-maker. All the decisions are made in conjunction with the lay leadership team and the assembled leadership of the congregation. 
Once the leaders of a congregation have understood the importance and necessity of personal renewal, the process then moves into corporate renewal. The second year is dedicated to three large group meetings known as congregational summits. A summit is defined as a high place to take a look around, to gain a look at the terrain so one can return and go to work. The first summit focuses on the history of the congregation, essentially asking the question: "Where have we been?" The second summit focuses on a more contemporary question, "Where are we going?" The final summit asks the question "How are we going to get there?" During the time between the first and second summits broader congregational input is gathered through what are known as pulse groups. Pulse groups can be existing groups in the congregation or ad hoc groups assembled to give a broader input into this process. The key feature of this strategic planning process is involves including enough people to provide sufficient numbers to keep the vision from being the dream of just one person or even a small group of leaders.

Refocusing attempts to involve a critical mass of the leaders in the local church to own the vision, so that the new vision will find acceptance within the congregation when it is completed. The wisdom of this approach is born out in the research done by John Kotter in his book Leading Change. ${ }^{180}$ According to Kotter, one key to change requires utilizing more people than previously thought necessary to bring about the desired change:

In an organization of 100 employees, at least two dozen must go far beyond the normal call of duty to produce significant change. In a firm of 100,000 employees, the same effort might be required of $15,000 .{ }^{181}$

\footnotetext{
${ }^{180}$ Kotter, John; Leading Change; Harvard Business School Press, Boston, MA. 1996.

${ }^{181}$ Ibid. p. 35.
} 
By involving a large group of the leadership of the local congregation, the Refocusing process makes it possible that the changes being discussed will actually be implemented.

The final outcome of the Refocusing process is a broad based vision and action plan that can guide the congregation for the next three to five years. When done properly, these vision and action plans enjoy broad-based congregational support.

The preceding paragraphs outline the Refocusing process in broad strokes. In order to develop an accurate comparison between what the Interim Pastor did at Riverview Park and how it compares with the Refocusing Process, I need to give more detail into the summits. While I will be going into more detail, I will focus primarily on the tasks, rather than the exact details, to provide the needed comparison and contrast. Rather than developing a detailed analysis of the summits and then a commentary on how they were similar and different from the process employed by the Interim, I will offer that contrast in the midst of explaining the Refocusing summits themselves.

As has been noted, Refocusing is based on the premise that individual renewal precedes corporate renewal. While the Interim Pastor did not do anything specifically related to individual renewal, he did spend time building relationships and empowering the lay leadership of the congregation prior to focusing on the development of a vision statement. In the Refocusing process, as it has been revised, the beginning phase of the Refocusing process is a weekend retreat for the pastors of several local churches who are working in a cooperative network that enhances the learning of both the pastors and the lay leaders involved.

This leads to a second difference between these two processes. at Riverview Park the Interim Pastor by necessity was working with one congregation and its leaders. On 
the other hand, in the Refocusing process pastors and leaders from several congregations meet on a regular basis to encourage and troubleshoot difficult areas in the process. (At the time the Interim Pastor arrived, RPRC would probably have been classified as a restoring congregation and would have demanded this kind of outside consultation.) While the leaders at Riverview Park had the individual attention of one man full-time, the congregations in a typical network have the camaraderie of the shared experience of all the congregations in the network and consequently learn collaboratively. While the pastor's networks now begin with a "Focused Living Retreat," which condenses the former first four monthly meetings into a weekend format, the pastors continue to meet monthly with a trained coach to enhance their learning together and to be trained to lead the Refocusing process in their own congregations.

It usually takes the majority of the first year of the process for the leaders to establish their own personal vision statements and begin the process of implementing that vision in their own lives. Once the process of establishing a personal vision statement is accomplished, and then it is time to move onto the task of corporate renewal. In the second year of the process, the pastor's network continues as pastors meet together with a trained coach on a monthly basis.

Before the leadership of the congregation embarks on the leadership summit, a smaller team of leaders is trained to lead these summits at a weekend training seminar. There, these leaders largely experience the summit in a shortened form, while the person who is coaching the network explains the process. This type of learning enables them to better anticipate what kind of possible issues and problems they might face in their own congregation when leading these kinds of meetings. Once the "Refocusing Team" (as this 
group is now called) is trained, they and the local pastor will lead the Refocusing process in their own congregation.

The first summit is dedicated to asking the question "Where have we been?" This is not an individual question, but a corporate question. Since the congregation is a living organism guided by the Holy Spirit, the key question that is being asked is: "Where has God been at work in the life of the congregation?" To answer this question, the Refocus manual suggests covering a large expanse of wall in a meeting room with newsprint or butcher paper, and dividing that paper into regular increments depending on the age of the congregation. The leaders assembled at the summit are then asked to write a different event on each of five "Post-It-Notes." These events include both the positive and the negative events from the life and history of the congregation. The "Post-It-Notes" are then systematically placed on the newsprint developing a historical timeline that allows the leaders to begin to see where God has been at work in the life of the congregation.

At Riverview Park, the Interim Pastor did not use the formal process of assembling the leaders to ask the above questions. Instead, he informally visited the membership of the congregation to learn the problems and pathology of the congregation. While not exactly the same process, the Interim did construct, in his own mind at least, a history of the life of the congregation, at least from a problem-oriented perspective.

The Interim did something the Refocusing summits could not do and are not designed to do, and that is he allowed people to grieve the losses they had experienced. Since the Refocusing process is designed for relatively healthy congregations, one of the directions given to leaders in the training session is not to allow too much time to dwell on the negative experiences. While that may sound crass and even short-circuit the 
process, the leader's materials related to this summit, note that any difficulties the congregation encounters at this point of the process are most often related to denial. It is further suggested that if denial continues to persist, the congregation should consider abandoning the process and seeking outside help at this point. ${ }^{182}$ (Unfortunately, that advice is not made very clear in the instructions). If a leader/pastor tries to persist in a Refocusing process without dealing with the past pain or narratives of harm, the congregation is set up for failure. Unless the narratives of harm are dealt with, renewal through this process will be impossible. Instead of new health and vitality, yet another failure, another narrative of harm, will be written for that congregation.

The difference at Riverview Park is that denial was not an option. Everyone in the congregation knew a split had occurred. Everyone knew that the long tenured pastor had left, and everyone felt a loss. While they may not have been able to adequately process or grieve that loss initially, the Interim Pastor provided that opportunity and through the Refocus process the loss was acknowledged the loss and the congregation moved forward without much comment.

When reviewing the Refocus material, the issue of grieving and mourning losses needs to be kept in mind with the. As the Refocus process is written and developed, the process is designed for relatively healthy congregations. Based on my experience, RPRC would not have been suited for a self-led process. In order for this congregation to begin to return to health, it was imperative that an outside consultant led this process.

When the congregation is able to name the hurts and identify the joys, the process then moves on to making chapters from the events on the time line, and finally, to identifying the core values of the congregation. The process of identifying the core

\footnotetext{
${ }^{182}$ Walling, Terry, Presenter Resource Kit-8.
} 
values begins with affirming Biblical values, answering the question "what would God affirm?" Next, comes a hard look at the actual values, those values that are written on the history of the congregational actions, not in the collective desires of the congregation. At Riverview Park, the Interim Pastor identified the actual values, namely that the Pastor dominated and the membership followed. In the Refocusing process the leaders themselves are called on to be honest and name these values. When there is an ability to see through the values they wish were evident, the congregation can then move on and describe what the church actually valued. Once the leaders have owned their actual values, they are encouraged to develop a list of what they see Biblically as the principles God values. This second list is known as the preferred values. Those "preferred" values begin to form the core values for the church as it seeks to move toward health forming the basis for a different future.

The difference at Riverview Park, is a lot of this looking back at the past and evaluating what had taken place was conducted by a smaller group than would be used in a Refocusing summit. The Interim Pastor invited the Consistory to study Revive Us Again: Help for Stagnant, Stuck and Sterile Churches, by David Dethmers ${ }^{183}$ as a tool for looking back. In that study the Consistory was able to examine what had happened and then processed that experience in a safe manner.

The experience of RPRC under the Interim Pastor affirms that Refocusing is what it claims to be, a strategic planning process, not a program, nor the only program available to congregations. Refocusing is a tool that enables congregations to do the work necessary to regain health. The experience at RPRC also reminds the reader that no

\footnotetext{
${ }^{183}$ Dethmers, David; Revive Us Again, Help for Stagnant, Stuck and Sterile Churches; Reformed Church Press, New York, NY. 1994.
} 
one process is perfect for every situation. The core value, or the essential task when doing strategic planning and working on congregational health is to find a way to take an honest look back at the history of the congregation without evading the hard truths, and without adding another narrative of harm or layer of shame to the history of the congregation in the process. As the Refocus material notes, if a congregation shows resistance at this stage of the process, some deep-seated pain involved in the life of the congregation has to be addressed. That is best done using an outside consultant.

The truth is probably too difficult for most people associated with the congregation to talk about, but someone outside is able to surface the issues and then leave. This person in many ways becomes a scapegoat, taking the sins of the congregation with them when they go. That is what the Interim Pastor was able to do for the members of Riverview Park. He surfaced the pain, dealt with the deep-seated issues of a controlling pastor and a division, and then left, taking that pain along with him.

At Riverview Park, when the congregation approached the Refocus process about three years after the Interim Pastor had finished his work, the members of the congregation were able to easily discuss the past, even the pain of the split. They also easily identified the values they had evidenced during the past. There was no desire to escape the fact that the congregation had been through some pain, because they were currently experiencing some growth and were able to see the hand of God even in the midst of the painful experiences they had been through. This again was only possible due to the work of the Interim Pastor previous to the Refocus process. The one event that was not discussed in depth was the departure of Pastor \#4 and the congregation's involvement. His leaving was noted as a painful time, but nothing more was said, even though the 
Refocus Team had discussed the possibility of this being problematic and had already processed and developed a way to deal with this issue.

The final step for this first Refocus summit is entitled surrender. A graphic that is presented during this time reminds the leadership that the task before them is not to invent a preferred future, but to discover where God is already at work and then to join him in that work. Before a local church can move in that direction they have to surrender their own personal and corporate agendas. Therefore, the first summit ends with a prayer meeting where the assembled leaders of the congregation are encouraged to ask God for his guidance and wisdom and to allow them to lay down any plans and agendas they are bringing to this process.

While I am not certain there was a parallel in this process followed by the Interim Pastor, he did not really need to do that with this group. What the Interim Pastor found when he came was leadership so demoralized they had no agenda, and they were looking for someone to help them discover a preferred future.

According to the Refocus process calls pulse groups follow the first and second summits. The pulse groups are intentional small groups or natural small groups already existing in the congregation. These groups have two purposes. First the results of the first two summits are shared and even modified following input from a larger group of the congregation who were unable to be present during the summits. The second purpose of these groups is to not only keep everyone informed as to what is taking place, but to keep as many people involved in the process as possible.

What the Refocus process seems to have utilized is a theory of change management that suggests a concentric circle approach. According to this theory, a small 
group develops a plan or an idea and shares it with successively larger groups until the whole group has heard and been heard on the issue. Only then is the change implemented. The Refocus adopts that process, only beginning with a larger circle to begin with. By enabling more people to be in on the development of the goals, that enhances and allows congregational acceptance at the end.

While Summit one was dedicated to a look back, asking, "Where have we been?" Summit two asks, "Where are we going?" The first part of the summit includes a presentation of demographic data about the people who are part of the community where the congregation is located. The congregation is asked, "Who are the people in our ministry service area?" As a part of this summit the leaders are forced to examine whom they are currently serving, as well as, to ask the question "whom could we serve if we changed just slightly or added something to our ministry mix?" They finally ask the question, "If we changed radically who could we reach in our area?" (according to the Refocus notebook, the proper phrasing is that this group would need further prayer and discussion before it becomes a viable focus for ministry). ${ }^{184}$

From what I observed no similar process occurred at Riverview Park, in terms of determining a future focus. The mission statement that was in place when I arrived called for reaching out to families with young children and the elderly. One of the first tasks I had was to ask the Consistory was which group to focus on rather than trying to be all things to all people which would only dilute any ministry efforts. (The Consistory chose to focus on families with young children).

\footnotetext{
${ }^{184}$ Walling, Terry, Focused Ministry Resource Kit, Church Resource Ministries; Anaheim, CA. 1999. Summit 2: Discovering. P.8.
} 
Another key component of Summit two is the assignment to develop a picture of the future from God's perspective. The directions given to the group are this: "If God were to have his way, what could our "church" (both facility and congregation) look like three to five years from today?" 185 The groups are then given a large piece of newsprint and markers and invited to "picture" a different future for their congregation.

Once again I cannot find evidence of anything like this having been done by the Interim Pastor, except his invitation to ask the leadership to dream and imagine the future of their congregation. Their answer became the Mission Statement. Regardless of the form and the process, both the Interim Pastor and the Refocus summit two arrived at the same place: a Vision Statement that would guide the congregation into its preferred future.

The final summit of the Refocus process is to develop the action steps. Once the leadership and the congregation have discovered where they have been and where God is leading them, it is time to develop a plan on how to get there. This is where the process becomes difficult and sometimes breaks down, as the first assignment is to develop a ministry model. According to the Refocus notebook this step is important because it:

- Helps the church become focused and intentional

- Helps the church understand how various ministries work together

- Helps the church assess the need for various ministries

- Helps the church establish strategic of major ministry initiatives. ${ }^{186}$

(While that may be accurate and valid, this particular exercise created more confusion than clarity when I led two separate congregations through it.) The leadership of Riverview Park under the direction of the Interim Pastor seemed to accomplish the task they set out to do without this step. As a caveat, this kind of ministry flow chart is

\footnotetext{
${ }^{185}$ Walling, Terry, Ibid., Summit 2, p. 12.

${ }^{186}$ Walling, Terry, Ibid., Summit 3, p. 7.
} 
necessary when moving into larger and more complex congregational systems. At the moment all ministries have a committee assignment and the lines of accountability are easily seen.

While the Refocusing material has many nice charts and diagrams illustrating various ministry models, in the end, the leadership adopted none of them, and instead, drew up their own which can be seen in the Strategic Ministry Plan ${ }^{187}$.

Once a leadership team has defined their ministry plan, they are then challenged to develop a three to five year plan. Again this is similar to the process followed by the Interim Pastor. Both approaches yielded plans that had three month, six month, one year and three year goals, along with the action steps and a person or persons responsible for each area of ministry or work that had to be accomplished.

One of the significant strengths of the Refocus model is that each small group at the summit is invited to develop a set of three to five goals to be listed by the moderator. Once that list is generated, and it could involve as many as twenty goals listed on newsprint, every participant is given three colored self-adhesive dots to act as their votes for what they believe to be the most important goals for the next three to five years. One of the strengths of this kind of decision-making process is that everyone in the room has a voice; the decision is not left to the loudest or the most vocal to decide which initiative "wins."

While every "voting" arrangement has its strengths and weaknesses, I have been pleased with the way the positive voting has worked in my experience. The two processes I have led have been very positive and helpful in determining the top priorities for the congregations involved. This kind of decision-making also generates a lot of

\footnotetext{
${ }^{187}$ See Appendix \#4.
} 
enthusiasm for implementing the goals as well. My experience is not just limited to my own congregation as I have acted as a consultant for another congregation completing this process with a new pastor.

\section{Conclusion}

The two processes that have been compared are in reality very similar in the approach to the issue, but very different in the circumstances they can and should be applied to. The similarities are that they both asked the same three basic questions: Where have you been? Where are you going? And how are you going to get there?

What is different is how and who asked those questions. At Riverview Park it was imperative that a person asking these questions recognized that the group had been through a damaging time and needed help in healing by asking these questions. In the Refocusing process the basic assumption is that the congregation has a certain level of health and members are, therefore, able to successfully ask these questions of themselves and be able to answer them without losing focus.

Where this process will and does break down, is when it is attempted in the lower two levels of a Restoring and a Rebirthing scenarios. As the case study revealed, there are other resources available to use in those situations. What seems to be the most important factor, however, is not the material utilized, nor the ability and skill of the facilitator. The key variable is the willingness and motivation of the congregation. A congregation and leaders who are satisfied and comfortable will never want to do the work of the Refocusing process, or of any other change process for that matter. 
While I don't have any hard data to back up my assumptions, this accounts for many of the challenges the Reformed Church In America has had with this process. The RCA has attempted to utilize a process that is designed for a moderately healthy congregation and apply it across the spectrum of congregations. When a local church is in the Restoring or Rebirthing level of health, asking them to do strategic planning merely adds one more level of frustration to the congregation and reinforces the self-perception that they can never quite measure up. As was noted at the beginning, a Resourcing congregation does not need this process either; rather they need a consultation on a few specific areas.

Had the Classis allowed Riverview Park to attempt a strategic planning approach like this Refocus process after the departure of Pastor \#4, the outcome would not have been as positive as it has been for the congregation. Because the Classis and leaders of Riverview Park insisted that an Interim Pastor was needed to help heal and restore the RPRC, the congregation was able to successfully negotiate the strategic planning process three years later. It also earned the highest scores on the Natural Church Development Survey among the congregations in the Refocus Network at that time. What intrigued me was how could this congregation be the "healthiest"? At that point in time, Riverview Park was probably numerically the smallest congregation in the group. As I asked this question of my fellow pastors, we agreed that because the Interim Pastor had pursued a similar process, he had enabled the congregation to develop this level of health.

While the two processes are anything but identical, it is clear that local church revitalization does follow a pattern, and processes, not programs. The key to developing healthy congregations is the choice of the proper intervention and the ability of a leader 
who is able to use a variety of tools in those interventions. The process of local church revitalization is never going to be simple or easy. There is no simple way to restore a congregation, much less a denomination to health. What is required is the time and personnel to look at each congregation, much like a medical doctor examines each patient. When a thorough examination is complete, the doctor then looks into the accepted medical practices and chooses a prescription suitable for that patient. While the prescriptions may be similar among the patients, a good doctor takes the time to tailor the treatment to each patient. When it comes to working with congregations, those living communities where the Spirit of God is pleased to dwell, dare we do anything less? 


\section{Chapter Six}

\section{My Journey}

Earlier I borrowed a quote from Alice Miller and I want to do the same again: "Experience has taught us that we have only one enduring weapon in our struggle against mental illness: the emotional discovery of the truth about the unique history of our childhood." ${ }^{\prime 188}$ What is applicable to congregations is of an equal if not greater necessity for those of us who would lead them. Along this same line is a quote attributed to Socrates that "the unexamined life is not worth living", and for me that has become one of the realities I live with. My journey toward self-discovery began long before I embarked on this Doctor of Ministry program.

I would like to say this journey began in 1997 when I enrolled at North American Baptist Seminary in Sioux Falls, South Dakota to pursue a second Master's Degree in Marriage and Family Therapy. That would be true in some regards. But what it would neglect is the story of my life that predates that. To enable the reader to begin to understand the shaping of my life I need to provide a little historical background. What follows is an abbreviated autobiography. In the following chapter I will be addressing my own narratives of harm and lines of hope in a manner similar to what I have done with the congregation of Riverview Park Reformed Church.

I was born in 1956 to Robert and Margie Veldhuizen, in Bellflower, California. I joined my older sister, Karen, who was only ten months at the time. So into the perplexity of young marriage (my parents had been married less than two years when I

\footnotetext{
${ }^{188}$ Miller, Alice; p. 1.
} 
was born) and a young family, a second child came along to add to the family. What further complicated life for my parents at this stage of their life was that Dad had not finished high school, which meant job prospects were limited. Fortunately at this time, Southern California was the land of orange trees and dairies; it was in the dairy business that my Dad found his employment. One of the reasons Dad had moved to California to begin with is that an older brother owned a dairy and offered him a job milking cows. After a few years of milking, my father was able to find other employment as the manager of what was called "The Fertilizer Pile." The Fertilizer was the accumulated cow manure from many of the local dairies that was composted and sold as fertilizer. Then, in 1959 a third child, my younger sister Dawn, joined our family, and now we were five.

Adding a third child to the family meant it was also time to move to a larger home. So my parents moved across town to a larger home, with a large patio and brick fence around the backyard. Also during this time my father, who had dropped out of school after the $8^{\text {th }}$ grade, completed High School as well as Night School in Diesel mechanics. According to my Dad he tried college courses but never did quite understand how to write essays and papers, but happily he found diesel mechanics more to his temperament.

With a new diploma and new possibilities, the family moved from Southern California, and my mother's extended family, to the Central California town of Ripon near where Dad found employment as a diesel mechanic. Beginning in 1963, at seven years old, Ripon became my home and was the center of my life for the next eleven years. 
While Ripon was located geographically in the Central Valley of California, Ripon was a farm town of 3,500 people where everyone seemed to known everyone else, and small town values remained strong. Even though Ripon was located only 80 miles from places like Berkley and the Haight-Ashbury district of San Francisco, the town remained largely farms and small town issues. Ripon was also the place where many mid-westerners came to settle; following friends from Minnesota and Iowa, they settled in the community to find a new place and a new beginning. After all, California was still the land of opportunity for many people.

Even while many people were still responding to the call to "Go West Young Man," upon graduating from Ripon Union High School in 1974, I felt a call to pursue some kind of full time Christian ministry. Due to having been accepted at Northwestern College in Orange City, Iowa, I packed my bags and headed East to Orange City where I would spend the next four years. A number of highlights from my college career spring forward, but the two that stand out were meeting my future wife, Deb, and volunteering as a Youth Leader at one of the local churches for nearly three years. The year 1978 brought two major milestones in my life; the first was graduation, on May 15, and five days later on May 20 I married Deb, my college sweetheart.

After graduation and marriage, we spent the summer living along the Missouri River in a trailer her uncle owned, while I worked for her father on his farm. My fatherin-law tells me that was to help me understand what his world is like and so that someone in the family understood farming. The fall of 1978 found Deb and I heading East to South Hamilton, Massachusetts where I would attend Gordon-Conwell Theological Seminary. As with many seminaries I was required to seek out a Field Education 
experience. Since RCA congregations were scarce I called every local church listed on the seminary Field Education bulletin board and was turned down, as I was not a part of that faith tradition. Even though I had vowed to stay out of Youth Work following my college experience, the only opportunity available to me was working with Young Life. Young Life is a para-church youth ministry for High School students. So, despite my vow to move out of working with teens, I found myself back in the middle of High School youth work. One of the major concepts that Young Life employed in bringing the Gospel to teens was the emphasis on building relationships with the teens prior to sharing the Gospel. A lot of the ministry time was focused on being present in the High School, attending sports activities, or being with the teens in informal activities. Working in Young Life for those three years taught me a lot about the ministry of presence and the value of being with people to earn the right to share the Gospel with them.

Upon graduation in 1981 I was ready to begin my clergy career. Having spent the better part of the last six years working with teens, I was ready to engage a different kind of ministry. However the only position I was offered was a part time Youth Director position, which eventually became a $3 / 4$ time Youth and Calling Pastor position with the Trinity Reformed Church, in Kalamazoo, MI.

Over the course of the next eighteen months I worked with a veteran pastor and learned the basics of local church administration and preaching. In the fall of 1982, Deb and I found our family expanding with the birth of our first son named Andrew. In the spring of 1983, the Executive Committee of the Consistory told me that due to an uncertain cash flow situation, they would not be able to offer me employment in 1984; I was encouraged to seek a different position. With that in mind, plus the opportunity to be 
gone as often as necessary to search for a new position, Deb and I visited three congregations, in three states, in one six week stretch.

After a short search, we decided the place God was calling us was the Faith Community Church of Eddyville, Iowa. For the next six and a half years I served as the "parson" of the community and the pastor of the Faith Community Church. In Eddyville, I learned the value of community involvement. After living there for a year I was asked to join the volunteer fire department. When I protested I did not know anything about firefighting, I was told not to worry as this involved on the job training. While I would learn fire fighting, I learned even more, the value of the pastor being involved and engaged in the community. One lesson I learned is that I earned more respect in bunker, gear, as the pastor, than I did wearing a robe. In Eddyville our second child joined our family; our daughter Erin who was born in 1985. Eddyville also taught me a lot about being a pastor, and about grace. The congregation and community allowed this young pastor to make his mistakes and to learn from them. They supported and encouraged me, and at times corrected me.

The year 1989 found us moving once again, this time to the Bethany Reformed Church in Canton, South Dakota. According to the accepted wisdom of the day, this was a move up. Bethany was a much larger congregation, and for the members of both congregations, this was considered a promotion. As a young pastor, I felt the best way to succeed was to replicate my success in Eddyville, by doing the same programs and activities in Canton. Upon moving to Canton, I sought to visit every member of the congregation in the first year, and then I moved to community involvement. I became a member of the volunteer fire department, as well as an active member in the local 
ministerial association. When my son was old enough, I became a Cub Scout leader, and eventually, a Boy Scout leader. What I was not able to grasp is that while the communities were similar, the congregations were very different. Where the community ministry had been affirmed in Eddyville, the congregation in Canton saw it as a distraction. So after serving as the pastor the Bethany Reformed Church for over seven years, the elders informed me that my services were no longer desired and that I needed to look for other employment.

Where previously my departure had been economic or my own choosing, this was a personal rejection of my leadership and I felt of myself as well. During this time I was meeting with a "reading group" who had become a support group in whom I could confide. After telling them I was being asked to resign, one of the members suggested I put together a short statement about who I was in ministry and what I felt my strengths were. This would be my very first attempt at writing a mission and vision statement. Feeling rejected in an area where I had previously been affirmed also lead to a time of personal questioning about the desirability of seeking another Pastor's position. For a time I investigated the possibility of pursuing a Masters Degree in Marriage and Family Therapy which would have allowed me to pursue a career as a counselor, rather than as a clergy person.

In the midst of pondering the possibilities I was directed by the Synod Executive to submit my profile to the Riverview Park Reformed Church (RPRC) in Yankton, South Dakota. The congregation was located only 80 miles south and west of Canton, but due to the structure of the Synod, RPRC was located in another Classis. After a couple of months of phone calls and interviews, we traveled as a family to Yankton on a cold 
January weekend to preach and meet the congregation. In April of 1997, we moved to Yankton to begin again. The idea of pursing a degree in the counseling realm was also realized. In the fall of 1997 I began pursuing a Masters Degree in Marriage and Family Therapy at North American Baptist Seminary in Sioux Falls, SD. My primary interest at the time was to enhance my skills as a pastor and secretly, to try, and make certain that I would not replicate the mistakes of the past.

During the course of this study into family systems I not only learned about helping other people, but I also gained some tremendous insights into the working of my own family system. At this time my primary goal involved how to be a better pastor. I was not looking to move into a counseling profession. Due to that focus I paid little attention to the requirements for becoming a licensed Marriage and Family Therapist.

I graduated from that program in the Spring of 2000, with a second Master's Degree and with every intention to make that my final degree. During my study in this Master's program I became familiar with a topic I had previously only been exposed to by rumor and innuendo, and that was clergy sexual abuse. As part of a requirement to earn a better grade in a class I had written a paper and done a little research on the topic of clergy sexual abuse. While I had some information, it was little more than a "hobby" rather than a focus in my life. That is until in one week in conversations with three people whom I have still not met they all three suggested I had a passion for clergy health, in particular sexual abuse and should pursue some further study. I have a motto that works well in my life that states if one person calls you a donkey, ignore them, but if two people call you donkey buy a saddle! In this case, I had heard from three so I went in search of a saddle in the form of a doctoral program. I considered several Doctor of 
Ministry programs, and even a degree in Clinical Psychology. I finally settled on the Doctor of Ministry program at Western Theological Seminary, as this was the only program that would allow me to pursue my passion, and tailor a course of study to fit my needs.

I began this program in 2002, and it was not long until I learned that my passion was really fueled by something that Dr. Jaco Hamman called shame. As he talked about this topic I found myself figuratively scratching my head and saying that I did not even have the vocabulary to understand what he was describing to me. As the first learning unit of my Doctor of Ministry program I set out to learn as much as I could about the psychodynamics of shame. Secretly, I was hoping to prove Dr. Hamman was wrong, however I found how deeply shame was rooted in my very psyche and fabric. This understanding has allowed me to unwrap many of the unanswered questions in my life, as well as to understand some of the dynamics that cost me my position in Canton.

Today, I have been the pastor of the Riverview Park Reformed Church for nearly eight years, slightly longer than my tenure in Canton. The congregation seems to be growing and responding to the direction and leadership I am giving it, and Lord willing, we can remain together as pastor and congregation for several years to come. If that is going to happen I know that I need to remain in touch, not only with the congregation, but also with who I am and how I have been shaped for ministry. 


\section{Chapter Seven}

\section{Identifying Narratives of Harm and Lines of hope \\ In My Own History and Life}

Identifying narratives of harm in one's own life is not as easy as it might sound.

As I look back over my life the most traumatic experience in my life was a move from Southern California to Central California, not exactly the fodder for dysfunctional families. My parents were both present in my home during my formative years and the most trouble I had with the law was a ticket for reckless driving (I was 16 and enjoying life at the time). Thus, looking for narratives of harm will need to take a different form. The first challenge in the process is much like what a congregation or any organization has to attend to, and that is attempting to gain an objective understanding of one's life to begin with, and that in and of itself is a feat that not everyone is able to achieve and one that I am certain I have not fully mastered. What I do know is that this process was not born out of the comfort of my living room, nor was it a leisure time project. The work of self-reflection and understanding really did not begin in my life until 1996 when I was asked to resign as the pastor of Bethany Reformed Church, Canton. Normally that would be identified as a narrative of harm, and in some respects it is, but like many of these situations and circumstances that "firing" provided the impetus to begin a journey of self discovery that has taken some rather strange twists and turns. 


\section{Shame: A Hidden Narrative}

While there are other narratives that I discovered earlier in my journey, none holds the key to my behavior and attitudes, as does the concept of shame. Through most of my life I have had a vague sense that I was somehow just not quite good enough, that I was somehow flawed. My mother would tell me it was because my father could never pay me a compliment or tell me that I had done something good. To an extent she is correct, and if I chose to I could go through my life blaming Dad for his shortcomings. If I chose to do that, I would short circuit the whole process of learning that has been a part of my life these past seven years.

My introduction to shame came in the first year of this Doctor of Ministry process. At Western Theological Seminary part of the process is a revising of an autobiography. Since I had written up a history for some previous work I merely resubmitted that story. What was different this time is that while my group was discussing my life, Dr. Jaco Hamman suggested that he could see shame on every page of my autobiography. The more he talked, the less I understood what he was saying. So, the first learning unit in my program was to dig deeply into the psychodynamics of shame.

As I began to learn about the psychodynamics of shame, I realized that my introduction to shame began before I was even able to verbalize what I felt. But I felt it, and I felt it a level that I was not even able to acknowledge. I felt that shame in the unspoken feelings that somehow I was inferior or less than desirable, or in some way unwanted by the people around me. Having said that, I don't want to accuse my parents or other caregivers, as I know that was never told that in so many words. My mother is a 
loving, caring person, and my father, while far from perfect, would never have intentionally said anything so unkind. Having said that, I also know that I was born ten months after my sister, which meant my parents who had been married less than two years now had not only one surprise, but two. The first surprise was when my mother became pregnant with my sister before the wedding. The second surprise was my birth, so soon after my sister's. So my parents were in a new marriage, trying to sort out that relationship in the midst of extended family on both sides. Add to this, the pressure that they now had two infants and limited opportunities. My father, who at this time was still working on his GED, was working two jobs just to support his new family and unless I miss my guess, both felt overwhelmed and unprepared for what had happened to him. Like others in their situation, my parents were not only exposed to shame and made to feel shamed for their behavior, but they also came from families and religious traditions that majored in shame, which only contributed to their sense of shame.

What happened is that both of my parents were carrying a heavy sense of shame, and passed the shame on to my sisters and myself like any other family legacy. While that sounds like I am blaming my parents, that is not the reality, for as Heinz Kohut ${ }^{189}$ and theorists who follow his lead, remind me shame begins before we can even begin to verbalize what is taking place in our lives. Donald Capps, ${ }^{190}$ who takes his lead from Kohut, sees the seeds of shame being sown when infants are born to parents who under stimulate them during the early days and months of their lives. Parents do not set out of teach their children a way of living in the world in a dysfunctional way, the under stimulation comes from parents who were raised by parents who "were themselves cold,

\footnotetext{
${ }^{189}$ Kohut, Heinz, The Restoration of the Self, International Universities Press, Inc. Madison, CT. 1977.

${ }^{190}$ Capps, Donald, The Depleted Self, Sin In A Narcissistic Age. Fortress Press, Minneapolis, MN. 1993.
} 
aloof or even indifferent, lacking in empathy, and thus unable or unwilling to mirror the child's desire to be loved and to love in return." ${ }^{191}$ The reality that I had to come to grips with is that my parents were themselves, handicapped, as their own parents had been, and in all likelihood, this legacy of shame has roots that go back many generations. When I incorporate the insights of Murray Bowen ${ }^{192}$ and his understanding of family systems, we are all part of a five generation system moving through history. What we learned from our parents will be passed on to our children, to our grandchildren and on down the generations, unless someone stops to look at the legacy and decides to make a change.

That is exactly what I chose to do, or should I say, was compelled to do. While each author had some helpful insights into the complexity of shame it was the German theorist Heinz Kohut who helped me the most. Kohut talks about the needs of children to have parents who could adequately respond to their needs and mirror their wants and needs. The reality that I had to come to understand is that my parents were not emotionally able to do that, which left me with a deficit. What I also began to realize in reading Kohut is that in conversion, God becomes the ultimate empathic parent who accepts us unconditionally. When I accepted God's gift of grace and forgiveness, I also found the "ultimate" parent who would accept me regardless of my failures and support me in my ef forts. While I recall very well a conversion experience as a teenager, I was in my mid forties before I understood what grace was about.

In many ways I am a recovering "shame-aholic." I still find many of the triggers of shame operating in my life. I still work too hard and say "yes" to too many involvements in an effort to prove to people that I am a good person. I still wrestle with

\footnotetext{
${ }^{191}$ Ibid., 29.

${ }^{192}$ Kerr, Michael E. and Bowen, Murray; Family Evaluation An Approach Based on Bowen Theory; W.W. Norton and Co. New York, 1988.
} 
affirming my own children for who they are, instead of what they do. But, I am learning to compliment them for themselves and affirm their value as people, not just for what they can do. What I continue to see, is that for me, the greatest struggle in this realm is in the area of projecting blame on others.

I am also learning to accept a compliment. One of the problems I have faced in my ministry is when I received a sincere compliment, I found a way to downplay the compliment. Since following and completing this learning unit, I have found myself more comfortable with my skills and abilities, and less eager to down play the positive compliments that come my way.

\section{Loss In Ministry}

That may sound like a common problem for every pastor. Pastors are called to the bedside to attend to the dying and offer consolation to the living. That is part of what is included in the job description. But this loss proved to be much more personal than I fully appreciated at the time. For this loss did not involve a parishioner or even a family member, it was a fellow pastor. Dean Scott was at least ten years younger than I was. Full of energy and enthusiasm, Dean was going to save the world single handedly, if no one else joined him. Dean was one of my closest friends in ministry, even though he served the Assembly of God congregation in town and I was at the Reformed Church.

On a cold November evening in 1995 Dean and one of his elder's answered a call from a distraught wife whose husband was down at the river threatening to commit suicide. While Dean was trying to intervene the man jumped into the river saying he would drown himself. The elder with Dean volunteered to go for help, and told Dean to 
wait, as help would be along shortly. In the time between the elder's going for help and the return of the police officer, both Dean and the man who was threatening suicide were in the river. The man threatening suicide was pulled from the river shortly after the first rescuers arrived. We did not recover Dean's body until the next afternoon.

For me this was not just the death of a friend, but, myself, as a fireman and would be rescuer, this was also a line of service loss. For several years I carried a real anger toward Dean and his actions that night. Not only did I loose the better part of a good night's rest, but I felt an obligation to his family that he had left behind. That was a feeling I did not shake until nearly four years later while participating in a unit of Clinical Pastoral Education (CPE) and this topic came up. During that conversation and my usual "rant" about Dean and his failure to think beyond the next minute, it was pointed out that my anger was directed to myself. In Dean's loss of life I saw myself.

While that explains a little bit of my anger and frustration concerning his death, it was not until I look a long hard look at shame that I found a fuller answer to my reaction. One of the defenses for shame is that of projection. One of the insights I gained was that my father had chosen projection as his defense. He seemed never to be in the wrong, regardless of what happened around him, he seemed to blame someone else. I thought I had sidestepped that issue in my life and was better adjusted than my father. I now know better, I did not escape the family defense, I had not recognized what I was doing, it was so much a part of me.

I also recognize in myself signs of what has come to be known as Post Traumatic Stress Disorder. This has been identified in many fire service and rescue personnel following situations like this. Following Dean's death my love of fighting fires began to 
diminish, and since moving to Yankton, I have yet to re-engage in my avocation. My excuse has been that since I moved I have gone back to school instead of fire fighting. The truth is that since Dean died, I know that I am not invincible and that in my efforts to help others I too could loose my life, and that tempers my enthusiasm. Some might call it maturity, but I am not so sure.

\section{Its Time to Move Pastor}

Of all the situations I have encountered, I doubt that there is a more difficult one than being told that your services are no longer desired. Here again it was easy to begin with bombast and blame the foolish people who did not appreciate my brilliance. At that time I did not have a vocabulary to understand shame and the sense of failure that was being reinforced by the action of the elders at that time. All I knew is that I was hurt and angry and had very little recourse for resolving the hurt and frustration, other than leaving.

That announcement came nearly ten years ago and due to the work I have been doing and the effort to understand congregations and myself, I am feeling less a sense of shame and more a sense of peace about what took place while I was in Canton. As best I can tell, the situation in Canton was the result of conflicting visions for mission and ministry. I have always been a firm believer that the Church of Jesus Christ exists for those who are not yet their members. That holds firm for both the church universal, as well as the local expressions. In the Bethany Reformed Church a significant core group understood the pastor's job to be taking care of their needs. If I had been a little more attentive to some of those maintenance issues such as some visiting those who were 
already members, I probably could have continued for sometime. But I chose purposely to ignore that, attempting to delegate the calling to Elders who did not want to do that either. My failure was rooted in my inability to understand the needs of the congregation I chose mostly to continue my bull headed attitude regardless of the consequences. Looking back, I know the congregation had issues that in many ways had nothing to do with me. I have gained insight that indicates to me that as a congregation there were conflicts with leadership that predated me, but were played out in my life. I understand now that I was the fourth pastor to be asked to leave the congregation. But if it had not been for the work I have done in seeking advanced study in Marriage and Family Therapy, as well as the learning centered around shame, I would not be able to extend the same kind of grace to the congregation I once served.

Today, I am able to understand that God used that time to prepare me for the lessons he has been trying to teach me for some time. When I was asked to move on, I seriously considered resigning as a minister in the Reformed Church In America, or at least, taking a leave for a couple of years to pursue a degree in Marriage and Family Therapy at one of the regional universities. In the midst of that thinking, my Regional Executive suggested I submit my profile to the Riverview Park Reformed Church, which is the congregation I serve today. When I arrived in Yankton is that this congregation graciously allowed me to pursue both my role as their pastor and a second Master's Degree in Marriage and Family Therapy. As I like to tell people, I am not sure if the degree in Marriage and Family Therapy made me a good counselor or therapist, but I do know it has made me a better pastor. As Family Therapy is based in systems theory, the idea that every one interacts within a system, it has allowed me to understand that some 
of the dynamics and conflicts around me have nothing to do with me. When I begin to understand the principles of systems theory, I am able to work more effectively in nearly every situation I now find myself in.

\section{Finding Hope in Ministry}

Finding hope in ministry is always an interesting challenge. The hope and vision that have sustained me and kept me moving forward in ministry is found in my personal mission and vision statement which follows:

\section{Biblical Purpose}

My purpose is to glorify God and enjoy Him forever through:

* Maintaining a regular devotional life

* Serving others around me

* Equipping people for ministry and service

* Sharing the love of Christ with those who have never heard the good news of God's grace

\section{Ministry Values}

I value:

* Relationships, especially with Deb, Andrew and Erin

* Gift based ministry, helping people discover their niche in ministry

* Leading by example and encouraging others

* The changeless Gospel in a changing world

* The Bible as God's Word to us today and every day

* Close friendships

* Following where God leads

* The call to go and tell others of God's love

* Connecting life to the witness of Scripture

* Challenging the status quo

\section{Personal Calling Statement}

I have a Dream....

* Of leading a church that is making a difference in the lives of those who are members and who are changing the community in which it is placed, to bring the gospel of grace to the people of that community. 
* Of pastors with solid marriages that stand the test of time and the stresses of ministry.

* Of pastors who are leading churches that are changing their community that are changing the world in which they live.

* Of my family loving and supporting each other through all the challenges, difficulties, and joys of life.

* Of loving Deb for the rest of my life

* Of seeing Andrew and Erin serving Christ in their own way as they establish themselves in the world.

* Of networks of pastors who gather to support one another and encourage each other in ministry.

* Of churches all over the world working together as the body of Christ taking the gospel of Christ to those who have never heard.

What I have learned is that while that statement is an accurate and true representation of who I am and what I hope to achieve in my life, it also represents the reality of the shame that permeates my life. What I have discovered is the shame component of my personality is not necessarily a bad development. One intriguing component of shame is that altruism is a healthy defense against shame. As I make that statement I need to explain what I mean. In The Wisdom of the Ego, ${ }^{193}$ Valliant's basic premise is that we all have chosen defenses against shame. Some of these defenses result in the person being labeled as having psychological problems, while others do not:

Often what psychiatrists label as specific disease is no more than the patients coping with nonspecific dis-ease. Phobias, obsessions, even some psychoses are often more analogous to cough or fever than to diabetes or cancer. It is noteworthy however that the denials and self-deceptions that result from the deployment of what I call mature defenses result in no diagnosis. Not everyone who practices self-deception appears ill to others. The oyster, after all, deals with the irritation produced by a grain of sand by creating a pearl. ${ }^{194}$

When I look at my autobiography I know it contains many immature responses to shame, but I am also developing what Vailant would commend as healthy defenses.

\footnotetext{
${ }^{193}$ Vailant, George E., The Wisdom of the Ego; Harvard University Press; Cambridge, MA. 1993.

${ }^{194}$ Ibid; 34.
} 
A second defense that is employed often in my life is that of humor. Again both Vailant and Kaufman ${ }^{195}$ have noted that humor can also function as a defense, and fortunately, it also is considered to be a healthy defense. I also know that I have found myself using projection and blaming at other times to deal with and defend against those same feelings and emotions, and that is not at all healthy.

\section{Family}

Reading statistics about clergy families is seldom encouraging generally statistics reveal that most children raised in clergy homes see that as a negative experience instead of a positive one. Early on I realized that my profession allowed me a lot of flexible time to be with my family. As I was not able to be home every night, I arranged my time off during the week to correspond to the time my children had off from school. Before my children were in school, I took Friday to enjoy with the family. Once my son started school I shifted one day later and began taking Saturday as my day off. When my son was old enough to join Cub Scouts, I used my flexible schedule to be his Den Leader and eventually, his Scout Leader in Boy Scouts. This kind of flexibility has allowed me to be present when my children participated in sports or had special events at school.

While my children are part of my family, they only came into and are now leaving the family that Deb and I began 27 years ago. Deb has been a constant supporter, cheerleader, and critic as the situation called for. At times of frustration she has supported me; when I was over confident or moving in a wrong direction, she stood her ground to move me back. I know that I would not have survived ministry without her.

\footnotetext{
${ }^{195}$ Kaufman; ibid.
} 


\section{Being Part of a Bigger Plan}

When Jesus was ready to leave the earth he gave his disciples this last direction:

${ }^{18}$ Then Jesus came to them and said, "All authority in heaven and on earth has been given to me. ${ }^{19}$ Therefore go and make disciples of all nations, baptizing them in the name of the Father and of the Son and of the Holy Spirit, ${ }^{20}$ and teaching them to obey everything I have commanded you. And surely I am with you always, to the very end of the age." Matthew 28:18-20 (NIV) ${ }^{196}$

When I read that passage I find myself following a much larger plan than trying to lead a congregation in the Reformed Church In America. My calling is not just to grow a congregation or to lead a small group through a successful year of ministry. My role, my call is to be part of a mission that is spreading through the whole world! My calling, my ministry efforts and work has a worldwide impact. One pastor, when asked to say something about his business at the local Rotary Club, had this to say:

I'm with a global enterprise. We have branches in every country in the world. We have our representatives in nearly every parliament and boardrooms on earth. We're into motivation and behavior alteration. We run hospitals, feeding stations, crisis pregnancy centers, universities, publishing houses, and nursing homes. We care for our clients from birth to death. We are into life insurance and fire insurance. We perform spiritual heart transplants. Our original Organizer owns all the real estate on earth plus an assortment of galaxies and constellations. He knows everything and lives everywhere. Our product is free for the asking--but no one has enough money to buy it. Our CEO was born in a small, remote town, worked as a carpenter, didn't own a home, was misunderstood by his family, hated by enemies, walked on water, was condemned to death without a trial, and arose from the dead--I talk with him everyday. ${ }^{197}$

Realizing that the job I do will have an impact that is not only part of a global enterprise, but also stretches back to the beginning of time and has eternal consequences makes the role of pastor worth the challenges and encourages me to keep going.

\footnotetext{
${ }^{196}$ The Holy Bible : New International Version. 1996, c1984 (electronic ed.). Grand Rapids: Zondervan.

${ }^{197}$ Mason, Andy, Leadership Vol.20, \#2: 77.
} 


\section{Understanding Grace}

Of all the concepts and promises of God, grace is one that I have had a difficult time with and I believe the Church itself struggles with. It is my contention that if the Church of Jesus Christ ever understands how to extend grace to people we will not be able to build church buildings fast enough to accommodate the crowds. The challenge to me is how to do that in a world that is saturated by shame. When I finally understood that much of my behavior is motivated by shame in one way or another, I have been seeking to help others uncover that hidden shame and find the grace of God that can set them free.

Along this same line is an understanding of how God has shaped me for ministry and service. The longer I study, the more I am convinced that just as each congregation has a unique ministry in the world, so does every Christian. God has not sent us into the world to make clones of ourselves, he sent us to make disciples of Jesus Christ. God has called me to empower people to discover how their unique history and life story intersect with God's grace and what that means for them as they pursue not just careers and families, but living out their faith in the world. This is my ongoing task as well, and I usually phrase it in the form of a joke that: or one day I am going to decide what I want to be when I grow up! Behind that joke is a deep-seated desire to follow where God is leading me. I know I could not have scripted my life the way it has turned out, and if this is what following God in service is all about, I am looking forward to the years to come. The key to this understanding has been taking the time to reflect on my life, the good and the bad, and to understand that the grace of God is sufficient for all my failures and shortcomings. 


\section{Conclusion}

As I look back on my life I find a lot of victories to celebrate. There are not a lot of narratives of harm. I cannot find any signs of abuse, unless you consider chores abuse. I had a stable home life, an intact family, and a good education. I have also been accorded the opportunity over the course of the past eight years to reflect on this journey and this family that I grew up in. As part of the study for Marriage and Family Therapy was to study Murray Bowen and his approach to family systems, I had to construct a genogram of my family and then develop an analysis based on Bowen's approach to families. From that investigation and work I began to view my family from a completely different perspective and began to appreciate my father for the first time in my life. Then three years later, while working on the question of shame, I realized that the things I resented about my father were in many ways a function of his growing up in a shame based home, and unless I was careful, I would be passing the same traits to my own children.

For me this did not happen in a vacuum; and it began with a group of elders "inviting" me to look for another job. Once again Socrates was correct, the unexamined life is not worth living. It has only been since I began to think about what was causing me to do the things I was doing and what was driving me to try to do everything at once that I was able to step back and focus on what was most important in my life. As with every process, it is easy to slip back into old habits, and shaming and blaming others still comes too easily. It is a constant effort to keep focusing on grace and not shame. 
Another component necessary for pastors who take the time to understand their own unique shaping and call in ministry is a congregation that is willing to walk along side and with them through this process. During the past eight years the congregation here has donated weeks and hours of time to allow me the luxury of asking the question, what has God called me to do? I realize it has been packaged as working on a Master's Degree and a Doctor of Ministry program. At the heart of both of these has been my search to understand my unique shaping. I am also convinced that unless this partnership is realized and developed, both pastors and the congregations they serve will be short changed. This does not mean every pastor needs to go through the same process I did. Much of the same learning and maybe even more learning can be achieved through Clinical Pastoral Education programs and other programs of continuing education. The Refocusing material also provides opportunities for pastors to ask these questions and seek God's leading. In the end, unless the congregations these pastors are serving support those efforts, the end result will be a lot of self aware, unemployed pastors, and a lot of frustrated and confused congregations. If both pastor and congregation are or have been engaged in a process of reflection and seeking God's unique calling on their lives, then renewal is possible and probable. Renewal is never a one-way street; it will always require both leaders and congregations to be asking the same questions and working together to find the answers. 


\section{Chapter Eight}

\section{Summary and Conclusion}

When I began this process I was following my original Doctor of Ministry goal that reads as follows: "Empowering the congregation to identify and address the narratives of harm in a congregation and the community/society." My goal was to survey the congregation, look over the historical record, discover the narratives of harm that influenced the congregation, and understand how those events had influenced the situation that I found when I became the pastor of the Riverview Park Reformed Church. What unfolded was a much different story than I expected.

I did find lots of narratives of harm that were recorded in the history of the congregation and wove themselves around and within the history of the congregation. What were unexpected were the lines of hope that were operating right alongside the narratives of harm.

While I was prepared to discover the narratives of harm embedded in the story of the congregation, what I was not expecting to find was how narratives of harm and lines of hope were often intertwined. In many situations narratives of harm and narratives of hope seemed to change positions and like a diamond revealed different facets in different lights. When I look back over the story of the congregation, the first narrative of harm that surfaced in the life of congregation was the element of shame. This is probably due to my own study on the topic, but never the less, it was clear that shame had played a significant part in the life of the congregation. One of the continuing effects of shame in the life of this congregation is that shame tends to limit the choices and options for those who are shamed. For this congregation, moving forward has been an incremental process 
that was bound by the limitations of shame, and has not allowed the leadership to contemplate a full range of options, especially more practical ones that seemed less significant and grand. (I think you are implying this). This showed up in the desire to pursue a second congregation rather than develop a second worship service. The limitations also surfaced in the discussion of a building project. The congregation focused, on a new sanctuary instead of seeking a lower cost multiple use space as had been proposed earlier. The move toward worship space was driven by the fact that the previously proposed fellowship hall that would allow for sports as well, was dubbed a gymnasium by the pastor's critics.

Other narratives of harm showed up in the multiple prescriptions for change and renewal that never delivered what had been promised, instead only added to the sense that this congregation would never achieve its potential. The other narrative of harm that I want to highlight here was the dependence on the pastor to provide for the health of the congregation. This dependence on a top-down leadership has done as much harm as any other narrative in the life of this local church.

What I did not expect to find were the lines of hope. In revisions and reviews of this project it was suggested that I use the phrase "narratives of hope" to compliment narratives of harm. I chose to keep the phrase "lines of hope" for this reason. A line in geometry has no beginning and no end. It comes from the past and projects into the future. While a narrative is a story that is told about something that has happened, the narrative is past tense, the story resides in history. These narratives often have a continuing influence in the life of the person or the community, but essentially there is a historical element here. Lines of hope, on the other hand, indicate and signify an ongoing 
and continuing story of possibility and change. If a congregation or an individual will look to these lines and nurture these lines of hope, the future will be different than the past and will be a source of empowering for change.

As I looked at the life and history of the congregation, lines of hope emerged in surprising and often contradictory places. These lines appeared in a focus on youth and children's ministries. A line of hope surfaced in individuals who took the time to invest themselves in these youth and children. There is a line of hope even in the renewal processes that surfaced periodically as the congregation sought to move forward and looked at new models and processes for ministry and service in the community.

Another surprising discovery in this study is documented in the chapter that, for lack of a better term, I have called contraindications of harm and health. One way to explain these contraindications is Hegel's approach to reality. He understood that "the human mind invariably moves from thesis to antithesis to synthesis, employing each synthesis as the thesis for a new opposition to be transcended by yet a higher level, continuing in a perpetual waltz of intellectual achievement." ${ }^{198}$ In these situations the thesis found its antithesis which brought about a much different result than had been expected. A second way to understand these unexpected findings is found in what has been labeled the "law of unintended consequences."199 That law reminds me of is that what I intended by my actions is not always what will take place, and often something unintended will result in the place of what I had intended.

\footnotetext{
${ }^{198}$ Available online at: http://www.philosophypages.com/hy/5k.htm\#hege

${ }^{199} \mathrm{http}: / /$ www.econlib.org/library/Enc/UnintendedConsequences.html. The first and most complete analysis of the concept of unintended consequences was done in 1936 by the American sociologist Robert K. Merton.
} 
So a contraindication of health and harm at RPRC is the reality of the sucessful interim. There I found a top down leadership style co-existing with a strong lay leadership system. I also found that health did not begin to evolve until after incredible pain. I found that healing did not begin to take place until the congregation understood itself to be in significant and substantial trouble. It was not until a well-loved and long tenured pastor was asked to depart that the congregation found itself in a situation that allowed healing to take place. That story was really the conclusion of an earlier narrative of harm that also demonstrates the complexity of narratives of harm and lines of hope. As was noted in the analysis, when the congregation split, a narrative of harm was established. In that same narrative is a line of hope, for that split held the seeds of the eventual health of the congregation.

I also found this contraindication in the realm of goal setting and long range planning. Even the work done in the Refocusing process has been largely forgotten or laid aside and has not had the impact it could or should have. What is a line of hope can also become a narrative of harm, and the reverse can also apply in most situations.

Probably one of the most surprising discoveries of this study was the way this congregation has utilized its building. I placed this in the contraindications because in one light, the congregation can be seen as subcontracting ministry to outside groups. In the early history of the congregation a preschool was allowed to use the building to help provide financing. While the church has long sponsored a Boy Scout Troop, the Troop has been largely self-supporting and other ministries in place could be seen as a way for the congregation to do ministry without investment. In another light, this congregation has seen its facility as a place provided to them by God that allows them to empower 
others to do ministry. In the positive light, as a line of hope, the congregation has seen that this building is a shared facility, not just for themselves, but also for the larger community around them.

The major lesson that can be taken from this case study is that a congregation cannot move forward until they have taken the time to look back and understand the narratives of harm that have caused pain and suffering for the congregation. The congregation must also identify the lines of hope to identify the ways and places God has been at work in their life and how this speaks to their future. It is in the intersection of pain and celebration that God seems to be at work shaping and creating his people who are called by his name.

This case study also supports the finding that there are many different processes to lead church renewal and revitalization. While it becomes clear that I am most familiar with the Refocus process, the second Interim pastor used a different process. As a matter of fact in conversation with him, he really did not have a formal process at all. Obviously, there are multiple ways to bring about church renewal/revitalization. While not explicitly stated in this study, I am familiar with two other processes that could be used, if not three or more that are being marketed or used by church consultants in assessing and developing church health.

What is supported is that the "would be" church helper needs to keep in mind the complexity of the congregation before him/her and not become fixated on a particular process or program. The key learning in this study is that the process was more important than the program. I would add that the helper is also a key ingredient in this process. When it comes to church renewal there are many ways to achieve the desired 
result and the key ingredients are not necessarily present in every congregation or community.

The study also points out that renewal and health is not static. The interim pastor moved the congregation forward, and much like a family therapist solved some issues, but not every one. His major achievement was to unify the congregation around a vision/mission statement. That allowed the congregation to state with precision what they hoped to find in a clergy person. The vision statement alone did not solve all the problems. Nor did the Refocusing process that I lead. Both moved the congregation forward.

As I speak of health, a footnote needs to be added here. While this study has been moving forward a task force has been at work on a building proposal. Once again the congregation is confronted with a building project. This time I observe some anxiety about building and a desire not to offend. On the other hand there is a willingness to engage the congregation and to push the agenda of reaching out the community without the overtones of a vote on the tenure of the pastor (myself this time) entering the picture.

A second development in this building project has been a subtle change in focus. When I began I was told not to even consider a second worship service. As was noted in the text I was encouraged to begin the exploration of a second congregation but not a second worship experience in the same congregation. As the building project moves forward and the price of the "worship space" increases, the "value" of a single worship experience steadily declines, and the pursuit of a second congregation declines in importance. At this writing the desire to have two different worship experiences in the same congregation is moving forward. 
This case study was not just the story of a particular congregation in a particular place this is also my story. As I noted in the chapter dedicated to the analysis of my life's journey, I found myself in much the same situation as the congregation I serve. I was content to keep trying and doing the same things and the same approaches to ministry that I had always employed until the time came when I was hurting. It was only after I was asked to leave the congregation and the community I enjoyed that I was ready to do some serious introspection.

What I found on my journey were issues of shame that are still being worked out and resolved. I found hope in writing first a personal statement of how I do ministry and then in writing a personal mission and vision statement that includes a Biblical purpose. I found that God has called me and empowered me in ministry, and I am doing what I am supposed to be doing in my life; this is my purpose for being.

One of the lessons I retained from the classroom while being taught to be a therapist is that most people will not change until what they have been doing is causing pain. As long as congregations and pastors are able to function relatively pain free, there will be no changes even possible. The problem with this approach is that often when the pain is felt, much as in medical situations or in counseling situations, there is little time to make the necessary changes. Fortunately for the church in this case study and for me, the pain came at a time that allowed us both to make the changes necessary to continue to remain viable in our areas.

Even as I follow that law of unintended consequences into my life and ministry, I find my journey to be filled with the effects of this situation. Pursuing a degree in the counseling field as a route from full time clergy status has actually strengthened and 
supported my commitment to the professional clergy status. My interest in seeking clergy health for the "pastors" around me has lead me to become a much healthier pastor.

For me, taking the time to examine my life, to understand how life experiences have shaped me, and to discover the psychodynamics of shame, has allowed me to function differently as a pastor. Equally important to me has been the development of collegiality through my various studies and involvement in various processes. One of the realities in my professional experience is the lack of RCA colleagues in close proximity to my ministry locations. Through the work I have done in both the Marriage and Family Therapy study and even more so through this Doctor of Ministry has been the cultivation of RCA colleagues. Now the challenge to me is to engage and continue to cultivate those colleagues.

While I hate to admit it, at least in print, part of my distance has been my own doing and my own effort. The same man who encouraged me to write my first vision statement had been a life long missionary. He said to me once that since I had grown up in California, I would always be doing ministry cross culturally in the Mid-West. I am still attempting to unpack just what that means in ministry. I know today that is truer than I understood at that time. My challenge from this learning will be to develop systems and processes that allow me to connect more intentionally with RCA colleagues to develop and cultivate that sense of collegiality in other ways.

Moving away from my personal journey, there is another highlight that needs to be mentioned in this summary, and that is the importance of both pastors and congregations to have mission and vision statements. I can recall being asked in interview processes what my vision for the particular church would be. My honest 
answer has always been that I did not have one as I had no idea, as I had never been to that location before.

On the other hand during my first contact with RPRC. The RPRC search committee gave me a copy of the church profile (a document used by the RCA to give basic information about a congregation) and also a copy of their mission and vision statement, along with the instructions that if I did not agree with that vision they would keep looking. I had also been encouraged to write a personal vision statement that emphasized my own perspective on ministry. Upon receipt of the congregation's vision statement, I sent my own with similar instructions to the ones I had receieved.

The learning from this experience is the necessity of having both pastors and churches articulate their mission and vision. This allows both pastors and congregations more easily to find a successful match. This concept was born out in a learning unit in my Doctor of Ministry program. I surveyed three congregations and their pastors asking the question: "What has made this a successful match?" I found that both congregations and pastors who had a clear idea of their gifts and skills for ministry, as well as what they both wanted in terms of that ministry, were successful.

Both clergy and congregation need to work to understand their context and their strengths in ministry. This process does not work as well if either the congregation or the pastor has failed to do this work. Both pastor and congregation also need to avoid the temptation of writing a vision statement to attract a particular style of ministry that is not reflective of who they are. Bottom line honesty and integrity, along with a commitment to seeking where God is at work in the life of a congregation, is essential. 
There is still the issue of introspection. What becomes clear from this study is that both the congregation and the pastor need to take the time to understand their own personal history as an essential part of the renewal process. For PRRC both the narratives of harm and lines of hope allowed it to look back and realize that God had been trying to build a church at that location for over 35 years.

The final observation that I want to make is that church health is incredibly fragile. I believe supporting clergy and developing healthy clergy is in many ways a rather simple process. As the Refocusing process points out, personal renewal precedes the corporate renewal. Keep in mind is that both are dynamic not static events.

As RPRC was moved toward health by the Interim Pastor and walked further along that path through the Refocus process, the leadership of the church has been diligent in nurturing that process; even to the point of purposely scheduling bi-monthly Consistory meetings. Those bi-monthly Consistory meetings alternated with Ministry team meetings. While that experiment has been discontinued, the emphasis on pushing decision making to the lowest level has not. Even today Ministry teams are empowered to make decisions, while Consistory is charged with overall direction and supervision of ministry.

While the congregation is healthy at the moment, health is not easily maintained. Much like shedding weight, if the dieter is not careful, the weight loss is quickly replaced by gain. There is a similar process in congregational health. Unless succeeding generations of leaders in the congregation are helped to achieve and maintain health, the congregation will revert back to old patterns and habits quickly. 
What is true for congregations is also true for its pastors. I have made some major steps toward health and have learned about the issues and questions that impact my life and ministry. I also know there is much more that remains to be done. The major themes of my life will need to be revisited, and the learning of the past several years will need to be reinforced and supported. In every way I have just begun a journey or selfunderstanding that will require a lifetime to complete.

Part of what drives me to continue this journey is the finding of Robert Clinton ${ }^{200}$ that few leaders finish well. The Refocusing material defines finishing well this way:

Finishing well could be defined as a life that until its end is increasingly 1) more in love with Christ, 2) more committed to his service and 3) for devoted to godly leadership. ${ }^{201}$

According to Walling one of the components to finishing well is maintaining a learning posture through life. ${ }^{202}$ That is my commitment and part of the learning in this process is how to keep learning in all of life and to seek the mentors I need to keep on learning each and every day of my life.

\section{Concluding Post Script}

One final issue that needs to be taken into account in the life and history of both the congregation and the pastor, and that is neither exists in isolation. The Reformed Church in America is a connected denomination. A book of order governs the denomination. There are judicatories and structures that tie the local church to the larger body. The reality is that the congregation did not arrive here by itself, there were other

\footnotetext{
${ }^{200}$ Clinton, Robert J.; The Making of a Leader, Recognizing the Lessons and Stages of Leadership Development; Navpress; Colorado Springs, CO; 1988.

${ }^{201}$ Walling, Terry; Focusing Leaders; p. 1.6.

${ }^{202}$ Ibid.; p. 1.5.
} 
larger forces at play in different times. It also implies that what took place here could represent a microcosm for denomination.

The implication is this, the lines of hope and narratives of harm that are seen in this local congregation, are in some ways the story of the denomination. While not a prescription of changes that must be made, nor a description of what is wrong, what follows are questions that arise from this study.

One of the issues alluded to in the project is the broader system of the denomination that is present. While any critique or evaluation of that larger body is outside the scope of this project, I would like to briefly mention some topics that might be considered by those who would like to broaden the topic of renewal and church revitalization to a larger body or group of congregations.

a One of the issues that plagued Riverview Park Reformed Church for many years was the top down leadership style of the pastors and the executives around them. Is that continuing today? If so, how will it affect a denomination that is attempting to bring about wide spread renewal?

a It was not until the second Interim pastor assembled a large group of people to focus on the life and health of the congregation that health began to develop. In the Refocusing process, the principle of change demands a substantial number of people involved to be successful. In the denomination are there enough people involved in working for renewal, or is this agenda "owned" by only a few? What is the pay off for the local congregations who are being asked to change? Finally, whose problem is this? The local congregation or the denomination? 
- One of the axioms of system theory is homeostasis. The best illustration of this is the ever-present thermostat. The role of the thermostat is to make certain the room is neither too hot nor too cold. If the room is too warm, it calls for the air conditioning; too cool, it calls for the furnace. In organizations, if one person begins to call for change that is seen as too radical, they get too hot, there are systems that function to "cool" them down and stymie any radical change. On the other side if there is not enough change, or the person is not doing enough, therefore, getting too cool, there are systems in place to encourage them to return to the community standard. Given this tendency of systems, what is being done to counteract or overcome this tendency?

a Currently a lot of time and energy is being devoted to the objectives of the Lily Grant $^{203}$ that seeks to foster and develop healthy pastors. Is this enough, or even the right approach to clergy health? Will it truly achieve the goals set forth? Or will it develop into a narrative of harm for the churches and pastors of the RCA?

- What are the lines of hope in the RCA? For a denomination to have survived over 400 years, what are the stories of hope and celebration? Where is the denomination growing? What innovative approaches to ministry are being explored?

a Finally, what are the resources and tools for renewal that are available to local congregations and pastors? Do the pastors and congregations of the denomination understand the necessity of change? Or is this renewal focus seen only as someone else's problem? Even more directly, is the message of renewal and revitalization even being heard at the local church level?

\footnotetext{
${ }^{203}$ A Revitalized Leadership for a Renewed Church A Grant Proposal to Sustain Pastoral Excellence Submitted by the Reformed Church in America, page 2. Available online at http://www.rca.org/images/lead/ministry/lillygrant.rtf.
} 


\section{Bibliography}

The Acts and Proceedings of the $197^{\text {th }}$ Regular Session of the General Synod, Reformed Church In America; Available on line at: http://www.rca.org/synod/minutes/2003/index.html

The Acts and Proceedings of the $198^{\text {th }}$ Regular Session of the General Synod, Reformed Church In America; Available on line at: http://www.rca.org/synod/minutes/2004/index.html

Ahlstrom, Sydney E.; A Religious History of the American People; Yale University Press, New Haven, CT; 1972.

Blackaby, Henry T. and King, Claude V.; Experiencing God, Knowing and Doing the Will of God; LifeWay Press, Nashville, TN; 1990

The Book of Church Order, Including the Government, The Disciplinary and Judicial Procedures, the Bylaws and Special Rules of Order of the General Synod, the Formularies, The Reformed Church In America, 2004 Edition; 2004 Reformed Church Press, New York, NY. 2004

Bugbee, Bruce; Cousins, Don; Hybels, Bill; Network: The Right People...In the Right Places for the Right Reasons. Zondervan Publishing House, Grand Rapids, MI; 1994

Borden, Paul D., Hit the Bullseye, How Denominations Can Aim the Congregation At the Mission Field; Abingdon Press, Nashville, TN. 2003

Capps, Donald, The Depleted Self, Sin In A Narcissistic Age. Fortress Press, Minneapolis, MN. 1993

Cozad Neuger, Christie, "Narratives of Harm: Setting the Developmental Context For Intimate Violence"; In Her Own Time: Women and Developmental Issues in Pastoral Care, Jeanne Stevenson Moessner, ed.; Fortress Press, Minneapolis, MN 2000

Dethmers, David; Revive Us Again. Help for Stagnant, Stuck and Sterile Churches; Reformed Church Press, New York, NY. 1994

Hauerwas, Stanley and Willimon, William H; Resident Aliens; Abingon Press, Nashville, TN; 1989

Kaufman, Gershen, Shame the Power of Caring; Schenkman Books, Inc; Rochester, Vermont. 1985 
Kerr, Michael E. and Bowen, Murray; Family Evaluation An Approach Based on Bowen Theory; W.W. Norton and Co. New York, 1988

Kinnison, Randall, "Practical Spirituality: Leading a Church toward Spiritual Maturity" January Term Class at North American Baptist Seminary, January 2005

Kohut, Heinz, The Restoration of the Self, International Universities Press, Inc. Madison, CT. 1977

Kotter, John; Leading Change; Harvard Business School Press, Boston, MA. 1996

Max Health; Phase 3 of the Refocusing Process. Information available online at http://www.churchsmart.com/store/viewItem.asp?idProduct=1035

Miller, Alice; The Drama of the Gifted Child, The Search for The True Self, Basic Books, New York, NY; 1997

Minutes of Consistory of the Riverview Park Reformed Church, along with files and other records. Located in the church Offices located in Yankton, South Dakota.

Newbigin, Leslie; Foolishness to the Greeks. The Gospel and Western Culture; Eerdmans Publishing Co; Grand Rapids, MI. 1986.

Nichols, Michael P. and Schwartz, Richard C; Family Therapy, Concepts and Methods. Allyn and Bacon, Boston, MA. 1995

"Our Call" available on line at: http://www.rca.org/ourcall/index.html

Refocusing Network. Available on line: http://www.refocusing.org/resource.html

Reformed Church In America Vision Statement. Available one line at: http://www.rca.org/aboutus/mission.html

A Revitalized Leadership for a Renewed ChurchA Grant Proposal to Sustain Pastoral Excellence Submitted by the Reformed Church in America, page 2. Available online at http://www.rca.org/images/lead/ministry/lillygrant.rtf

Robinson, Phil Alden; Field of Dreams; Universal Studios;1989

Roxburgh, Alan and Regele, Mike; Crossing the Bridge, Church Leadership in a Time of Change; Percept Group, Inc. 2000

Schwartz, Christian A. and Schalk, Christoph; Implementation Guide to Natural Church Development; ChurchSmart Resources, Carol Stream, IL; 1998 
Schwartz, Christian A. and Schalk, Christoph; Natural Church Development Survey; available from ChurchSmart Resources

Vailant, George E., The Wisdom of the Ego; Harvard University Press; Cambridge, MA. 1993

Veldhuizen, Rodney; "Shame and Enduring Legacy of Pain"; Unpublished learning Unit in partial fulfillment of Doctor of Ministry Degree at Western Theological Seminary, Holland, Michigan; 2003

Veldhuizen, Rodney; "Becoming the Church in a Postmodern Culture"; Unpublished learning Unit in partial fulfillment of Doctor of Ministry Degree at Western Theological Seminary, Holland, Michigan; 2004

Walling, Terry B., Focusing Leaders, Phase one of the Refocusing Network System; ChurchSmart Resources, Carol Stream, IL; 1998 


\section{Appendix \#1 Definition of Terms}

Church: In this paper, the church will be used to refer to the ideal image that is seen in the Gospels and pictured by Jesus. The term "church" will be used to refer to what is commonly known as the universal church rather than a local congregation or denomination.

Classis: The classis is an assembly and judicatory consisting of all the enrolled ministers of that body and the elder delegates who represent all the churches within its bounds. (The Book of Church Order, page 29.)

Congregation: The local expression of the Church. According to The Book of Church Order of the Reformed Church In America, a congregation is a body of baptized Christians meeting regularly in a particular place of worship. A local church is a congregation properly organized and it is served and governed by a regularly constituted consistory.(The Book of Church Order, page 11.)

Consistory: A consistory is the governing body of a local church. Its members are the installed minister/s of that church serving under a call, and the elders and deacons currently installed in office. A consistory is a permanent, continuing body which functions between stated sessions through committees. (The Book of Church Order, page 11.)

Deacons: The office of the deacon is one of servanthood and service representing Christ through the action of the Holy Spirit. In the local church deacons are chosen members of spiritual commitment, exemplary life, compassionate spirit, and sound judgment, who are set apart for a ministry of mercy, service, and outreach. They are to receive the contributions of the congregation and to distribute them under the direction of the consistory. The deacons give particular attention and care to the whole benevolence program of the church. They have charge of all gifts contributed for the benefit of the poor and distribute them with discretion. They visit and comfort those in material need and perform such other duties as the consistory may assign them. (The Book of Church Order, page 13.)

Denomination: A term in Protestant ecclesiology that references the various divisions and doctrinal Distinctives within Protestantism.

Elders: The office of the elder is one of servanthood and service representing Christ through the action of the Holy Spirit... Elders, together with the installed minister/s serving under a call, are to have supervision of the church entrusted to them. They are set apart for a ministry of watchful and responsible care for all matters relating to the welfare and good order of the church. They are to study God's Word, to oversee the household of faith, to encourage spiritual growth, to maintain loving discipline, and to provide for the proclamation of the gospel and 
the celebration of the sacraments. They have oversight over the conduct of the members of the congregation and seek to bring that conduct into conformity with the Word of God, thereby empowering all members to live out their Christian vocation in the world. Elders exercise an oversight over the conduct of one another, and of the deacons, and of the minister/s. They make certain that what is preached and taught by the minister/s is in accord with the Holy Scripture. They assist the minister/s with their good counsel and in the task of visitation. (The Book of Church Order, page 12.)

General Synod: The General Synod is the highest assembly and judicatory of the Reformed Church in America. It is composed of representatives from each Classis, as well as delegates from the regional synods. This body meets annually, but functions between stated sessions through the General Synod Council, commissions and agencies. (The Book of Church Order, page 63.)

Government and Structure of the Reformed Church In America: The four basic or focal governmental units in the Reformed Church in America are the consistory, the classis, the regional synod, and the General Synod. The consistory is divided further into a board of elders and a board of deacons. The board of elders, the classis, the regional synod, and the General Synod exercise judicial as well as legislative powers. A governmental unit exercising its judicial powers is called a judicatory, and at all other times the governmental unit is known as an assembly. (The Book of Church Order, page 1) [If more information is desired on the structure and government of the Reformed Church in America this information is available on line at: http://www.rca.org/leaders/bco/index.html.

Reformed Church In America: The particular denomination in which I serve and am ordained. More information about the Reformed Church In America can be found at: http://www.rca.org/index.html.

Regional Synod: The regional synod is an assembly and judicatory consisting of ministers and elders delegated by each of the classes within the bounds determined for it by the General Synod. (The Book of Church Order, page 59) 


\section{Appendix \#2 \\ Interview Questions}

Interview Questions

(Those Who Left)

1) How long were you members of Riverview Park Reformed Church? Approximate dates?

2) What are your memories of the pastors who served Riverview Park Reformed Church: Rev. \#2

Rev. \#3

Rev. \#4

3) What changes or developments did you see or notice taking place at Riverview Park Reformed Church that were either positive or negative during the times when these men served the church?

4) What were the reasons you chose to leave Riverview Park Reformed Church? 
5) Where did you go following leaving Riverview Park Reformed Church?

a) Another established congregation? Which one?

b) Worked for new congregation?

c) No church affiliation.

6) What were the factors that influenced your choice of a church home?

7) What is your level of satisfaction with your current church home?

1-being totally dissatisfied

10-Totally satisfied

8) Is there anything else you would like to tell me about your experience with church in general or Riverview Park Reformed Church in particular? 
Interview Questions

(Those Who Left/Returned)

1) How long were you members of Riverview Park Reformed Church? Approximate dates?

2) What are your memories of the pastors who served Riverview Park Reformed Church:

Rev. \#2

Rev. \#3

Rev. \#4

3) What changes or developments did you see or notice taking place at Riverview Park Reformed Church that were either positive or negative during the times when these men served the church?

4) What were the reasons you chose to leave Riverview Park Reformed Church? 
5) Where did you go following leaving Riverview Park Reformed Church?

a) Another established congregation? Which one?

b) Worked for new congregation?

c) No church affiliation.

6) What were the factors that influenced your choice of a church home?

7) What were the influences/circumstances that allowed you to return to Riverview Park Reformed Church?

8) On a scale of $1-10$, with 1 being sick and ready to die and 10 being totally healthy, what would you say is the level of health of Riverview Park Reformed Church today? Compared to the late 80's and early 90's? 
Interview Questions

(Those Who Remained)

1) How long have you been a member of Riverview Park Reformed Church? Approximate dates?

2) What are your memories of the pastors who served Riverview Park Reformed Church: Rev. \#2

Rev. \#3

Rev. \#4

3) What changes or developments did you see or notice taking place at Riverview Park Reformed Church that were either positive or negative during the times when these men served the church?

4) What were the reasons you choose to remain at Riverview Park Reformed Church? 
5) What was your experience of Riverview Park Reformed Church following the departure of a portion of the congregation?

6) What was the morale level of those who remained following the split?

7) Did you notice any changes in the behavior/attitude of Pastor \#4 during or following this time?

8) When Pastor \#4 left in 1994, what were your impressions of the church's health?

9) When Rev. was hired as an "interim" pastor, what did that mean to you about the future of the church?

10) Did you participate in the activities and meetings Rev. congregation move forward? initiated to help the

11) If yes: What were your impressions of his efforts and work in the congregation? 
If no: Why did you choose not to participate?

12) How long did those meetings last and what was the outcome of those efforts?

13) Do you see any lasting impact from Rev. work in Riverview Park Reformed Church?

14) Would you see Rev. ministry as a positive or negative time for Riverview Park Reformed Church?

15) Did you participate in the Refocusing Process lead by Rev. Veldhuizen?

16) Can you compare the work of Rev. and the Refocusing process?

17) On a scale of 1-10 (1-being totally sick and 10-Couldn't be healthier) what would you say is the health of Riverview Park Reformed Church today?

18) Is there anything else you would like to tell me about your experience with the church in general or Riverview Park Reformed Church in particular? 


\section{Appendix \#3}

\section{RIVERVIEW PARK REFORMED CHURCH \\ CHURCH ATTITUDES QUESTIONAIRE}

How the church feels about itself and its ministry is a significant factor in the church's growth and development. You can help by filling out this questionnaire and returning it to the church the next two Sundays. Please take note of both sides of the sheet. THANK YOU!

AGE :

$15-25$

$26-35$

$36-$

45

$45-55$

$56-65$

$65 \&$

over

1. What do you consider to be the greatest strengths of our

church? (rank from 1 to 3, with 1 being the highest)

The loyalty of our members

The lay leadership

The openness to change

The image in the community

The strength and vitality of our programs

The location of our building

The potential for growth

The pastoral leadership

The building and facilities

2. What do you consider to be the greatest weakness of our

church? (rank from 1 to 3, with 1 being the highest)

The loyalty of our members

The lay leadership

The openness to change

The image in the community

The strength and vitality of our programs

The location of our building

The potential for growth

The pastoral leadership

The building and facilities

3. What do you think about the Christian Education ministry of our church?

Not meeting needs

Barely passing

Above average

Meeting needs

very effective

4. I find the worship services at my church...

Dull, Unjinteresting

Routine 
Some good, some bad

Usually helpful

Consistently inspiring

5. What do you think about the Evangelisin Outreach of our church? Not meeting needs

Barely passing

Above average

Meeiing needs

Very effective

6. How often do you invite people to come to our church?

Never

Seldom

Occasionally

Erequently

7. Which of the following do you think should receive more emphasis in the church?

Bible Study / Christian Education
Evangelism
Youth Program
Missions - local and world
Social involvement and concern
Spiritual growth of our people
Other

8. All in all, do you feel. you belong and are part of the church family?

Generally, no

At times

Usually

Accepted and a real part

9. How often do you financially support the church?

Seldom or never

Irregular - several times a year

Irregular - fairly often

Regularly -* a planned amount (per week,

month)

Regularly - a tithe (10\%) of my income

10. In verbally sharing my faith with others I'm a total failure

I attempt it once or twice a year

I sometimes try, but meet with limited

success

share my faith

I look for and enjoy opportunities to

11. If given the opportunity to participate in training for outreach ministry, I would...

Run the other way

Be cautiously interested

Be available if asked

Sign Up 
12. In using my spiritual gifts in the work of Christ and my church, I...

Don't know or care what my gifts are Would like to find out more about my

$\begin{array}{ll}\text { gifts } & \text { Would like to use my gifts if asked } \\ \text { Have identified and am using my gifts }\end{array}$

13. Please share any other thoughts or concerns you may have about our church: 


\section{Appendix \#4}

\section{VISION STATEMENT}

Riverview Park Reformed Church strives to be a bonded group of believers, spreading the Word of our Lord, end showing the love of Jesus Christ to others.

We intend to do this during the next five years by focusing our time, energy, financial resources, and talent on the following goals:

\section{Goal I}

We intend to offer dynamic Christian Education to all segments of our congregation.

We will achieve this goal by up-grading the nursery in terms of staffing, equipment, and furniture and offering child--care for worship, Sunday School, and all church events; by renovating various Sunday School rooms in order to create additional Sunday School space and make the rooms more attractive and functional; by regularly offering a second, topical adult education class designed especially for parents of children in Sunday School; by purchasing a portable keyboard for music; and by support and training for Sunday School teachers.

\section{Goal II}

We intend to reach out especially to young families, single parents, and the elderly in the next 5 years in our community.

We will achieve this by offering promotional events, need-meeting ministries, and invitational events which meets the needs of these 3 groups; by renovating our facilities to make them visually attractive to visitors; by offering excellent Christian Education; by developing an excellent visitor follow-up system; and by maintaining a top-notch nursery, etc. Our goal is to average 175 in worship by the year 2000

\section{Goal III}

We intend to renovate our church facilities to make them visually appealing and to meet existing needs of our ministries.

We will achieve this goal by renovating Sunday School rooms in a variety of ways this fall; by "sprucing up" the parsonage; by replacing the church roof, by repaving the parking lot and north entryway; by replacing carpeting, lighting, and front doors in the church foyer and hallway; by improving the lightin9 and sound system in the sanctuary and making it more visually appealing to visitors; by renovating both bathrooms and creating a handicapped, unisex bathroom where the janitors closet is now; by creating two "kitchens in one" to make the existing kitchen more efficient; by replacing the front sidewalk, and by improving lighting of sidewalk and parking lot, etc. 


\section{Goal IV}

We intend to build a dynamic, close-knit, involved, and invested congregation.

We will achieve this by decentralizing such responsibility and authority out of Consistory and creating new ministry teams/committees, such as a music committee; by offering large group fellowship events and small group offerings such as hone Bible studies, focus groups, new member orientation groups, youth groups, etc.; by recruiting and training new leaders; by improving church-wide communication; by helping members discover their spiritual gifts, etc.

\section{Goal V}

We intend to provide an excellent Pastoral/Congregational care system!

We will achieve this by training care-givers to provide excellent care for different groups of people, such as nursing home patients; by developing a phone ministry and a card ministry; by intentionally connecting new members into small groups or ministry teams; and by calling a new permanent, dynamic pastor.

Five years from now RPRC will have a renovated and attractive church building, grounds, and parsonage. RPRC will have a number of groups, classes, ministry teams for all ages and interests. RPRC will be an exciting, loving congregation which is a magnet drawing in people who need Jesus Christ. RPRC will, 5 years from now, offer a variety of educational events such as "How to Manage Your Money", Christian parenting classes, beginning Bible study groups, etc. RPRC will, 5 years from now, have a highly involved congregation ministering to each other and reaching out to people in need. RPRC will, 5 years from now, be a bonded congregation that spreads the Word of our Lord and shows the love of Jesus Christ to others. HALLELUJAH !

To Be Reviewed at Each Annual Congregational Meeting.

Approved unanimously in secret ballot at a Congregational Meeting held September 16, 1995. 


\section{Appendix \#5}

\section{Strategic Ministry Plan 2000}

\section{INTRODUCTION}

During the Spring of 1997, Rev. Stan Vandersal, the Synod the Heartland Executive asked our congregation if we would like to be part of a pilot program that was being introduced in the Reformed Church in America. This program, known as Refocus was something totally new to each one of us. While it sounded like something that was already in place or on going, given the history of this congregation, and the assistance that has been provided by both the Synod and the Classis, Pastor Rod encouraged the Consistory to explore the possibility of being a part of this pilot program.

Refocus turned out to be much more than a program, it is a process that has extended the development and work that was already in place at Riverview Park Reformed Church. What began as an exploratory effort to repay the Synod of the Heartland for all that they had done for the congregation, turned out to be an extremely beneficial time in the life and ministry of this congregation.

Where other programs offer their model to be placed into the context of the local Church, Refocus and the Natural Church Development model challenged and encouraged us to ask the question where has God been at work in the life of our church? Where is God calling us to go in the future? Then, given God's leading and direction, how are we going to get to where God has called us? Natural church growth is not based on any human strategy, but rather it is a process that helps to identify the essential elements of church health and using that to create an environment in which a church can grow naturally. As this environment develops in the church, God increasingly uses it to grow His church. Our task is to provide the kind of environment where growth is possible. When we do that, God will grow his Church.

This Strategic Ministry plan is not the final word here at Riverview Park

Reformed Church. It is to date, our best understanding of what God would have us to do. If you look carefully over our previous 5 year plan, you will find many things remain undone there, as at the end of this plan, there are likely to be things left undone. Yet looking back over the past 7 years, God has been at work in the life of the people who worship and service Christ at RPRC, and God continues to do mighty things in our midst as we are faithful to him and his calling.

\section{EIGHT ESSENTIAL ELEMENTS}

The Natural Church Development Project identified eight elements that are common to churches that were growing both spiritually and quantitatively. These are:

1. Empowering Leadership

2. Gift Oriented Ministry

3. Passionate Spirituality

4. Functional Structures (Organization that allows ministry to happen easily) 
5. Inspiring Worship

6. Holistic Small Groups

7. Need Oriented Evangelism

8. Loving Relationships 


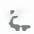

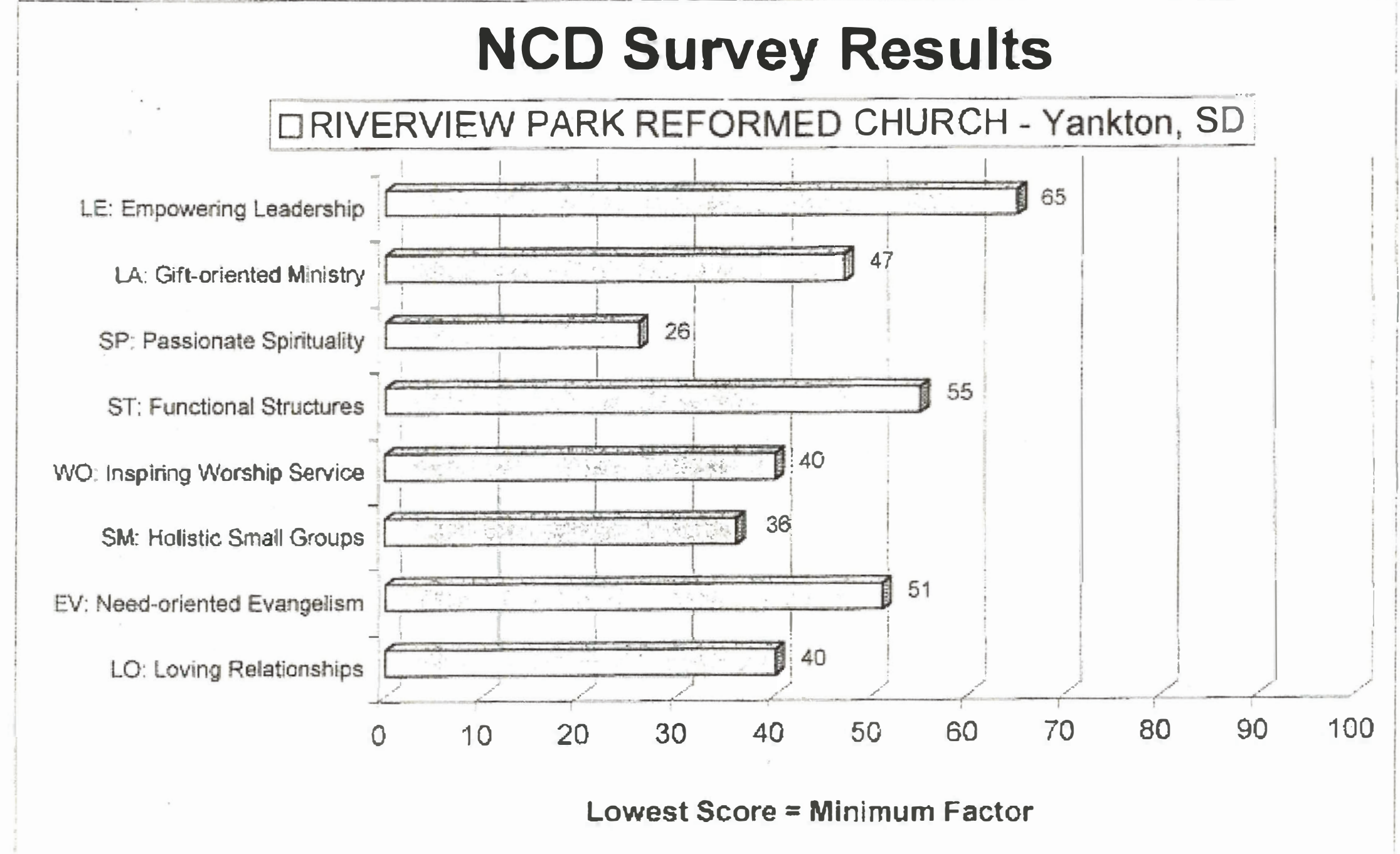




\section{8 \\ BIBLICAL PURPOSE}

A "biblical purpose" statement for a church is a "concisely worded statement" that answers the question, Why do we exist as a church?" This statements lays the foundation for our vision and ministry. We came to the following vision statement:

"Riverview Park Reformed Church strives to be a bonded group of believers, spreading the Word of our Lord, and showing the Love of Jesus Christ to others by: offering dynamic Christian Education; reaching out to our community; renovating our facilities; building an involved closeknit congregation; and providing excellent congregational care.

\section{MINISTRY MILESTONES}

In our first Summit in February, we created a church "timeline" (or Journey Wall, as we titled it). A timeline is a way of looking back to our birth in 1962 and putting together a picture of how God has worked in our history to shape us into the people we are today. The reason for doing so was to help us understand how God has worked in our past as an indicator of how He is working now and will continue to do so in the future.

We determined that our timeline could be divided into five "chapters" We entitled these chapters as follows:

1962-1965 Beginnings

1970-1975 Foundations

1980- 1985 Growth/Expansion

1990

Floundering

1995-1 999 Reassess/New Growth 
RPRC'S Journey Wall

Perseverance Church

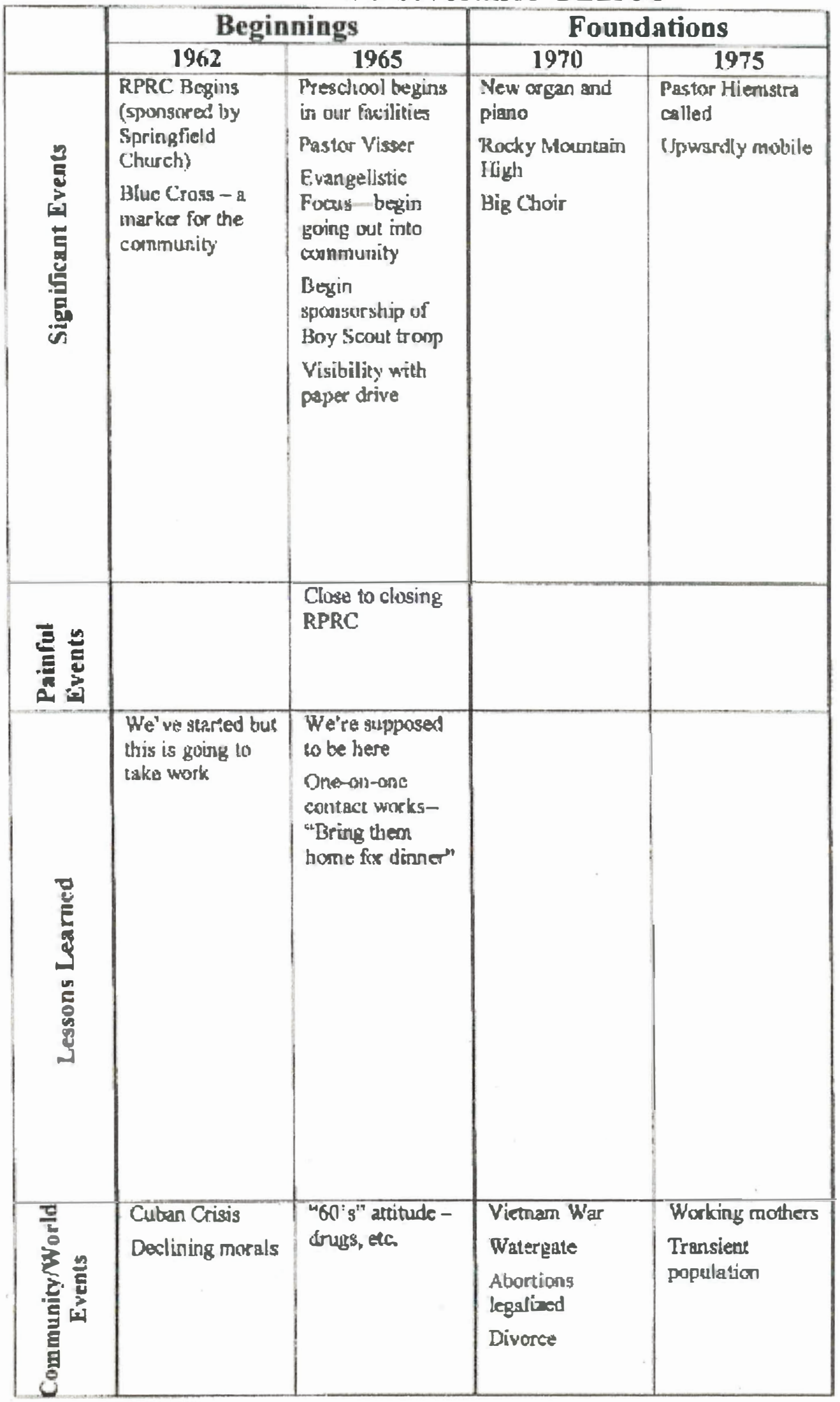




\begin{tabular}{|c|c|c|c|c|c|}
\hline & \multicolumn{2}{|c|}{ Growth/Expansion } & \multirow{2}{*}{$\frac{\text { Floundering }}{1990}$} & \multicolumn{2}{|c|}{ Rearsess/New Growth } \\
\hline & 1980 & 1985 & & 1995 & 1999 \\
\hline 总 & $\begin{array}{l}\text { AlMers proggram } \\
\text { Children's } \\
\text { thusicals'plin's } \\
\text { Adyenture Club } \\
\text { Children's choir } \\
\text { Church spirit }\end{array}$ & Two senitices & $\begin{array}{l}\text { Major conflict } \\
\text { Building propusal } \\
30^{\prime \prime \prime} \text { Anniversary } \\
\text { New menteers } \\
\text { class } \\
\text { Pastor Hiemsntat } \\
\text { leaves }\end{array}$ & 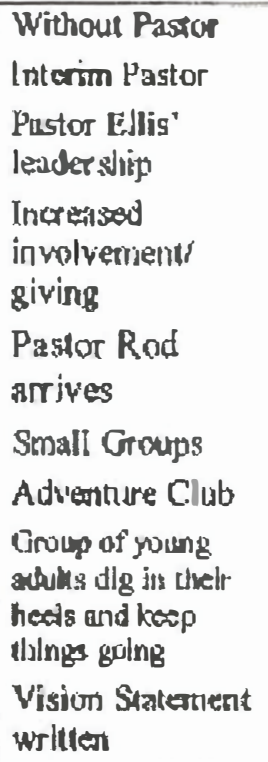 & $\begin{array}{l}\text { Networking } \\
\text { Band } \\
\text { MOPS } \\
\text { Grands anld } \\
\text { berilding } \\
\text { maintenance } \\
\text { New Youth } \\
\text { proerasn } \\
\text { Great chonr } \\
\text { Consecration } \\
\text { Sunday }\end{array}$ \\
\hline 氖 & & $\begin{array}{l}\text { Congegentional } \\
\text { Annual Meeting } \\
\text { where division! } \\
\text { canc to a Juead }\end{array}$ & & $\begin{array}{l}\text { No Calechism } \\
\text { (Wednesday } \\
\text { night prongans) } \\
\text { No youth group } \\
\text { RCWM decine }\end{array}$ & $\begin{array}{l}\text { Blue cross cisinte } \\
\text { down } \\
\text { Chureh thoir } \\
\text { (25 to t) mbrs) }\end{array}$ \\
\hline 总 & $\begin{array}{l}\text { Growing pains } \\
\text { accompany } \\
\text { growth und } \\
\text { exparrsion }\end{array}$ & $\begin{array}{l}\text { Nurture new } \\
\text { menibers to lead } \\
\text { lo it wol ventent }\end{array}$ & 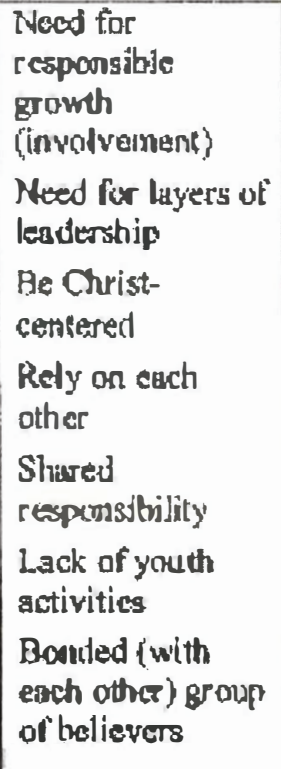 & & 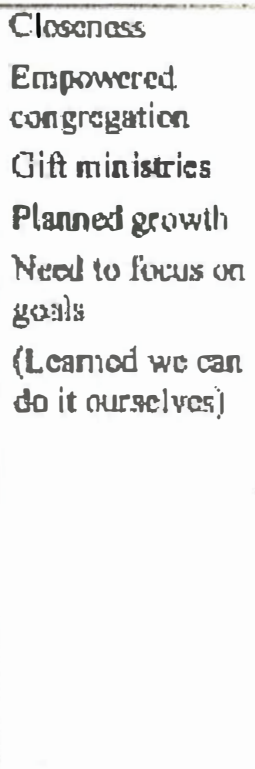 \\
\hline 氪 & $\begin{array}{l}\text { Revilalizations of } \\
\text { the Lake Area }\end{array}$ & $\begin{array}{l}\text { Enyploymenf } \\
\text { opporturity } \\
\text { Local econcmy } \\
\text { Sports } \\
\text { insolvemant } \\
\text { City Grouth }\end{array}$ & $\begin{array}{l}\text { Persian Gialf Wia } \\
\text { Fall of } \\
\text { communism } \\
\text { Lack of morality } \\
\text { (politics) }\end{array}$ & 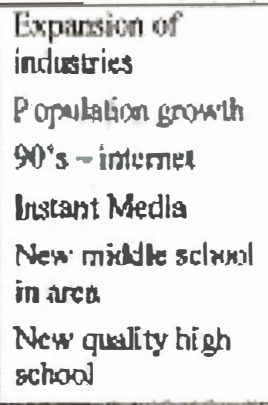 & $\begin{array}{l}\text { I.undsarom } \\
\text { Cruside }\end{array}$ \\
\hline
\end{tabular}


RPRC Refocusing Leadership Summit \#1

February 6,2000

Actual Values (in random order)

Sustaining/maintaining us

Youth

Music

Preaching/Worship

Cheapskates

Friendly (?)

Family/Fellowship (family of believers)

Loyalty/Faith

Pride/Ego

What does God value? (in random order)

Love and obedience

Salvation

Faithful workers

Humility

Stewardship

Worship/P raise

Family

Prayer

Truth

Faith

Trust

Forgiveness

Teach hope in resurrection

Fellowship with Christians

Children

Life/Human Life

Examples

Outreach 


\section{OUR MINISTRY FOCUS}

The following pages include the demographics of the area within a 10-Mile radius of Yankton and our "Ministry Focus" groups.

The demographics page shows the estimated 1999 households' Primary Concerns, Church Program Preferences, and Church Worship Style and Architectural Preferences

The "Ministry Focus" groups are what we determined are groups we need to focus on and reach in our community and what would be required to keep these people in our facility.

\section{CORE VALUES}

Core values are those values that we hold that come out of who we are They are the essence of a church's identity. They help us guide the church by answering the question, "Who has God shaped us to be?" For a church to be effective, they need to identify their core values and then faithfully adhere to them. A church may be willing to change certain programs and activities within the church but their values remain the constant that make their church unique.

There are two types of values: Foundational Values and Ministry Values. Foundation Values describe those beliefs and assumptions that best describe who we desire to be. Ministry Values are those assumptions and beliefs that describe how we choose to minister. The values are also on the following pages 
Riverview Park Reformed Church

Yankton, SD 57078

Demographics of Area Within 10-Mile Radius

\section{Indicator}

Primary Concern Indicator New

Estimated 1999 Households likely to be primarily concerned with:

important:

The Basics:

Maintaining Personal Health

Day-to-Day Financial Worries

Finding/Providing Health Insurance

Family Problems:

Dealing with Teen/Child Problems

Dealing with Alcohol/Drug Abuse

Finding/Providing Aging Parent Care

Community Problems:

Finding/Providing Good Schools

Neighborhood Crime and Safety

Dealing with Problems in Schools

\section{Church Program Preference}

Estimated 1999 Households if looking for a

Church likely to express as most

Spiritual Development:

44.0\% Bible Study Discussion \& Prayer Groups

$43.8 \%$

$33.1 \%$

$32.0 \%$

$23.9 \%$

$19.8 \%$

$13.4 \%$

$22.1 \%$

$20.8 \%$

$13.1 \%$

Adult Theological Discussion Groups $21.1 \%$

Spiritual Retreats

$11.9 \%$

Personal Development:

Marriage Enrichment Opportunities 16.4\%

Parent Training Programs $\quad 08.1 \%$

Community/Social Services:

Personal or Family Counseling $\quad 23.0 \%$

Care for the Terminally III $\quad 14.5 \%$

Food and Clothing Resources

$12.8 \%$

Recreation.

$33.7 \%$

Family Activities and Outings $\quad 29.3 \%$

Youth Social Programs

Active Retirement Programs $\quad 27.8 \%$

Spiritual/Personal:

Dealing with Stress $\quad 31.1 \%$

Finding a Good Church $\quad 17.9 \%$

Finding Companionship $\quad 15.3 \%$

\section{Style Indicator}

prefer

Estimated 1999 Households likely to prefer

Church Worship which is:

Emotionally Uplifting

Intellectually Challenging

Both of above

No Preference or Not Interested

Traditional/Formal/Ceremonial

Contemporary/Informal

Both of above

No Preference or Not Interested

Estimated 1999 Households likely to prefer

$09.8 \%$

$40.6 \%$

$21.3 \%$

$20.1 \%$

$26.7 \%$

$28.6 \%$
Estimated 1999 Households likely to

28.3\% Traditional

$27.1 \%$

Contemporary

$15.7 \%$

Both of above

$34.3 \%$

No Preference or Not Interested $\quad 22.8 \%$

Somber/Serious $\quad 08.9 \%$

Light and Airy $\quad 36.8 \%$

Both of above $\quad 28.1 \%$

No Preference or Not Interested 26.1\%

Estimated 1999 Households likely to prefer 
Traditional

Church Music which is:

Contemporary

Both of above

No Preference or Not Interested $9,4 \%$

Performed by Others

Participatory

Both of above

No Preference or Not Interested
$23.2 \%$

$21.2 \%$

$32.5 \%$

$23.0 \%$

$18.3 \%$

$25.1 \%$

$33.7 \%$

$22.9 \%$
Church Involvement and Mission Emphasis Focused on:

Community

Personal Spiritual Development

Both of above

$23.1 \%$

$13.9 \%$

3

$23.4 \%$

No Preference or Not Interested

Global Mission

$06.2 \%$

Local Mission

$35.0 \%$

Both of above

$32.1 \%$

No Preference or Not Interested 
RPRC. Refocusing Leadership Summit \#2

March 5,2000

Reasons the Last Twenty Attenders who have visited and continued at PRPC Stayed:

(in random order)

Young

Involved

Already Christian

Previous Commitment

Outgoing

Reasons the Last Twenty Attenders who have left RPRC Did Not Stay:

(in random order)

Transient

Job Change

Conflict

Ministry Focus Group 1 (MF-1) -- Our current mission focus

(Those we are most likely to reach-reflects the majority of our church family)

(in random order)

Young

Already Christian

Involved

Outgoing

Previous Commitment

What will be required to keep people in Ministry Focus Group 1:

Better Facilities

Nursery

Education Space, etc

Visibility

Advertising
Activities

Follow-up with Visitors

Neighborhood Network

Ministry Focus Group 2 (MF-2) - Potential of ministry in near future

(Those within our community who are similar to us and require additional ministries to attract and incorporate into our church family)

(in random order)

Younger and OIder

Non-Churched 
What will be required to keep people in Ministry Focus Group 2:

Same as MF-1

Latch-key/Day Care

Transportation

Financial/Marital/Kids

Community Focused Activities

Ministry Focus Group 3 (MF-3) - Needs further prayer and discussion

(Those who are distinctly different from our church family and require new approaches

and

ministries to attract and incorporate into our church family)

(in random order)

Different Ethnic Groups

Native American

What will be required to keep people in Ministry Focus Group 3:

Same as MF-2

Exposure

Attitude

Style of Worship

Another Language

Time of Worship

Mentoring Program

\section{Foundational Values}

(Values that reflect who we are. They are constant, with little or no change over time):

(in rank order)

I. Christ-centered

2. Relational/Loving

3. Unified

4. Joyful

\section{Ministry Values}

(Values that reflect how we will minister. They are dynamic, and sometimes change with the passage of time)

(in rank order\}

1. The "Word"-based

2. Harvest Focused

3. People Focused

4. Relevant.

5a. Organized 5b. Equipping/Empowering

6. Sacrificial Service/Stewardly

7. Creative 


\section{Picturing the Future}

(Vision: a PICTURE of a future reality from God's perspective) :

(Please see newsprint drawings)

[While not included in this report, every picture drawn at this time envisioned expanded facility and ministry.]

If God were to have His way, what would RPRC look like 3-5 years from today?

(in random order)

Expansion

Sunday School

Programming

Facilities

Christ-centered

Christ-based education

Outreach 
A VISION STATEMENT...

is a statement of faith that reflects the future direction of a local church

- helps to focus a congregation and provide a sense of direction

- is a word-picture of a future reality that reflects God's desire for a specific local church

- identifies where the church is going and how it will live out its biblical purpose within a specific location or context

\section{RPRC Vision Statement (Revised)}

Riverview Park Reformed Church strives to be a bonded group of believers, spreading the Word of our Lord, and showing the hove of Jesus Christ to others.

We intend to do this during the next five years by focusing our time, energy, financial resources, and talent on the following goals:

\section{GOAL I}

We intend to offer dynamic Christian education to all segments of our congregation.

We will achieve this goal by upgrading the nursery in terms of staffing, equipment, and furniture and offering child-care for worship, Sunday School, and all church events; by renovating various Sunday School rooms in order to create additional Sunday School space and make the rooms more attractive and functional; by regularly offering a second, topical adult education class designed especially for parents of children in Sunday School; by purchasing a portable keyboard for music; and by support and training for Sunday School teachers.

GOAL II

We intend to reach out especially to young families, single parents, and the elderly in the next 5 years in our community.

We will achieve this by offering promotional events, need-meeting ministries, and invitational events which meets the needs of these 3 groups; by renovating our facilities to make them visually attractive to visitors; by offering excellent Christian Education; by developing an excellent visitor follow-up system; and by maintaining a top-notch nursery, etc.

GOAL III

We intend to update our church facilities to make them visually appealing and to meet existing needs of our ministries.

We will achieve this goal by renovating Sunday School rooms in a variety of ways; by creating two "kitchens in one" to make the existing kitchen more efficient; by replacing the front sidewalk, and by improving lighting of sidewalk and parking lot, etc. 
We intend to build a dynamic, close-knit, involved, and invested congregation.

We will achieve this by decentralizing much responsibility and authority out of Consistory and creating new ministry teams/committees, such as a music committee; by offering large group fellowship events and small group offerings, such as home Bible studies, focus groups, new member orientation groups, youth groups, etc; by recruiting and training new leaders; by improving church-wide communication; by helping members discover their spiritual gifts, etc.

\section{GOAL V}

We intend to provide an excellent Pastoral/Congregational care system.

We will achieve this by training care-givers to provide excellent care for different groups of people, such as nursing home patients; by developing a phone ministry and a card ministry; by intentionally connecting new members into small groups or ministry teams.

Five years from now RPRC will have a renovated and attractive church building, grounds, and parsonage. RPRC will have a number of groups, classes, ministry teams or all ages and interests. RPRC will be an exciting, loving congregation which is a magnet drawing in people who need Jesus Christ. RPRC will offer a variety of educational events such as 'How to Manage Your Money", Christian parenting classes, beginning Bible Study groups, etc. RPRC will have a highly involved congregation ministering to each other and reaching out to people in need. RPRC will be a bonded congregation that spreads the Word of our Lord and shows the love of Jesus Christ to others. Hallelujah!

To be reviewed at each annual Congregational Meeting.

Approved unanimously in secret ballot at a Congregational Meeting held September 16,1995.

\section{MINISTRY MODEL}

Ministry models do three things:

--They reflect how a church will accomplish purpose and vision

--It is a conceptual diagram of how people flow through the life of the church

--It is a big-picture overview of the ministries of the church 


\section{Riverview Park Reformed Church Ministry Model}

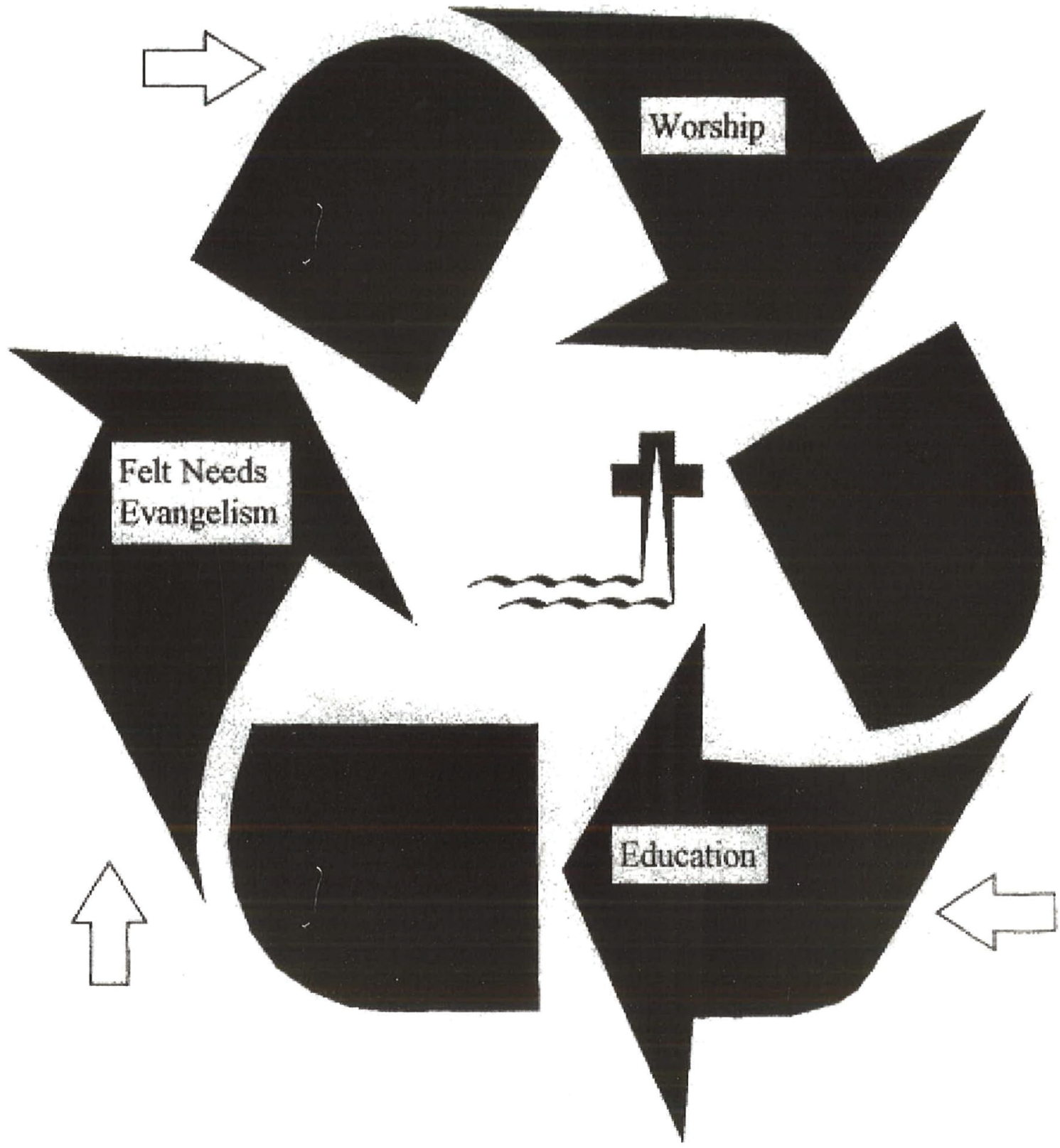

At RPRC there is no favored approseh ar entry point for new people into the clureds community. People conme into the churcis through worship, felt needs evangelisun efforts and through our Snall Groups, and Educational Ministries. The large arrows represent these three emphasizes all boing equal, while the smaller arrows represent the entry points for people conuing into contact with the community at Riverview Park Retormed Church 


\section{MINISTRY GOALS}

We started by putting together a list of possible goals that came from our focus groups.

The end result of the entire "Refocusing Process" is a 3-5 year Strategic Ministry plan. This plan contains our 3-year goals. The carrying out of this ministry plan will be done through the existing church structure.

The realization of these goals will be impossible without the involvement of many people who have both already been involved and those who would like to be involved in the more effective reaching of our community with the gospel of Christ. 


\section{3-Year Plan: Riverview Park Reformed Church}

Goal

Year 1

Year 2

Year 3

Develop Evangelism:

1) Post Service Greeters

a) Trial August 2000

b) Elders Greet Worshippers Following Worship

$\mathrm{X}$

X $\quad X \quad X$

2) Friendship Pad Review And Welcome Visitors Team

a) Recruit Team to Formulate Visitation Plan

$\mathrm{X}$

b) Team and Evangelism Ministry Team

Develop Church ministry Flier

c) Visitation Teams Contact Visitors

3) Assist/Encourage Mothers of Pre-Schoolers and Scouts

a) Continue to Provide space for and support groups

b) Provide a parents night out as needed for MOPS

c) Celebrate Scout Sunday with Scouts in Attendance

$\mathrm{X}$

$\mathrm{X}$

X

$\mathrm{X}$

$\mathrm{X}$

cate Youth In Mission and Outreach

a) Encourag/ Develop Youth Group Mission Trips and community service

b) Youth Mission Trip, 2001

X

$\mathrm{X}$

$\mathrm{X}$

5) Internet Website to Highlight Ministry Researce/ Development

$\mathrm{X}$

\section{Passionate Spirituality}

1) Tithe Budget for Missions Giving

2) Congregational Leaders Participate in Experiencing God Fall of 2000

3) Fall 2001 Begin Offering Experiencing God

4) Regularly Schedule Network Classes to Assist members Identify Spiritual Gifts

$\begin{array}{ccc}X & X & X \\ X & X & X \\ X & X & X\end{array}$

Youth Families and Singles Ministry

1) Church Fellowship Ministry Team Plans

5th Sunday Fellowship Event with Youth inviting MOPS and Scout Families

2) Youth Group Staff

Hire Part Time Youth Director

Spring 2001

Spring 2001
$\mathrm{X}$

X

X

X 


\section{Year $1 \quad$ Year 2 Year 3}

\section{Pastoral Care and Outreach Coordinator}

1) Write Job Description for Pastoral Care Outreach

Coordinator to include

a) What is available in community

b) Where is it available.

c) Coordinate Community Needs

Develop roster of people with specific

gifts \& talents to provide community service

d) Assisting Pastor in Elderly/Shut In Calling

e) Counseling (?)

2) Hire Part Time Pastoral Care Outreach Coordinator

Develop Adult Education

1) Continue to offer and Teach Adult Sunday School

$\mathrm{X}$ $\mathrm{X}$

2) Spring of 2001 WEGAR will begin offering Class on Sunday Evenings using Focused Living Workbooks $\mathrm{X}$ $\mathrm{X}$

\section{Implement WEGAR In Ministry Teams}

1) Summer 2000, begin WEGAR Meetings

a) Consistory providing initial leadership

b) Ministry Teams elect own leadership

$\mathrm{X}$

$\mathrm{X}$

2) Ministry Teams Meet 4 Times Annually To implement program and ministry at RPRC.
$\mathrm{X}$

$\mathrm{X}$ 


\section{Appendix \#6}

\section{Comparison Between the Work of the Interim Pastor and the Refocusing Process as Developed by Terry Walling and Church Resource Ministries}

\section{The Interim Pastor's Process}

1) Focused on Installed Leadership

2) Utilized a study format to gain insight and understanding of issues and problems.

3) Sought information through home visits and interviews.

4) Focused on three questions:
a) Where have you been?
b) Where are you going?
c) How are you going to get there?

5) Primary focus was on past pathology and helping to provide healing.

6) Developed Mission and Vision Statement with small group of leaders.

7) Sought input and information after vision was developed.

8) Utilized small groups to revise plan and vision prior to vote.

9) After congregation had understood vision and plan, asked for approval of vision by secret ballot.

10) Gained unanimous approval of new vision statement.

\section{The Refocusing Process}

1) Begins with small leadership team to guide process.

2) Works with a larger core of leadership people, usually 30-45.

3) Most information comes from group that assembles for leadership summits.

4) Focused on Three Questions:

a) Where have you been?

b) Where are you going?

c) How are you going to get there?

5) Focus is on understanding the past and moving toward a healthier future.

6) Information after summits is shared with congregation through smaller groups after summit meeting.

7) Mission and Vision statement worked on by smaller group, presented to leaders for input and direction.

8) Vision presented and revised by small groups discussion process.

9) After congregation understands mission and vision plan, plan adopted and followed by leadership.

10) Approval of revised mission and vision statement approved unanimously by full congregation. 
Appendix \#7

What Follows are the Charts that

Describe the Four Rs of Refocusing 


\section{The Four Rs of Revitalization}

\section{Revitalizing Local Churches}

Local church revitallzation is complex and dlverse. Churches are ar different stages in their development, requiring different types of resourcing. By assessing the health of a local chusch, leaders discover the approprlate level required for their setting. Denominations can use the four $R s$ as the basis for building regional renewal strategies.

The Four Rs of Church Revitalization: Resourcing - Refocusing - Restoring - Rebirthing

\section{Example Church No. 1 (Resourcing)}

Conslder the results of the Natural Church Develagrment Survey bar graph of one chudd. Notice that there are five scores in the $65+$ range. All durches benefit from envisioning efforts, but this church would not need an entire stratagic planning process. This church should seek to secure an outside consultant to bring specific resourcing and training in the minimum tactor element (i.,e, need-oriented evangelism).

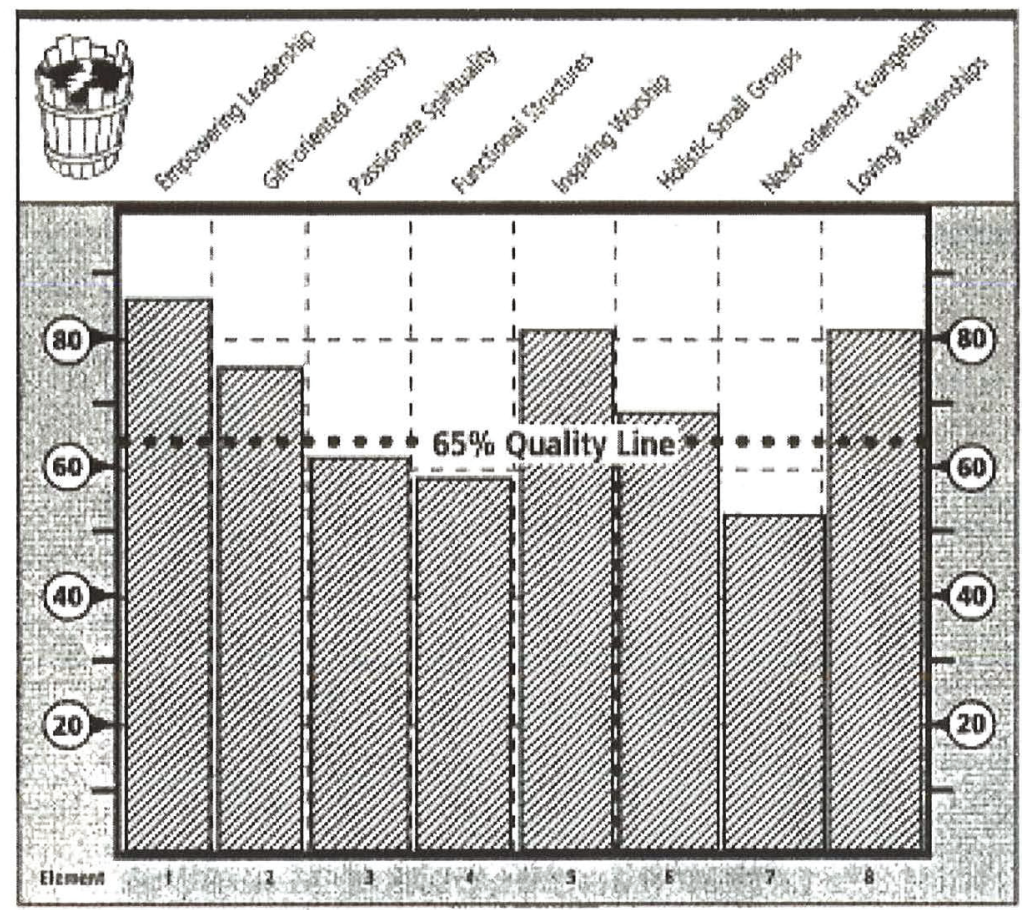

\section{Reflection Questions}

- Do these scores accur ately reffect our ministry as we know it?

- How car wa benefit from the help of an outside rescurcing spectalist?

- Is there someone we know that could provide corrsultation and coaching? Who? 


\section{Example Church No. 2 (Refocusing)}

Consider the Nafural Church Development Survey results from the second church. Notice that most of the scones fall below $65 \%$ and three scores are near $30 \%$. This church represents a church that is a candidate for refocusing and is a typical representation of a plateaued church. A church with scores between $30 \%$ and $65 \%$ would benefit from an strategic planning process like Refocussing Your Cherech. In the Church Networks, leaders are empowered to direct a strategic planning process. The envisioning exercise produces a five-year plan for ministing and greater focus on the autward harvest.

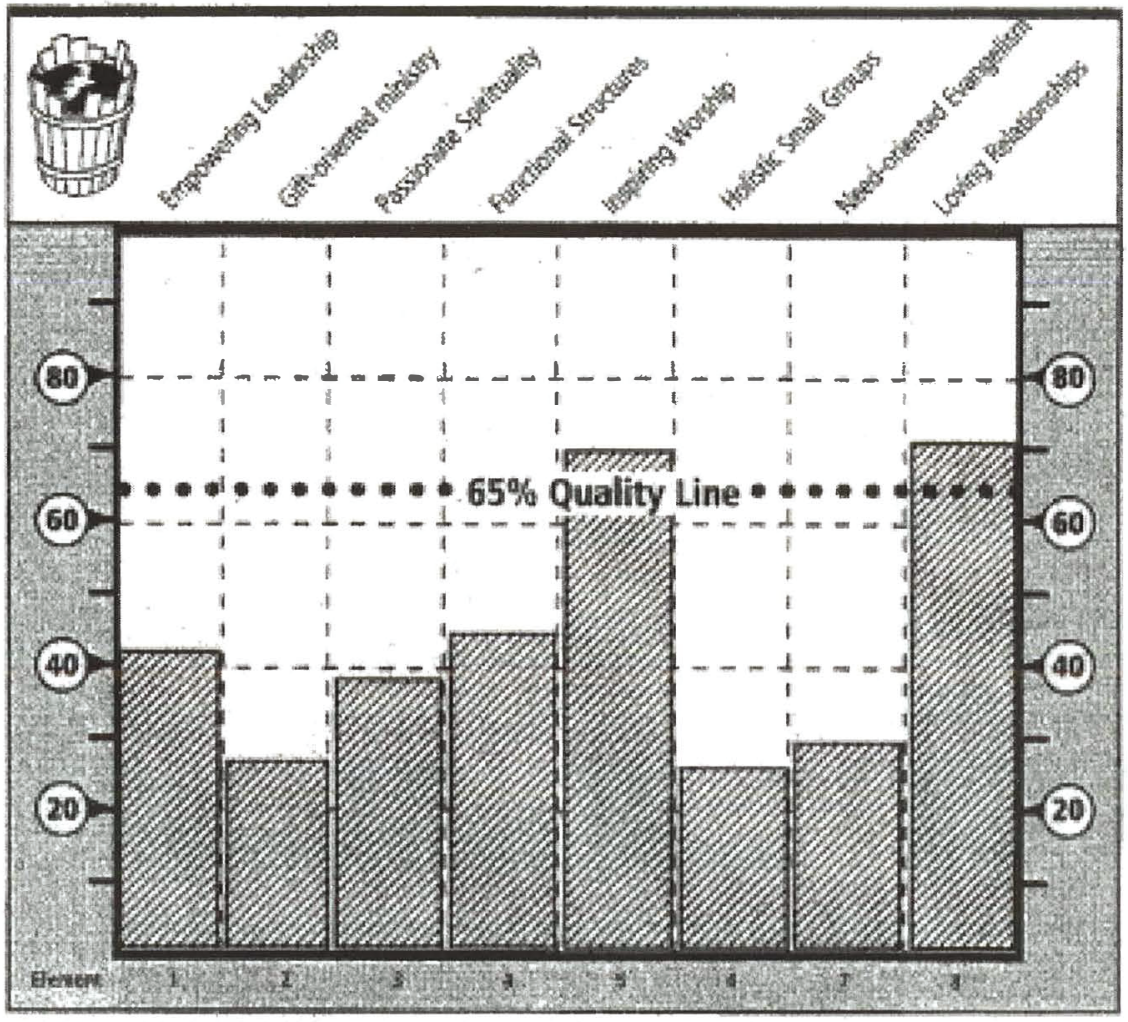

\section{Reflection Questions}

- Do these scores accurately refiect aur ministry as we know it?

- Haw can we benefil from the help of an envisioning process?

- How can prepare our people for strategic planning?

- Who in the cturnctis should' be cansulted? 


\section{Example Church No. 3 (Restoring)}

Consider the results from the third church. Notice that most scores fall on or below 30\%. Scares falling below 30\% indicate a weakness that could requlre an intentional intervention process, often involving outside assessment and more intensive help. In churches without a senior pastor, an intentional imterim pastor can be effective in leading the congregation through a period of reconciliation and spiritual renewal. A church like this would typically require additional help beyond what a strategic planning process could provide.

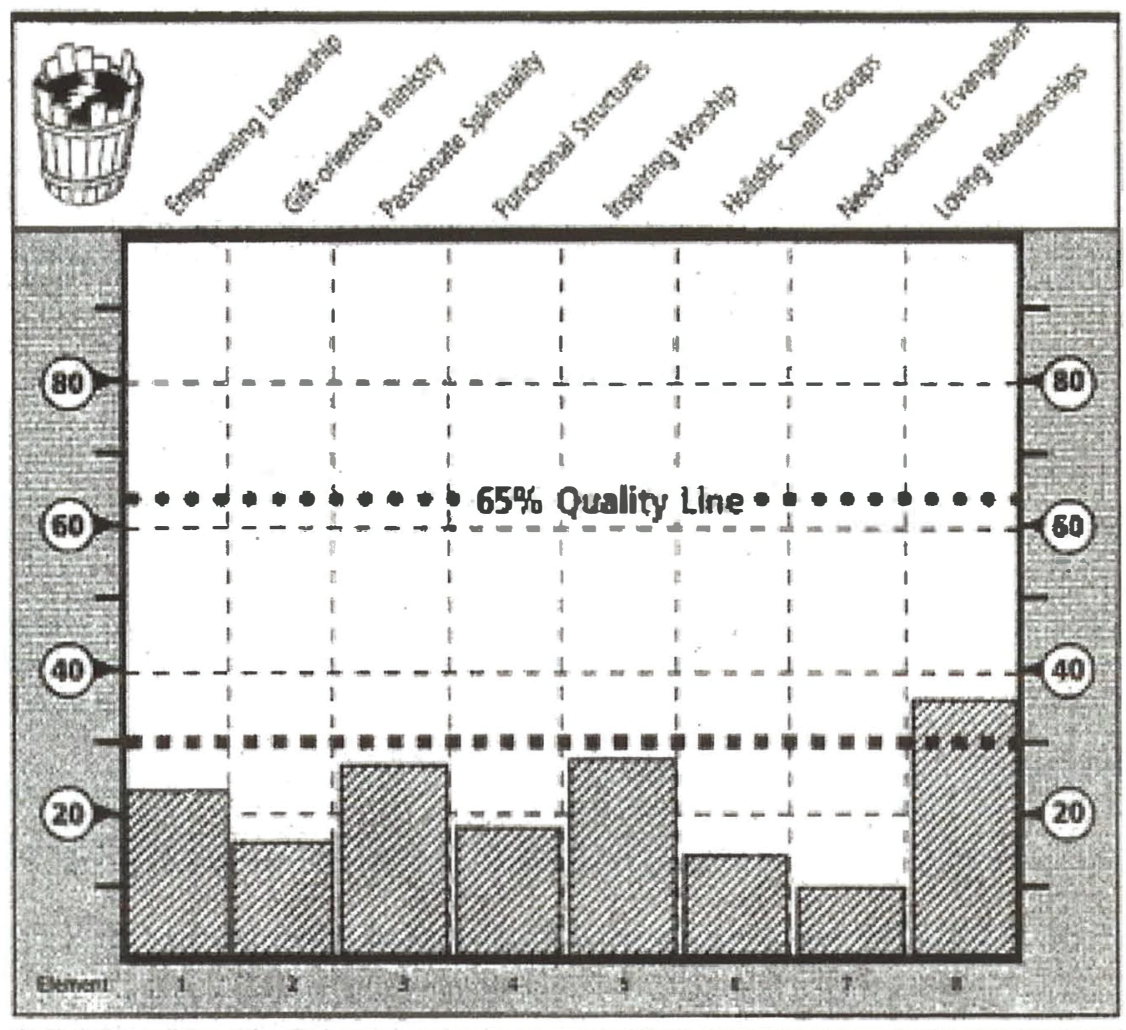

\section{Reflection Questions}

- Do these scores accarately seffect ous ministy as we know it?

- Most of our scores are below 25\%. Do we befieve outside assistarnce is nacessary?

- How could we benefit from an intenention process?

- To whom can we tum for adwice in sefecting someone to come in? 


\section{Example Church No. 4 (Rebirthing)}

When all scores fall below $10-20 \%$, the results indicate a troubled ministry that could require a church restart. Often churches must consider relocation, major leadership transition and/or closing down the ministry indefinitely. In a restart, new leadership and new methodologies are adopted which help to reposition a church's ministry.

\section{Reflection Questions}

- Do these scores accurately reflect our ministry, as we know it?

- What would our church need to do in order to turn around this non-growth trend?

- What options does our congregation have to survive this time in our history?

*The preceding charts and information is taken from Walling, Terry; Focusing Leaders, Phase One of the ReFocusing Network System; ChurchSmart Resources, Carol Stream, IL. 1998. Momentum 3.4-3.7. 